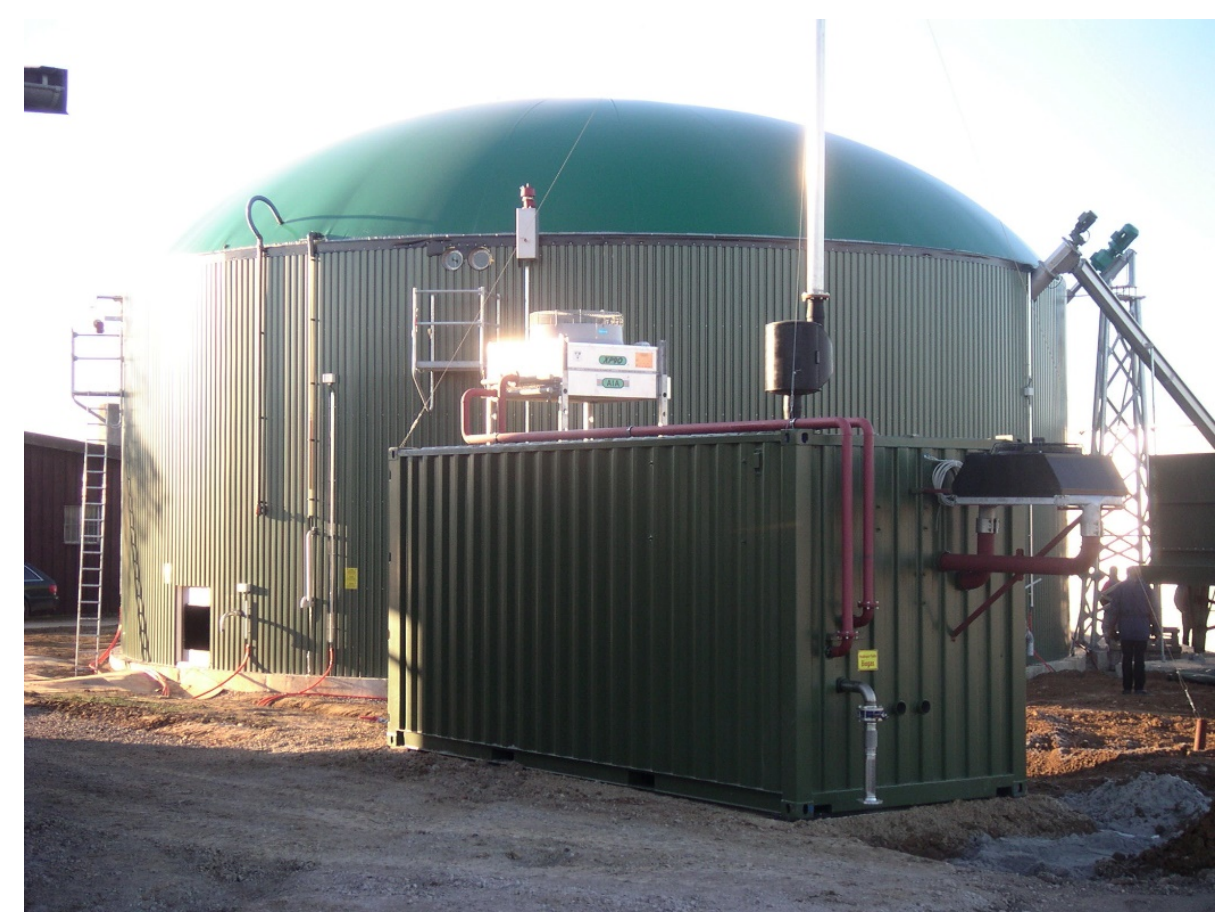

\title{
Mestvergisting als onderdeel van duurzame kringlopen
}

Auteurs:

Ciska Nienhuis ${ }^{1}$, Roland Melse ${ }^{2}$, Hanneke Heesmans ${ }^{3}$, Nico Verdoes ${ }^{2}$, Marjoleine Hanegraaf ${ }^{1}$, Izak Vermeij ${ }^{2}$ en Aart Evers $^{2}$

${ }^{1}$ Plant Research

2 Livestock Research

${ }^{3}$ Environmental Research

Wageningen, juli 2020

Rapport 840 


\section{Samenvatting}

Het ministerie van LNV wil duidelijk hebben of mestvergisting bij kan dragen aan de klimaatdoelstellingen waar de landbouw aan moet voldoen. De vraag is of mestvergisting kan bijdragen aan de reductie van broeikasgas- en ammoniakemissie, wat het (lange termijn) effect is op de organische stofopbouw en of het toevoegen van extra organisch materiaal aan de mest in de mestvergister hierop van invloed is. In deze studie is gekeken naar verschillende scenario's: rundveedrijfmest, varkensdrijfmest, beide mest typen $100 \%$ vergist en beide mest typen met covergist met organisch materiaal.

Uit de literatuur komt naar voren dat er nog weinig (veld)onderzoek gedaan is naar het verschil in effect dat mestvergisting heeft op de emissies en opbouw van organische stof in de bodem. Toedieningstechniek, (weers)omstandigheden, viscositeit van de mest en bodemcondities bepalen of mestvergisten wel of niet bijdraagt aan emissiereductie. Het wel of niet meteen afvoeren van de mest naar de vergister blijkt volgens het gebruikte vergistingsmodel het meest te bepalen of vergisting bijdraagt aan de reductie van broeikasgas- en ammoniakemissie. Monovergisting met rundveedrijfmest blijk volgens het organische stof model substantieel meer bij de dragen aan de organische stof opbouw in de bodem dan de overige meststypen.

Trefwoorden:

Digestaat

Vergister

Rundveedrijfmest

Varkensdrijfmest

Organische stof

Broeikasgas

Emissiereductie

Roth-C

(C) 2020 Wageningen, Stichting Wageningen Research, Wageningen Plant Research, Business unit Open Teelten, Postbus 430, 8200 AA Lelystad; T 03002911 11; www.wur.nl/plant-research

KvK: 09098104 te Arnhem

VAT NL no. 8113.83.696.B07

Stichting Wageningen Research. Alle rechten voorbehouden. Niets uit deze uitgave mag worden verveelvoudigd, opgeslagen in een geautomatiseerd gegevensbestand, of openbaar gemaakt, in enige vorm of op enige wijze, hetzij elektronisch, mechanisch, door fotokopieën, opnamen of enige andere manier zonder voorafgaande schriftelijke toestemming van Stichting Wageningen Research.

Stichting Wageningen Research is niet aansprakelijk voor eventuele schadelijke gevolgen die kunnen ontstaan bij gebruik van gegevens uit deze uitgave.

Rapport WPR-840

Dit onderzoek is uitgevoerd door Wageningen Plant Research, Livestock Research en Environmental Research, in opdracht van en gefinancierd door het Ministerie van Landbouw Natuur en Voedselkwaliteit in het kader van KlimaatEnvelop 2019 (BO-53-003-022).

Foto omslag: Mestvergister Open Teelten Lelystad 


\section{Inhoudsopgave}

\section{Voorwoord}

1 Inleiding

1.1 Probleemstelling

1.2 Doelstelling

1.3 Aanpak

$\begin{array}{ll}\text { Literatuurstudie } & 10\end{array}$

2.1 Het vergistingsproces 10

2.2 Productkarakteristieken van diverse soorten digestaat $\quad 10$

2.3 Emissies van broeikasgassen en ammoniak uit digestaat en mest 11

2.3.1 Emissie tijdens vergisting $\quad 12$

2.3.2 Ammoniakemissie na aanwending mest en digestaat $\quad 12$

2.3.3 Broeikasgasemissies na aanwending mest en digestaat $\quad 13$

2.4 Mogelijke effecten van digestaat en mest op de bodemkwaliteit $\quad 14$

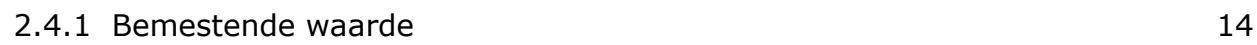

2.4.2 Aanvoer van organische stof 16

$\begin{array}{ll}2.4 .3 \text { Vochtvasthoudend vermogen } & 18\end{array}$

2.4.4 Bodemleven 18

$\begin{array}{lll}2.5 & \text { Samenvatting } & 19\end{array}$

$3 \quad$ Modelberekeningen vergisting $\quad 21$

$\begin{array}{lll}3.1 & \text { Algemeen } & 21\end{array}$

$\begin{array}{lll}3.2 & \text { Scenario's } & 21\end{array}$

$\begin{array}{lll}3.3 & \text { Uitgangspunten model } & 22\end{array}$

3.4 Resultaten van scenarioberekeningen $\quad 23$

$\begin{array}{lll}3.5 & \text { Samenvatting } & 25\end{array}$

4 Modelberekening opbouw bodem organische stof $\quad 27$

$\begin{array}{lll}4.1 & \text { Algemeen } & 27\end{array}$

$\begin{array}{lll}4.2 & \text { Beschrijving RothC model } & 27\end{array}$

4.3 Uitgangspunten voor de berekening 28

$\begin{array}{lll}4.4 & \text { Resultaten opbouw organische stof } & 29\end{array}$

$\begin{array}{lll}4.5 & \text { Samenvatting } & 31\end{array}$

$5 \quad$ Economische analyse van mono-vergisten met toevoeging van extra C 32

$\begin{array}{lll}5.1 & \text { Melkveebedrijf } & 33\end{array}$

$\begin{array}{lll}5.2 & \text { Conclusie melkveebedrijf } & 35\end{array}$

$\begin{array}{lll}5.3 \text { Vleesvarkensbedrijf } & 36\end{array}$

$\begin{array}{lll}5.4 & \text { Conclusie vleesvarkensbedrijf } & 38\end{array}$

$\begin{array}{llr}6 & \text { Beantwoording kennisvragen } & 39\end{array}$

$7 \quad$ Conclusies en aanbevelingen $\quad 41$

$\begin{array}{lr}\text { Literatuur } & 43\end{array}$

$\begin{array}{lr}\text { Bijlage 1. Samenstelling mestsoorten } & 50\end{array}$

Bijlage 2 Ammoniak emissie tijdens mesttoediening $\quad 51$ 
Bijlage 3 Overzicht veldexperimenten in Nederland met digestaat van rundveedrijfmest en varkensdrijfmest 


\section{Voorwoord}

Reductie van broeikasgasemissies is belangrijk om de klimaatdoelstellingen te halen die ervoor zorgen dat de temparatuurstijging wereldwijd binnen de perken blijft. In dit rapport is gekeken naar de bijdrage die het vergisten van mest kan leveren.

Dit onderzoek is uitgevoerd door Wageningen Plant Research, Livestock Research en Environmental Research, in opdracht van en gefinancierd door het Ministerie van Landbouw Natuur en Voedselkwaliteit in het kader van KlimaatEnvelop 2019 (BO-53-003-022).

De auteurs willen Willem van Geel en John Verhoeven van Wageningen Plant Research, en de reviewers Michel de Haan en Durk Durkz bedanken voor hun constructieve opmerkingen en suggesties. 


\section{Gebruikte afkortingen}

RDM: Rundveedrijfmest

VDM: Varkensdrijfmest

C: Koolstof (carbon), het kenmerkende element in organische verbindingen

EOS: Effectieve Organische Stof: de hoeveelheid organische stof die één jaar na toediening nog onderscheidenlijk in de bodem aanwezig is

OS: Organische Stof

N: Stikstof (nitrogen)

TOC: Total Organic Carbon

TON: Total Organic Nitrogen

$\mathrm{C} / \mathrm{N}$ : De verhouding tussen koolstof en (totale) stikstof

C/Norg: De verhouding tussen koolstof en organisch gebonden stikstof

$\mathrm{C} / \mathrm{N}_{\text {totaal }}$ : De verhouding tussen koolstof en organisch en mineraal gebonden stikstof tezamen

$\mathrm{NH}_{4}:$ Ammonium

$\mathrm{NH}_{3}$ : Ammoniak

$\mathrm{CH}_{4}$ : Methaan

$\mathrm{N}_{2} \mathrm{O}$ : Lachgas

H.C.: Humificatie coëfficient

M.C.F: Methane Conversion Factor

BMP: BioMethane Potential 


\section{Inleiding}

\subsection{Probleemstelling}

In het regeerakkoord van 2015 is afgesproken dat de bijdrage van de landbouw aan de klimaatdoelstellingen in 2030 moet zijn: een reductie van 1 Mton $\mathrm{CO}_{2}$-eq voor methaan gerelateerd aan de veehouderij, en 1,5 Mton $\mathrm{CO}_{2}$-eq voor slimmer landgebruik, o.a. tegengaan emissies uit veenweide en koolstofvastlegging in landbouwbodems. LNV wil in het licht van deze opgave helder hebben waar en hoe vergisting van mest met eventueel coproducten in het klimaat- en kringloopbeleid past met zo mogelijk een win voor de reductie van methaan en een win voor de verdringing van fossiele energie. Want, heldere beleidsdoelen stimuleren het toeleverend bedrijfsleven en de veehouders om te investeren. Vraag is of en in hoeverre vergisting van mest met eventueel coproducten kan bijdragen aan de reductie van $\mathrm{CO}_{2}$ in de atmosfeer.

Bij vergisten wordt de gemakkelijk afbreekbare koolstof (C) in mest omgezet in methaan $\left(\mathrm{CH}_{4}\right)$. Deze wordt afgevangen en gebruikt om energie op te wekken (elektriciteit na verbranding of groen gas na opwerking. De OS die in de vergister is afgebroken, is niet meer beschikbaar voor de opbouw van organische stof in de bodem. Door organische stof in de bodem op te bouwen, wordt impliciet $\mathrm{CO}_{2}$ vastgelegd in de bodem. Er vindt opbouw plaats, als er meer organische stof aan de bodem wordt toegediend dan er wordt afgebroken. Makkelijk afbreekbare koolstofverbindingen worden in het eerste jaar na toediening in de bodem (grotendeels) afgebroken, gaan als $\mathrm{CO}_{2}$ de lucht in en dragen niet of nauwelijks bij aan de $\mathrm{C}$-opbouw in de bodem en de $\mathrm{CO}_{2}$-vastlegging. Met vergisting worden de gemakkelijk afbreekbare koolstofverbindingen in eerste instantie omgezet in $\mathrm{CH}_{4}$ i.p.v. in $\mathrm{CO}_{2}$. Dus deze zou toch al niet bijdragen aan vastlegging van $C$ in de bodem.

Het digestaat dat overblijft na vergisting, bevat minder doch stabielere organische stof (OS) en wordt in de landbouw toegepast als organische mest. Alle nutriënten die met het organische materiaal de vergister ingaan (behalve een deel van de $\mathrm{C}$ die als $\mathrm{CH}_{4}$ weg gaat), komen in het digestaat terecht. De hoeveelheid digestaat die men kan aanvoeren, wordt begrensd door de mestwetgeving: de gebruiksnorm van $\mathrm{N}$-totaal uit dierlijk mest en de gebruiksnormen voor fosfaat. Bij eenzelfde aanvoer van N-totaal of fosfaat wordt daardoor met digestaat minder OS naar de bodem aangevoerd dan met de onvergiste uitgangsmest. Echter, deze OS wordt minder snel afgebroken in de bodem waardoor de OS stabieler is, waardoor er ook minder $\mathrm{CO}_{2}$ uit de bodem wordt uitgestoten. Verder is nog onbekend wat het effect op lange termijn is van de aanvoer van minder maar stabielere OS, op het OS-gehalte in de bodem.

Organische (mest)stromen zijn een belangrijke bron van organische stof en nutriëntentoevoer naar de bodem en spelen dus een belangrijke rol in de bodemvruchtbaarheid. Hoewel er op basis van de samenstelling van digestaat al veel over het effect op de bodemvruchtbaarheid gezegd kan worden (met name de chemische bodemvruchtbaarheid), is het nog onvoldoende duidelijk wat het gebruik van digestaat voor de biologische bodemvruchtbaarheid en de gewasproductie op lange termijn betekent.

Bij co-vergisten wordt minimaal 50\% dierlijke mest gemengd met andere biomassastromen (of: coproducten). Deze worden gebruikt om de gasopbrengst en daarmee het financieel rendement te verhogen. Digestaat is het restproduct dat overblijft na vergisting van biomassa en bestaat uit organische stof, opgeloste zouten, levende en dode micro-organismen en water. Het digestaat wordt volledig gezien als dierlijke mest, als bij de vergisting een of meer van de producten van bijlage Aa, onderdeel IV van de Meststoffenwet zijn gebruikt (RVO, 2019). Onder mono-vergisten verstaan we het vergisten van uitsluitend dierlijke mest. Bij deze mest mag maximaal 5\% andere biomassa worden toegevoegd (als kuilresten e.d.). Van deze variant kan in de toekomst meer gebruik worden gemaakt als meer kleine porties C (meer strogebruik, natuur inclusieve landbouw, reststromen) op agrarische bedrijven beschikbaar komen. In dit rapport beperken we ons tot de vraag hoe mono-mestvergisting van runderdrijfmest (RDM) en Varkensdrijfmest (VDM) kan bijdragen aan de kringlooplandbouw, aan de beperking van de klimaateffecten en aan opwekking van duurzame energie. 
De hoeveelheid $\mathrm{C}$ in mest is laag ten opzichte van de $\mathrm{N}$-inhoud. Voor een optimale vergisting is een hogere $\mathrm{C} / \mathrm{N}$ verhouding nodig dan de $\mathrm{C} / \mathrm{N}$ verhouding die mest bevat. $\mathrm{Er}$ is dus meer $\mathrm{C}$ nodig, om optimaal gebruik te maken van de aanwezige stikstof die de aanwezige koolstof kan vergisten. In de toekomst komt er mogelijk meer $\mathrm{C}$ op agrarische bedrijven beschikbaar voor de mono-vergisting (meer strogebruik, natuur inclusieve landbouw, reststromen). De effecten van extra $C$ uit deze producten op het vergistingsrendement en op de organische stofopbouw van de bodem zijn tevens onderwerp van deze deskstudie.

Deze studie 'Mestvergisten als onderdeel van duurzame kringlopen' is onderdeel van de Klimaatenveloppe 2019. In dit project worden de broeikasgasemissies en organische stofopbouw van digestaat in kaart gebracht en modelmatig vergeleken met andere organische stofrijke producten. Wat betreft de broeikasgassen worden gegevens meegenomen over de emissie van methaan $\left(\mathrm{CH}_{4}\right)$ bij de opslag en vergisten van mest, als ook bij de toediening van mest op het land, en over de emissie van koolstofdioxide $\left(\mathrm{CO}_{2}\right)$ en lachgas $\left(\mathrm{N}_{2} \mathrm{O}\right)$. Behalve deze broeikasgassen wordt in deze studie ook de emissie van ammoniak $\left(\mathrm{NH}_{3}\right)$ meegenomen. Door de kennis hierover te combineren, kunnen mogelijke afwenteling en kansrijke trajecten geïdentificeerd worden en ontstaat beter inzicht in de impact van maatregelen en de mate waarin zij bijdragen aan de te realiseren reductie van broeikasgasemissies.

\subsection{Doelstelling}

Doel van dit project is om vanuit wetenschappelijk beschikbare kennis een drietal vragen te beantwoorden, en daarnaast in beeld te krijgen welke benodigde kennis nog ontbreekt:

- In hoeverre draagt mono-vergisten bij aan de klimaatdoelstellingen en reductie van broeikasgas- en ammoniak emissies vanaf de bodem?

- Wat zijn de kwantitatieve effecten van vergisten op de organische stofopbouw van de bodem in relatie tot de bodembehoefte aan organische stof?

- Draagt een hogere $\mathrm{C} / \mathrm{N}$ (N-organisch) verhouding in het digestaat bij aan een verbetering van de effecten op van de klimaatdoelstellingen en broeikasgas- en ammoniak emissiereducties?

\subsection{Aanpak}

Om de kennisvragen te beantwoorden is een literatuurstudie uitgevoerd, zijn modelberekeningen gemaakt en is een technisch-economische analyse gemaakt. Centraal stond steeds de toediening van mest en digestaat (van rundvee en varkens) en de effecten op emissies en naar de bodem. Zoveel als mogelijk is aangesloten bij de huidige bemestingspraktijk, maar effecten van beweiding zijn niet meegenomen.

Voor de literatuurstudie zijn zowel wetenschappelijke papers als Nederlandse 'grijze' literatuur geraadpleegd. Ook zijn resultaten van lopende Nederlandse onderzoeksprojecten betrokken, zowel PPS-en als de andere projecten binnen de Klimaatenvelop 2018 en 2019. De volgende deelvragen komen aan de orde:

Vergistingsproces:

- Hoe groot zijn de emissies van broeikasgassen en ammoniak uit digestaat tijdens de vergisting, en bij toediening op het land, laatstgenoemde in vergelijking met onbewerkte mest?

- Leidt een verhoging van de C-inhoud door co-vergisting en/of bij mono-vergisten via bedrijfseigen producten, tot minder emissies van broeikasgasen en $\mathrm{NH}_{3}$ ?

Bodemkwaliteit:

- Wat zijn mogelijke effecten van digestaat en onbewerkte mest op de bodemkwaliteit (bemestende waarde, opbouw van organische stof, vochtvasthoudend vermogen, bodemleven) in de bodem?

- Is er een verschil in de organische stofopbouw na het toedienen van verschillende digestaten als meststoffen, waarbij extra $\mathrm{C}$ is toegediend om de $\mathrm{C} / \mathrm{N}_{\text {org }}$ ratio te verhogen? 
Technisch-economische aspecten:

- Wat zijn de technische en economische knelpunten of voordelen van een hogere C-vracht in de vergister?

De modelberekeningen betroffen een tweetal scenario-analyses, waarbij de uitgangspunten zo zijn gekozen dat deze aansloten bij de literatuurstudie. De eerste modelberekening betrof een inschatting van de emissies van ammoniak en broeikasgassen tijdens het vergistingsproces, de tweede betrof de opbouw en afbraak van organische stof in de bodem. In beide modelberekeningen werd een vergelijking gemaakt tussen mono-vergisting, vergisting met extra C-toediening, en niet-vergiste mest, voor zowel rundveedrijfmest als vleesvarkensdrijfmest en hun digestaten.

Voor de scenario-studie van het vergistingsproces is gekozen voor een productvergelijking van de volgende producten: niet vergiste mest (referentie), mono-vergiste mest (oud en vers), monovergiste mest met $5 \%$ en met $10 \%$ toevoeging van co-substraat. In deze modelstudie zijn voor deze scenario's bepaald:

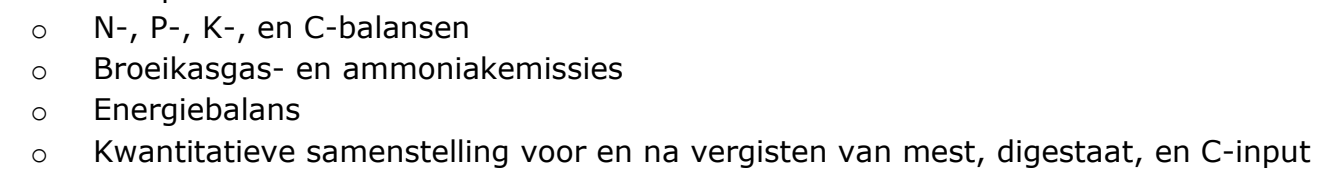

In de scenariostudie van de opbouw van organische stof in de bodem is met het model RothC berekend wat de mogelijke effecten van mest en digestaten zijn op de OS-opbouw in de bodem gedurende 100 jaar. Hierbij zijn productgegevens van o.a. de afbreekbaarheid gebruikt die beschikbaar zijn uit een eerdere studie.

Tot slot is een beknopte analyse uitgevoerd van technische en economische aspecten van monovergisten met extra toegevoegde $C$ in een vergister.

\section{Leeswijzer}

Dit rapport is als volgt opgebouwd. De literatuuranalyse staat beschreven in hoofdstuk 2, met achtereenvolgens aandacht voor het mestvergistingsproces, de opbouw van organische stof in de bodem, en ervaringen uit veldexperimenten in Nederland. Hoofdstuk 3 begint met een korte beschrijving van het model voor het vergistingsproces, waarna de resultaten van de scenario-studie worden besproken. In hoofdstuk 4 komt eerst het RothC-model aan de orde, waarna de resultaten van deze scenario-studie worden besproken. Vervolgens wordt in hoofdstuk 5 ingegaan op technische en economische aspecten. Bovengenoemde kennisvragen worden beantwoord in hoofdstuk 6. Afgesloten wordt in hoofdstuk 7 met aanbevelingen voor vervolgonderzoek en voor het beleid. 


\section{Literatuurstudie}

\subsection{Het vergistingsproces}

Digestaat is vergiste biomassa die achterblijft na de productie van biogas door bacteriën. Dierlijke mest kan hierbij de enige component zijn (mono-vergisting) maar ook in combinatie met andere soorten biomassa worden vergist (co-vergisting). Mono-vergist digestaat van dierlijke mest bestaat voor minimaal 95\% (gewicht) uit mest en voor het overige uit water en micro-organismen (zowel levend als dood). De bacteriën produceren de meeste biogas wanneer zij worden gevoed met

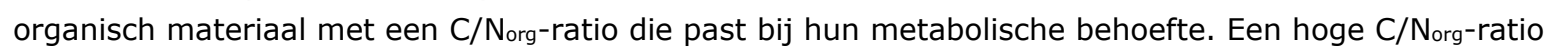
betekent dat de stikstofvoorraad uitgeput zal zijn voordat alle koolstof is verteerd. Omgekeerd betekent een lage $\mathrm{C} / \mathrm{N}_{\text {org }}$-ratio dat relatief veel $\mathrm{NH}_{4}$ kan ontstaan dat toxisch is voor de bacteriën. Runderdrijfmest heeft veelal een $\mathrm{C} /$ Norg verhouding van 17 , welke geschikt is voor anaerobe afbraak. De toevoeging van andere soorten biomassa kan hierop positief en negatief- van invloed zijn. Varkensdrijfmest veelal een $\mathrm{C} / \mathrm{N}_{\text {org }}$ verhouding van 12 , deze lagere $\mathrm{C} / \mathrm{N}$ org ratio maakt varkensmest minder geschikt is voor anaerobe afbraak. De toevoeging van biomassa met meer koolstof kan bij varkensdrijfmest dus een positievere invloed hebben. De organische stof van rundveedrijfmest is echter moeilijker afbreekbaar dan die van varkensmest (Van Geel en Van Dijk, 2013). Anderzijds is het OS-gehalte (OS per kuub mest) van RDM hoger dan dat van VDM.

Het vergistingsproces is een complex systeem van bacteriën die organisch materiaal omzetten in biogas. Relatief langzame afbraaksnelheden resulteren in lange verblijftijden in de vergister en lage doorvoersnelheden. Eventueel kan het proces worden versneld, onder andere door verkleining van invoermateriaal en/of toediening van juiste enzymen en bacteriën.

Tijdens de vergisting wordt het makkelijk afbreekbare deel van de organische stof het eerst afgebroken. Een deel van de organische gebonden mineralen verandert daardoor van samenstelling en blijft in minerale vorm in het digestaat aanwezig. Het restant is dus moeilijker afbreekbaar en bevat minder mineralen dan het uitgangsmateriaal. Het restant is stabieler en zou daardoor meer kunnen bijdragen aan de organische stof opbouw in de bodem dan het uitgangsproduct.

\subsection{Productkarakteristieken van diverse soorten digestaat}

De organische stof in digestaten is lager dan die van de onbewerkte mestsoorten, omdat een deel van de OS c.q. koolstof tijdens de vergisting wordt omgezet in methaan $\left(\mathrm{CH}_{4}\right)$. Ook de minerale samenstelling van digestaat, runderdrijfmest (RDM), varkensdrijfmest (VDM) loopt uiteen (Van Geel et al., 2019, Wolf, 2014).

Tabel 1 geeft een samenvatting en geeft de gemiddelde samenstelling van RDM, VDM en die van een aantal digestaten weer, samenstelling van individuele partijen mest varieert evenwel. Voor digestaat is die variatie nog groter, afhankelijk van de samenstelling van de uitgangsmest en de samenstelling en hoeveelheid van de toegevoegde co-vergistingsmaterialen. De aard en hoeveelheid van de OS van de ingaande producten is ook van invloed op de biogasproductie bij de vergisting en de hoeveelheid en stabiliteit van de OS in het digestaat (Van Geel en Van Dijk, 2013). 
Tabel 1 Gemiddelde samenstelling van diverse organische-mestsoorten en -reststromen (gehalten in kg/ton) voor (DS, OS, HC en EOS) Van Geel et al., 2019

\begin{tabular}{|c|cccccccc|}
\hline & $\begin{array}{c}\text { Rundvee- } \\
\text { drijfmest } \\
\text { (RDM) }\end{array}$ & $\begin{array}{c}\text { Digestaat } \\
\text { RDM 25\% } \\
\text { afbraak }\end{array}$ & $\begin{array}{c}\text { Digestaat } \\
\text { RDM 50\% } \\
\text { afbraak }\end{array}$ & $\begin{array}{c}\text { Digestaat } \\
\text { co-vergiste } \\
\text { RDM }\end{array}$ & $\begin{array}{c}\text { Vleesvarkens- } \\
\text { drijfmest (VDM) }\end{array}$ & $\begin{array}{c}\text { Digestaat } \\
\text { VDM 25\% } \\
\text { afbraak }\end{array}$ & $\begin{array}{c}\text { Digestaat } \\
\text { VDM 50\% } \\
\text { afbraak }\end{array}$ & $\begin{array}{c}\text { Digestaat } \\
\text { co-vergiste } \\
\text { VDM }\end{array}$ \\
\hline DS & 92 & 74 & 57 & 67 & 107 & 87 & 68 & 65 \\
OS & 71 & 53 & 36 & 50 & 79 & 59 & 40 & 41 \\
HC & 0,70 & 0,80 & 0,90 & 0,75 & 0,33 & 0,40 & 0,58 & 0,36 \\
EOS & 50 & 42 & 32 & 38 & 26 & 24 & 23 & 15 \\
C/N & 16,9 & 16,6 & 18,0 & 13,2 & 12,0 & 11,8 & 12,5 & 12,1 \\
EOS/DS & 540 & 573 & 568 & 560 & 244 & 271 & 341 & 227 \\
N-totaal & 4,0 & 4,0 & 4,0 & 4,0 & 7,0 & 7,0 & 7,0 & 6,1 \\
Nm & 1,9 & 2,4 & 3,0 & 2,1 & 3,7 & 4,5 & 5,4 & 4,4 \\
Nm\% & $48 \%$ & $60 \%$ & $75 \%$ & $53 \%$ & $53 \%$ & $64 \%$ & $77 \%$ & $72 \%$ \\
P2O5 & 1,5 & 1,5 & 1,5 & 1,5 & 3,9 & 3,9 & 3,9 & 3,2 \\
\hline
\end{tabular}

In vergelijking met onvergiste mest is de $\mathrm{NH}_{4}{ }^{+}: \mathrm{N}_{\text {totaal }}$ ratio in digestaat hoger, het gehalte aan OS (en C) is afgenomen en de pH is toegenomen (Möller \& Müller, 2012, Wolf, 2014, Insam et al., 2015, Risbergen et al., 2017). Een grotere hoeveelheid $\mathrm{NH}_{4}-\mathrm{N}$ in de digestaat garandeert geen verbeterde opname van stikstof, alleen bij emissiearme aanwending (wat in Nederland verplicht is) werd een significant beter effect gevonden van digestaat (Möller \& Muller, 2012), toedieningstechniek heeft een groot effect op de emissie en ook op het verschil tussen beide producten. Het aandeel $\mathrm{NH}_{4}-\mathrm{N}$ neem niet altijd toe in digestaat, dit lijkt van het stadium waarin het vergistingsproces zich bevindt af te hangen (De Boer, 2004).

Digestaat van rundveedrijfmest verkleint de directe beschikbaarheid van $\mathrm{P}$ en micronutriënten, maar dit heeft op korte termijn geen effect op de plantbeschikbaarheid onder veldcondities (Möller \& Muller, 2012). De verhouding $\mathrm{N} / \mathrm{P}_{2} \mathrm{O}_{5}$ is meestal hoger, dit is gunstig omdat er dan binnen de fosfaat gebruiksnorm meer $N$ toegediend kan worden (Van Geel en Van Dijk, 2013). De in wateroplosbare hoeveelheid fosfor $(\mathrm{P})$ (een maat voor opname van fosfor door planten) is variabel (tussen -20 en +47) (Möller \& Muller, 2012). Typische verandering in samenstelling wanneer mest vergist wordt zijn volgens de literatuur dus een hogere $\mathrm{pH}$ en een verlaagde droge stof en organische stofgehalte. De samenstelling van digestaat is naast het vergistingsproces en de aanwezige bacteriën afhankelijk van de samenstelling van de uitgangsmest en van de samenstelling en hoeveelheid van co-

vergistingsmaterialen die eventueel worden toegevoegd. De samenstelling van digestaat blijkt daarom sterk te variëren (Van Geel en Van Dijk, 2013). De meeste vaste fracties van digestaten voldoen aan de minimale Europese eisen voor organische meststof. De bemestende waarde van vloeibare digestaten liggen tussen die van dierlijke mest en minerale mest (Nkoa et al., 2014).

\subsection{Emissies van broeikasgassen en ammoniak uit digestaat en mest}

Er is veel onderzoek gedaan naar de emissies die optreden tijdens opslag en aanwending van mest en mestproducten. Het meeste onderzoek heeft zich in het verleden gericht op de emissie van $\mathrm{NH}_{3}$ en de laatste jaren is ook de emissie van broeikasgassen $\left(\mathrm{CH}_{4}, \mathrm{~N}_{2} \mathrm{O}\right)$ meer onder de aandacht gekomen. Als gevolg van het toepassen van vergisting verandert in de regel enerzijds het mestmanagement (bijv. verandering van de opslagduur van de onbewerkte mest) en anderzijds verandert de mest van samenstelling.

Onderstaand worden allereerst de emissies besproken die die optreden tijdens het vergistingsproces. Dit betreft alleen emissies van broeikasgassen; de emissie van $\mathrm{NH}_{3}$ tijdens vergisting wordt verwaarloosbaar geacht. Daarna wordt de literatuur besproken waarin aanwending van digestaat wordt vergeleken met aanwending van niet-vergiste mest met betrekking tot optredende $\mathrm{NH}_{3}-$ en $\mathrm{N}_{2} \mathrm{O}$ emissie. 


\subsubsection{Emissie tijdens vergisting}

Tijdens de vergisting kan zowel methaan ontwijken uit de vergister zelf (lekkage) als uit de opslag van het digestaat. In een recente literatuurstudie (Groenestein et al., 2020) is gekeken naar de emissie van methaan die optreedt tijdens vergisting. Daarin wordt opgemerkt dat door de diversiteit aan potentiele verliesbronnen en aan de meetmethoden die toegepast worden om de $\mathrm{CH}_{4}$-emissies uit die bronnen te meten, het bepalen van een vaste factor voor de $\mathrm{CH}_{4}$-verliezen een grote uitdaging blijft. Onderstaande kader is daaruit grotendeels overgenomen. De emissies van $\mathrm{CH}_{4}$ tijdens vergisting die in de literatuur worden genoemd lopen uiteen van $0.2 \%$ tot $15 \%$. In de modelberekeningen in hoofdstuk 3 wordt aangenomen dat het verlies gemiddeld $4 \%$ bedraagt (Hjort-Gregersen, 2014).

\section{Methaanemissie uit vergistingsinstallatie - literatuurwaarden}

Uit de beschikbare publicaties kan geconcludeerd worden dat met name open/niet gasdicht opslagen van digestaat (0,2 - 11,2\%; Liebetrau et al., 2013), overdrukventielen (0,06-3,88\%; Holmgren, 2012) en de uitlaatpunten bij WKK-installaties (0,4-3,3\%; Liebetrau et al., 2013; Zdanevitch et al., 2014) de belangrijkste $\mathrm{CH}_{4}$-verliesbronnen zijn. Scheiding van digestaat en open opslag van de gescheiden producten kunnen ook hoge $\mathrm{CH}_{4}$-verliezen $(0,13-5,04 \%$; Liebetrau et al., 2013) opleveren. Flesch et al. (2011) geven aan dat, tijdens affakkelen, ingezet wanneer de overdruk in het systeem teveel toeneemt, 10 keer hogere $\mathrm{CH}_{4}$-emissies dan tijdens normale activiteit gemeten kunnen worden. Emissies uit de vergister zelf zijn meestal verwaarlooswaar (0,02-0,07\%; Liebetrau et al., 2013; Büeler, 2011). Er zijn geen gegevens gevonden over individuele bepalingen van het $\mathrm{CH}_{4}$-verlies uit een installatie voor het opwaarderen van biogas. De gerapporteerde $\mathrm{CH}_{4}$-verliezen uit een complete vergistingsinstallatie met WKK-installatie (1,6 - 5,5\%; Flesch et al., 2011; Groth et al., 2015; Hrad et al., 2017) zijn groter dan uit een complete vergistingsinstallatie met een unit voor het opwaarderen van biogas $(0,2-0,5 \%$ voor een combinatie met gasdicht opslag van het digestaat, volgens Westerkamp et al. (2014) en Wolf en Scherello (2013); 0,6-3,0\% voor een combinatie met open opslag van het digestaat, volgens Reinelt et al., (2017). In Daniel-Gromke et al. (2015) wordt een waarde van $1 \% \mathrm{CH}_{4}$-verlies uit de gehele vergistingsinstallatie voorgesteld. In Oostenrijk wordt voor het inventariseren en rapporteren van de nationale $\mathrm{CH}_{4}$-emissies een waarde van $2 \% \mathrm{CH}_{4}$-verlies bij vergistingsinstallaties toegepast (NIR, 2016). In Martin (2008) wordt geadviseerd om een standaardwaarde van 15\% te gebruiken, terwijl in de IPCC (2006) een standaardwaarde van $10 \%$ wordt voorgesteld voor potentiele verliezen uit vergistingsinstallaties. Er zijn geen standaard studies over methaanemissie uit vergistingsinstallaties, de uitgangspunten in deze studies verschillen. Zoals in de alinea hierboven genoemd, gaan we er in deze studie vanuit dat het verlies gemiddeld $4 \%$ is.

\subsubsection{Ammoniakemissie na aanwending mest en digestaat}

Tijdens de vergisting wordt een deel van de organische stof in de mest afgebroken. Dit betekent ook dat (een deel van) de organische stikstof wordt omgezet in $\mathrm{NH}_{4}-\mathrm{N}$, dat meteen opneembaar is door planten wanneer het digestaat op het land wordt aangewend. Dit is onder meer aangetoond door Nederlands onderzoek van Rietra et al. (2015) en Houwelingen \& Gies (2017) door middel van (eenjarige) veldproeven. De $\mathrm{NH}_{3}$ emissie is echter van veel factoren afhankelijk:

Vanwege het hogere $\mathrm{NH}_{4}$ gehalte in digestaat ten opzichte van niet-vergiste mest, is het risico op vervluchtiging van $\mathrm{NH}_{3}$ en uitspoeling van nitraat groter dan bij niet-vergiste mest (PPO, 2007; Nkoa et al., 2013).

De viscositeit van digestaat is lager dan die van drijfmest. Eerstgenoemde is homogener en dunner waardoor het sneller in de bodem dringt; bijgevolg remt dit de emissie van $\mathrm{NH}_{3}$ (Wolf, 2014, Rietra et al., 2015).

Voorts heeft digestaat een hogere pH dan onbewerkte mest (Crolla et al., 2013), wat kan leiden tot hogere $\mathrm{NH}_{3}$ emissie.

De wijze van toediening speelt ook een rol. Chantigny et al. (2007) vergeleken vloeibare VDM en digestaat van VDM en vonden dat digestaat over een gemiddelde van 3 jaar 20\% minder $\mathrm{NH}_{3}$ emissie gaf dan VDM. Echter uit een eerdere studie (Chantigny et al., 2004) was geen verschil naar voren gekomen. In beide studies werden de meststoffen bovengronds 
toegediend, wat mogelijk zorgt voor een ander beeld dan de in Nederland verplichte emissiearme aanwending. Ook Risberg et al. (2017) vond geen significante verschillen tussen RDM, VDM en digestaat bij incubatie proeven met deze vier producten. Wolf (2014), onderzocht de $\mathrm{NH}_{3}$ emissie van RDM, VDM en de bijbehorende digestaten, en hun vloeibare en een vaste fractie bij toediening met een sleufkouter en inwerken na 21 uur. Er werd een hogere $\mathrm{NH}_{3}$-emissie na vergisting gevonden (zie bijlage 2). Scheiding van de drijfmest had in totaal geen effect op de emissies de vaste fractie van zowel RDM als VDM. Digestaat gaf de meeste emissie in verhouding tot de $\mathrm{NH}_{3}-\mathrm{N}$ toegediend. Ook Amon et al. (2006) laat zien dat de ammoniakuitstoot bij aanwending van digestaat met een sleufkouter hoger is (Tabel 2 in paragraaf 2.6).

Het Handboek Bodem en bemesting (www.handboekbodemenbemesting) maakt geen onderscheid in de $\mathrm{NH}_{3}$ emissie tussen mest en digestaat en gaat er voor de berekening van de $\mathrm{N}$-werkingscoëfficiënt van de stikstof in mest van uit dat $5 \%$ van de $\mathrm{NH}_{4}-\mathrm{N}$ in de mest vervluchtigt in geval van bouwlandinjectie, $20 \%$ bij bovengrondse toediening en direct inwerken van de mest en $30 \%$ bij voorjaarstoediening in wintergraan met een sleufkouter of zodenbemester.

De literatuur is dus niet altijd eenduidig met betrekking tot de emissies van $\mathrm{NH}_{3}$ uit digestaat. Er zijn meer lange termijn studies naar de emissies nodig om de effecten onder verschillende condities te bepalen. Er wordt echter aangenomen dat de $\mathrm{NH}_{3}$ emissie van digestaat hoger is dan van onvergiste mest (Gericke et al., 2009, Wolf, 2015). Het zijn vooral toedieningswijze en (weers)omstandigheden die dit bepalen. De toedieningswijze betreft hoe goed en hoe snel de mest in de grond wordt gewerkt. Injecteren in de grond geeft de minste ammmoniakvervluchtiging en bovengrondse toediening van de mest in combinatie met niet-inwerken de meeste. De vervluchtiging is relatief hoog bij zonnig weer en veel wind, terwijl er bij regenachtig weer geen of weinig emissie optreedt. Wanneer wordt aangenomen dat alleen de toedieningsmethode en de weersomstandigheden de vervluchtiging van ammoniak bepalen, dan zal die vervluchtiging bij digestaat hoger zijn dan bij onvergiste mest door het hogere aandeel $\mathrm{NH}_{4}-\mathrm{N}$ van de totale stikstof in digestaat ten opzichte van onvergiste mest. De emissie bij digestaat is mogelijk lager wanneer ook de viscositeit van de mest wordt meegenomen, omdat het digestaat dan sneller in de bodem dringt. Dit speelt een rol bij oppervlakkige of ondiepe toediening van mest, zoals met een zodenbemester, sleufkouter of sleepvoet. Mogelijk is de vervluchtiging vergelijkbaar met die van de dunne fractie van gescheiden drijfmest, maar dit moet nader worden vastgesteld middels veldonderzoek. Bij injectie wordt de mest meteen al dieper in de grond gebracht en speelt dit geen rol.

\subsubsection{Broeikasgasemissies na aanwending mest en digestaat}

\section{Lachgas}

Hoge $\mathrm{NH}_{4}-\mathrm{N}$ en makkelijk afbreekbare $\mathrm{C}$ in mest kan denitrificatie en $\mathrm{N}_{2} \mathrm{O}$ emissies in de hand werken (Wulf et al., 2002; Chantigny et al., 2010). Deze makkelijk afbreekbare C wordt afgebroken bij vergisting, en het overblijvende stabiele $C$ zou denitrificatie afremmen en dat zou resulteren in minder $\mathrm{N}_{2} \mathrm{O}$ emissie. Maar denitrificatie is ook sterk afhankelijk van bodem- en klimaatcondities, de resultaten in verschillende studies wisselen met de klimaatcondities: temperatuur, regen en humificatie coëfficiënt hebben veel invloed en zorgen ervoor dat er in het voorjaar veel denitrificatie en in het najaar weinig denitrificatie plaatsvindt.

De $\mathrm{N}_{2} \mathrm{O}$ emissie van digestaat en mest is afhankelijk van verschillende factoren, zo blijkt uit diverse onderzoeken:

Op zandgrond vonden Abubaker et al. (2013) bij aanwending van digestaat een hogere $\mathrm{N}_{2} \mathrm{O}$ emissie dan voor RDM. Op kleigrond was de $\mathrm{N}_{2} \mathrm{O}$ emissie heel laag bij RDM en ook hier was de emissie bij digestaat hoger. Op organische kleigrond gaf digestaat echter lagere $\mathrm{N}_{2} \mathrm{O}$ emissies dan RDM. De emissiepieken verschilden erg gedurende de meetperiode tussen de verschillende bodems en meststoffen. De pieken verschilden allemaal op dag 1, maar ook op een paar latere dagen (dag 6-15). Het aantal denitrificerende bacterien (het denitrificatiepotentiaal) nam significant toe op zandgrond, maar niet in de leemgrond; op kleigrond nam het denitrificatiepotentiaal alleen af bij de behandeling met RDM. 
In de studie van Chantigny et al. (2007) was op leemgrond de $\mathrm{N}_{2} \mathrm{O}$ emissie van digestaat tweederde lager ten opzichte van onbehandelde vloeibare VDM. Op lemig zand was in deze studie de $\mathrm{N}_{2} \mathrm{O}$ emissie de helft lager.

In de herfst was de emissie van digestaat wat betreft $\mathrm{N}_{2} \mathrm{O} 1,2$ maal zo hoog en voor $\mathrm{NH}_{3} 1,7$ maal zo hoog als voor runderdrijfmest (Beuning et al., 2008). Bij de eerste meting in het voorjaar werd echter geen significant verschil gevonden in dit onderzoek.

In augustus vonden Amon et al. (2006) echter dat de lachgasemissie afneemt bij aanwending van digestaat (zie Tabel 2 in paragraaf 2.6).

Op een zanderige leembodem en een ziltige kleibodem vonden Johansen et al. (2011) en Wolf (2014) respectievelijk, een hogere $\mathrm{N}_{2} \mathrm{O}$ emissie voor digestaat dan voor onbewerkte mest. Johansen et al. (2011) onderzochten RDM, digestaat van RDM en mais, digestaat van RDM en glasklaver (geen informatie over hoeveelheid bijproduct) en keken naar minerale $\mathrm{N}$, beschikbare organische $\mathrm{C}$, emissie van $\mathrm{CO}_{2}$ en $\mathrm{N}_{2} \mathrm{O}$ en microbiologische activiteiten. Het bleek dat het bemesten met digestaat 30-40\% meer emissie gaf ten opzichte van RDM.

Het lagere gehalte aan makkelijk verteerbare $\mathrm{C}$ in digestaat ten opzichte van mest kan de reden zijn voor een lagere $\mathrm{N}_{2} \mathrm{O}$-emissie (Nkoa et al., 2013, Chantigny et al., 2007). Mogelijk is digestaat daardoor een minder grote energiebron voor denitrificatie dan mest (Vallejo et al., 2006, Rochette et al., 2000).

De literatuur laat dus zowel resultaten zien waarbij de $\mathrm{N}_{2} \mathrm{O}$ toeneemt als waarbij de emissie van $\mathrm{N}_{2} \mathrm{O}$ afneemt bij gebruik van digestaat. De $\mathrm{N}_{2} \mathrm{O}$ emissie van digestaat en mest is dus afhankelijk van de grondsoort waarop, het seizoen waarin en de kwaliteit van de organische stof die het bevat.

Bovendien kan de combinatie van de verhoogde hoeveelheid $\mathrm{NH}_{4}$ en de verlaagde hoeveelheid makkelijk afbreekbare OS tot tegengestelde effecten leiden (Rietra et al., 2015). Ook de samenstelling van het digestaat in combinatie met bodemcondities en klimatologische omstandigheden bepaalt of er sprake is van een afname of toename. Mogelijk dragen ook verschillen in proefopzet en meetmethoden bij aan de gevonden verschillen. Een uniforme methode om het risico op denitrificatie te vergelijken tussen digestaat en onvergiste mest is meting van de potentiële denitrificatie onder gecontroleerde en geconditioneerde omstandigheden in een incubatieproef. Deze methode is met succes toegepast voor een vergelijking van mineralenconcentraten (Ehlert et al., 2012) en kan mogelijk ook worden ingezet bij de vergelijking van digestaat en drijfmest.

\section{Methaan}

Het aantal onderzoeken waarin gekeken is naar de emissie van methaan bij aanwending van mest en digestaat is beperkt. De aanwending heeft voor zover bekend geen invloed heeft op de productie van methaan maar het is mogelijk dat methaan(belletjes) die zich in de mest of het digestaat aanwezig zijn, vrijkomen bij aanwending. Voor uitgegist digestaat zal gelden dat zich weinig methaan meer in de vloeistof bevindt. Amon et al. (2006) vond dan ook dat de methaan uitstoot bij aanwending van digestaat lager is dan bij niet-vergiste mest (zie Tabel 2).

\subsection{Mogelijke effecten van digestaat en mest op de bodemkwaliteit}

Digestaat en mest worden in de eerste plaats ingezet in de landbouw vanwege de bemestende waarde voor het gewas en/of als bodemverbeteraar om tekorten in bodemkwaliteit op te vullen.

Bodemkwaliteit is af te leiden uit de optelsom van fysische, chemische en biologische bodemindicatoren. Wat dit betreft worden mogelijke verschillen in de effecten van digestaat en mest met name verwacht voor de bemestende waarde, verhoging van het organische stofgehalte, bijdrage aan vochtvasthoudend vermogen en bodemleven. Onderstaand komen de resultaten van het literatuuronderzoek naar genoemde aspecten aan de orde.

\subsubsection{Bemestende waarde}

Met de bemestende waarde van een meststof wordt gedoeld op de aanvoer van planten voedende stoffen. Hiervan zijn stikstof en fosfaat het meest belangrijk, en het literatuuronderzoek beperkt zich tot deze nutriënten. 
Voor stikstofbehoeftige gewassen (o.a. consumptieaardappelen, snijmais en grasland) in het voorjaar is het toepassen van digestaat een voordeel, omdat dan de snelwerkende $\mathrm{N}$ nodig is (PPO, 2007). Ook voor de biologische groententeelt is de snel vrijkomende $\mathrm{N}$ uit digestaat een voordeel (Möller \& Müller 2012).

- Vergeleken met onbewerkte mest komt eruit digestaat meer $\mathrm{NH}_{4}{ }^{+}$vrij, maar dit betekent niet dat dit er ook daadwerkelijk meer door het gewas wordt opgenomen of dat deze toename van $\mathrm{NH}_{4}{ }^{+}$zou bijdragen aan een afname van kunstmestgebruik. Uit theoretische berekeningen verwachtten Schröder et al. (2008) dat het verhoogde gehalte aan $\mathrm{NH}_{4}-\mathrm{N}$ ten opzichte van Norg tot een kleine verhoging van de stikstofwerkingscoëfficiënt kan leiden. De $\mathrm{NH}_{4}-\mathrm{N}$ komt direct beschikbaar voor de plant en het organische deel in latere jaren. In het eerste jaar na toediening lag de $\mathrm{N}$-werking, volgens berekeningen op basis van de hogere minerale $\mathrm{N}$-fractie, ongeveer $5-17 \%$ hoger ten opzichte van dierlijke mest.

Er zijn sinds 2003 verschillende veldexperimenten ingezet waarbij digestaat aan bodems is toegevoegd, vooral om het effect van de stikstofgift en gewasopbrengsten te bepalen. Tabel 14 in bijlage 3 geeft een overzicht van de veldexperimenten waarbij ook resultaten zijn gepubliceerd. Als de mestsoort niet expliciet wordt benoemd, gaan de proeven over experimenten met runderdrijfmest.

\section{Stikstofwerking grasland in Nederlandse veldexperimenten}

- In de veldproeven van Schroder et al., 2007 naar de N-werking over 5 jaar werd weinig verschil gevonden. In dit onderzoek werd van 2002 tot en met 2006 grasland bemest met o.a. RDM en digestaat. Deze auteurs stelden dat de $\mathrm{N}$-werking van digestaat op lange termijn vergelijkbaar is met die van dierlijke mest.

Digestaat en onvergiste mest werden vergeleken bij toediening op gras met zware jonge zeeklei (De Boer, 2004). De mestgiften, onvergist en vergist, waren respectievelijk 15 en 30 ton/ha, aangevuld met 2 hoeveelheden stikstofgiften uit kunstmest of drijfmest. Bij 16-18 ton/ha bleek er geen significant verschil tussen stikstoflevering van onvergiste dan wel vergiste mest. Bij 30-33 ton vergiste mest werd een significant hogere stikstofopbrengst bij de eerste snede gevonden.

- Ook uit de vergelijkingsproef van Hilhorst \& Bos (2016) bleek dat de werking van stikstof van RDM digestaat hoger ligt dan bij onvergiste mest, tot gemiddeld $23 \%$.

Water toevoegen aan het digestaat verhoogde de $\mathrm{N}$-werking ten opzichte van onverdunde digestaat tot 40\%. Houwelingen en Gies (2017) onderzochten vervolgens water verdunde digestaat op gras (op veen) en vonden dat digestaat een hogere opbrengst ( 0.3 ton droge stof gaf [ratio water digestaat 1:1]). De stikstofopname bij verdunde digestaat was 29 tot $37 \%$ hoger dan onverdunde digestaat. In deze studie werd onverdunde RDM niet onderzocht.

\section{Stikstofwerking bouwland in Nederlandse veldexperimenten}

- Er zijn verschillende onderzoeken gedaan naar de N-werking van digestaat in vergelijking met RDM. Bij 2 akkerbouwproeven met co-vergisten bleek het toedienen van digestaat 10 tot $15 \%$ hogere stikstofwerking te hebben dan onbewerkte RDM (Ovinge, 2008). Van Geel et al. (2010) rapporteerden een proef met VDM digestaat en RDM, waarbij vooral de levering van stikstof in het eerste jaar hoger was in digestaat dan in ruw VDM. De extra gewasopbrengsten werden gevonden in aardappelen ( +4 ton/ha), en snijmais ( +1.2 ton ds/ha). De opbrengst en het suikergehalte van suikerbiet waren gemiddeld over de vier proefjaren vergelijkbaar. Het is mogelijk dat positieve effecten van digestaat ten opzichte van onbewerkte mest zich alleen op de korte termijn (<4 jaar) voordoen (Schöder et al., 2007; Möller \& Müller (2012). In een vierjarige vergelijking bleek de eerstejaars $\mathrm{N}$-werking van VDM-digestaat aanmerkelijk hoger dan van onvergiste VDM (Van Geel en Van Dijk, 2013). Volgens de auteurs is de Nwerkingscoëfficiënt van $N_{\text {org }}$ afhankelijk van verschillende factoren: afbraaksnelheid van organische stof, de $\mathrm{C} / \mathrm{N}$ verhouding van organische stof, het tijdstip van toediening en de lengte van de $\mathrm{N}$-opnameperiode van het gewas.

$\mathrm{Er}$ is een (gering) verschil tussen de berekende en gemeten $\mathrm{N}$-werking van digestaat in vergelijking met die van onvergiste mest (Van Geel en Van Dijk, 2013). De auteurs schreven dit verschil toe aan verschillende processen die de $\mathrm{N}$-werking beïnvloedden. Een hoger $\mathrm{C}$ gehalte van RDM leidt ook tot een hogere $\mathrm{C} / \mathrm{N}$ verhouding en daardoor een tragere stikstof mineralisatie en latere eerstejaars $\mathrm{N}$-werking. Daarnaast wordt de organische stof van 
digestaat langzamer afgebroken, waardoor de Norg langzamer vrij komt (Van Geel et al., 2019).

Voor de hogere N-werking van vergiste RDM geeft De Boer (2014) in Van Geel en Van Dijk (2013) drie mogelijke hypotheses: 1) groeiende en weer afstervende anaerobe bacteriepopulaties, die vrijkomen door afbraak OS en afsterven na toediening digestaat; 2) vergiste mest bevat meer bacteriën en schimmels dan onvergiste mest, na toediening stimuleert dit mogelijk de afbraak van OS en mest in de bodem, 3) na toediening onvergiste mest wordt een deel van de OS snel afgebroken, waardoor bacterie populaties die $\mathrm{N}$ vastleggen snel groeien, dit komt later traag weer vrij als de gemakkelijk afbreekbare os in de bodem afneemt. Deze hypotheses zijn nog niet nader onderzocht.

- De zuurgraad van (co)vergiste mest ligt iets hoger ( $\mathrm{pH} 7.5-8$ ) dan die van onvergiste mest $(\mathrm{pH} 7)$ door omstandigheden veroorzaakte daling van de $\mathrm{pH}$ lijkt te worden gebufferd door vergiste mest. De verhouding $\mathrm{N} / \mathrm{P}_{2} \mathrm{O}_{5}$ is bij co-vergiste varkensdrijfmest wat hoger dan bij onvergiste varkensdrijfmest. Dit is in het algemeen gunstig, omdat men dan binnen de fosfaatgebruiksnorm c.q. bij gelijke fosfaatgift meer stikstof via "mest" aanvoert en minder kunstmeststikstof hoeft te gebruiken (Van Geel en Van Dijk, 2013).

- De eerstejaars $\mathrm{N}$-werking van digestaat blijkt uit de literatuur dus hoger dan dat van onvergiste mest. Het is niet duidelijk welke processen precies een rol spelen bij dit verschil in $\mathrm{N}$-werking. VDM-digestaat kan de werking van kunstmeststikstof benaderen (De Boer, 2004 in Van Geel en Van Dijk, 2013).

- Volgens Van Geel en Van Dijk (2013) is er nog nader onderzoek nodig naar de stikstofwerking van digestaat. Kennis over de stikstofwerking van belang om de juiste dosering te kunnen bepalen, opdat niet teveel en niet te weinig werkzame stikstof wordt toegediend. Zo hebben Van Geel et al. (2010) ervaren dat door een onderschatting van de stikstofwerking van digestaat bij toepassing in suikerbieten achteraf bleek dat er teveel werkzame stikstof beschikbaar kwam voor het gewas, wat nadelig is voor suikerbiet. Het leidde tot een lagere opbrengst en een lager suikergehalte.

Fosfaat

- Plan beschikbaar-P en micronutriënten van mono-vergist digestaat is lager dan van mest door de verhoogde $\mathrm{pH}$ die bij anaerobe afbraak ontstaat (Möller \& Müller, 2012).

- $\quad$ Er werd 112 dagen na incubatie van VDM en digestaat van VDM geen verschil gevonden in Pbeschikbaarheid voor de plant, in het onderzoek van Loria \& Sawjer (2005).

\subsubsection{Aanvoer van organische stof}

Organische stof wordt in de bodem afgebroken door micro-organismen, onder invloed van temperatuur en vocht. Afbraak vindt plaats van zowel het toegediende organische materiaal als van de reeds aanwezig organische stof. De bijdrage van toegediend organisch materiaal aan het organische stofgehalte in de bodem wordt uitgedrukt met het kenmerk 'effectieve organische stof' (EOS). De EOS is de hoeveelheid organische stof die 1 jaar na toediening nog onderscheidenlijk in de bodem aanwezig is. Opbouw en onderhoud van organische stof in de bouwvoor vindt plaats wanneer meer EOS aan de bodem wordt toegediend dan aan reeds aanwezige organische stof wordt afgebroken, dus bij een positieve organische stofbalans. Om de EOS van mestproducten te bepalen is in het verleden gebruik gemaakt van incubatieproeven in het laboratorium als ook van veldproeven.

In deze paragraaf worden verschillen in de afbreekbaarheid tussen digestaat en mest besproken zoals die naar voren is gekomen uit incubatieproeven in het laboratorium. De wetenschappelijk literatuur is wat dit aangaat niet eenduidig:

Het eindproduct van het vergistingsproces is in principe stabieler dan het uitgangsproduct. Verschillen in de totale afbreekbaarheid van organische stof tussen de RDM, VDM en de digestaat waren echter niet significant in een vergelijkende studie met 24 producten (Risbergen et al., 2017). Het onderzoek omvatte mono- als co-vergist digestaat van zowel RDM als VDM en betrof een incubatie van 12 dagen.

Wel werd in bovengenoemd onderzoek voor digestaat een snellere emissie van $\mathrm{CO}_{2}$ gevonden en de emissie kwam sneller tot een piek in vergelijking met drijfmest. Een vergelijkbaar resultaat werd ook gevonden door Albequerque et al. (2012) en Odlare et al. (2011). Een verklaring voor dit resultaat zou de afstervende bacterie populatie kunnen zijn waardoor er 
snel C vrijkomt. Deze verklaring wordt ook onderschreven door De Boer et al. (2014) gegeven voor N (zie paragraaf 2.5).

Door middel van een incubatieproef onderzocht De la Fuente et al. (2013) RDM en digestaat van RDM (waarvan $88 \%$ RDM en $12 \%$ mais-haver kuil). Zij vergeleken de effecten op bodem $\mathrm{C}$ - en $\mathrm{N}$-mineralisatie en vonden verschillen in de korte termijn mineralisatie. $\mathrm{Na}$ incubatie van 56 dagen was bij RDM slechts 3\% van de toegevoegde Total Organic Carbon (TOC) gemineraliseerd, tegenover $30 \%$ bij digestaat van RDM (met mais-haver).

- De grootte van de labiele C-pool blijkt een groot effect te hebben op de waarde van digestaat voor bodemvastlegging van C (Wolf, 2014). In een incubatieproef werden twee typen digestaten vergeleken met bodem organische stof en verse biomassa. De digestaat met een grote labiele organische C-pool (20\% van TOC) mineraliseerde snel in de eerste 2 weken na toediening. De grootte van de labiele C-pool speelt ook een grote rol in denitrificatie, mineralisatie van $\mathrm{N}$ en $\mathrm{N}_{2} \mathrm{O}$ emissie.

- De organische stof van co-vergiste mesten werd iets langzamer afgebroken dan die van onvergiste mesten (Van der Burgt et al., 2011). Zij schatten op basis van de resultaten de forfaitaire humificatie-coëfficiënt van RDM digestaat op 0,75 en van VDM digestaat op 0,36. Dat is voor beide mestsoorten iets hoger dan de waarde voor onvergiste mest (resp. 0,7 voor RDM en 0,33 voor VDM). De afbraaksnelheid van RDM was in de proeven consistent iets hoger dan die van RDM-digestaat. De afbraaksnelheid van VDM ten opzichte van VDM-digestaat was gemiddeld hoger.

De HC heeft betrekking op de specifieke co-vergiste mesten die in proeven zijn gebruikt. Afhankelijk van de aard en hoeveelheid van de OS in de co-vergistingsmaterialen, kan de stabiliteit c.q. HC van de OS in het digestaat variëren. Het zal daarom in geval van digestaten lastiger zijn om een eenduidige forfaitaire $\mathrm{HC}$ af te leiden dan voor onvergiste mestsoorten. Zo mogelijk moet een differentiatie worden aangebracht op basis van de materialen die de vergister in gaan.

\section{Koolstofvastlegging}

De bijdrage van organische producten aan het organische stofgehalte van de bodem kan leiden tot reductie van $\mathrm{CO}_{2}$ in de atmosfeer (=koolstofvastlegging). Dit is niet in alle situaties het geval waarbij het organische stofgehalte wordt verhoogd. De herkomst van producten is in belangrijke mate bepalend of er sprake is van koolstofvastlegging. Bij de aanwending van mest en/of digestaat van het eigen bedrijf is de koolstof tijdens de gewasgroei opgenomen uit de lucht. In dit geval is er sprake van koolstofvastlegging op bedrijfsniveau. Indien mest en/of digestaat van een ander bedrijf wordt aangevoerd, is dit niet het geval maar is er sprake van koolstofvastlegging op landelijk of regionaal niveau (afhankelijk van de herkomst van de mest). Aanvoer van organische stof producten met een stabielere OS zal resulteren in een grotere bijdrage aan het organische stofgehalte op langere termijn dan organische stof producten met een minder stabiele OS. Er zijn wettelijke regels die bepalen hoeveel $\mathrm{N}$ en $\mathrm{P}$ er toegepast mag worden per jaar, en die zo ook de mogelijke organische stof aanvoer bepalen. Het N- en P-gehalte per kilo OS is daarom een belangrijk kengetal (zie hiervoor Van Geel et al., 2019). Het kan dus zijn dat een product met een laag $C$ gehalte meer bijdraagt aan de koolstofvastlegging omdat de OS stabieler is.

\section{Opbouw organische stof in Nederlandse veldexperimenten}

Langlopende veldproeven over de bijdrage van digestaat aan de opbouw van organische stof in de bodem en koolstofvastlegging zijn nauwelijks beschikbaar voor Nederlandse klimatologische omstandigheden.

- De genoemde Nederlandse veldexperimenten zijn niet expliciet opgezet om de organische stof in de bodem na toediening van digestaat te monitoren en betroffen een relatief korte periode. Uit de beschikbare gegevens van deze veldexperimenten zijn geen conclusies te trekken over verschillen tussen digestaat en onbewerkte mest wat betreft organische stofopbouw en de bodemvruchtbaarheid op de langere termijn. In hoeverre de gemeten toename van stikstoflevering of hogere gewasopbrengsten zou kunnen leiden tot een toename van koolstof in de bodem als digestaat wordt toegepast is onvoldoende onderzocht. 
Verminderde C-aanvoer door vergisting?

Tijdens het vergistingsproces van onbewerkte RDM wordt ongeveer 25-30\% OS in de mest afgebroken en voor VDM ligt dit percentage tussen de 65-70\% (Schröder, 2016). Wanneer RDM aan de bodem wordt toegediend, dan wordt ca. 30\% in het eerste jaar afgebroken (o.a. Van Geel \& Van Dijk, 2013, Timmerman, 2006, De Boer, 2004).

Het wordt wel gesteld dat door vergisting de aanvoer van $\mathrm{C}$ naar de bodem onder druk komt te staan. Immers, een deel van het organische stof wordt omgezet in biogas en gaat dus niet naar de bodem. Insam et al. (2015) verwachten geen lange termijn negatieve effecten op bodem organische stof wanneer mest anaeroob vergist wordt. Voorbehandeling, zoals composteren of mestscheiden, kan voorts leiden tot een grotere stabiele fractie in het digestaat. Uit de review komt naar voren dat nutriëntenverliezen (in de vorm van stikstofgas) van digestaat lager zijn dan bij onvergist materiaal. Omdat er op basis van hoeveelheid $\mathrm{N}$ bemest wordt, daalt de $\mathrm{C}$ aanvoer bij bemesting met digestaat (zie Tabel 1) (Van Geel et al., 2019). Zoals in de vorige alinea is uitgelegd gaat het niet alleen om de hoeveelheid organische stof, maar ook om de stabiliteit. In hoofdstuk 4 wordt hier nader op in gegaan.

\subsubsection{Vochtvasthoudend vermogen}

Het organische stofgehalte hangt nauw samen met de bodemstructuur en watervasthoudend vermogen. Het is van groot belang voor de verkruimelbaarheid, slempgevoeligheid en bewerkbaarheid van de grond. OS zorgt voor een betere lucht- en waterhuishouding en bewerkbaarheid op kleigrond en op zandgrond zorgt OS voor een betere vochtbeschikbaarheid en een beter vasthouden van voedingsstoffen en het binden van zanddeeltjes (www.handboekbodemenbemesting).

Het organische stofgehalte speelt een grote rol bij het vochtvasthoudend vermogen van de bodem, wanneer meer organische stof aan de bodem wordt toegevoegd, verhoogt dit het vochtvasthoudend vermogen (Aduma et al., 2012). Het vochtvasthoudend vermogen van organische stof wordt bepaald door het karakter van de verbindingen (hydrofiel of juist hydrofoob) en de ordening van de ketens in bijvoorbeeld de bodemmatrix. Dit laatste zou zorgen voor de zogenoemde sponswerking van bodem organische stof. Vraag is nu of digestaat, in vergelijking met onbewerkte mest een effect heeft op het vochtvasthoudend vermogen van de bodem.

- Van digestaat is vastgesteld dat het organische componenten kan bevatten die een hydrofiele kop en een hydrofoob eind hebben. Wanneer het vochtgehalte van de bodem onder een kritiek waterpunt daalt, kunnen deze ketens ervoor zorgen dat de bodem meer vocht kunnen bevatten (Graber et al., 2009).

- Verschillen tussen digestaten zijn afhankelijk van het vocht- en/of minerale samenstelling van de bodem (Voelkner et al., 2015). In zandbodems werd een negatief effect gevonden van de toediening van digestaat op het vochtvasthoudend vermogen ten opzichte van de onbemeste referentie; in leembodems was er slechts een klein effect ten opzichte van de onbemeste referentie. Deze auteurs suggereren dat waterafstotendheid toeneemt bij indrogen van het materiaal.

Het is ook gerapporteerd dat bemesting met digestaat een positief effect had op gewasopbrengst in vergelijking met RDM, zonder dat een significante stijging van het organische stofgehalte in de bodem werd gevonden (Simon et al. (2015). Wel werden significante correlaties gevonden tussen hydrofobe bodemcomponenten en de HWC (Hot Water Extractable Carbon), wat een effect van digestaat op de kwaliteit van de bodem organische stof, in het bijzonder het vochtvasthoudend vermogen, suggereert.

\subsubsection{Bodemleven}

Dierlijke mestproducten kunnen op verschillende manieren een effect hebben op de opvang en samenstelling van het bodemvoedselweb en de biologische bodemkwaliteit.

Organische stof uit mest een voedingsbron voor het bodemvoedselweb, waarbij sommige soorten meer profiteren dan andere. Dit kan leiden tot dominantie van soorten en verstoring van het bodemevenwicht. Van rundveedrijfmest is bekend dat het de ontwikkeling van bacteriën stimuleert (Parham et al., 2002). In normale situaties zal de verandering van korte duur zijn. In extreme situaties kunnen latente ziekten tot uiting komen.

Het omgekeerde is echter ook mogelijk en de toediening van mestproducten kan een uitbraak van ziekten voorkomen. Een voorbeeld hiervan uit de VS is de onderdrukkende werking van vergiste varkensmest op het soya cysten aaltje (Xiao et al., 2007). 
- $\quad$ Een voordeel van mestbewerking (vergisten, composteren, drogen, doding van microorganismen) ten opzichte van onbwerkte mest is dat door de stabilisatie van organische stof in het product, sterke effecten op de bodembiologie worden voorkomen.

Dierlijke mest bevat micro-organismen die afkomstig zijn uit het spijsverteringskanaal van het dier. Hieronder kunnen zich soorten bevinden die (tijdelijk) overleven in de bodem en een risico op kunnen leveren voor dier- en gewasgezondheid en ook voor de mens. Over dit onderwerp is niet veel bekend; de belangstelling ervoor is groeiende.

Digestaat leidde in een potproef van Ernst et al. (2008) tot minder wormen dan dierlijke mest, maar het onderzoek van Bermejo Dominguez (2012) laat geen verschil zien. Rietra et al. (2015) concluderen op basis van hun literatuuronderzoek dat het microbieel leven minder goed gevoed wordt bij digestaat, maar dat het geen effect heeft op organische stofgehalte en voorkomen van regenwormen. Vers organisch materiaal wordt eerst afgebroken door regenwormen en in een later stadium door bacteriën en schimmels. Digestaat bevat kleinere deeltjes dan mest en hoeft niet meer afgebroken te worden door regenwormen. Hierdoor kan digestaat eerder beschikbaar zijn voor bacteriën en schimmels en zou een afname van regenwormen kunnen verklaren. Naast de omvang van de bacterie- en schimmelpopulatie is ook de onderlinge verhouding belangrijk. Tot nu toe is er weinig bekend over het effect van digestaat op de bacterie- en schimmelverhouding, ten opzichte van onvergiste mest. Het meten van bodem-biologische indicatoren is een onderdeel van veel monitoringprogramma's. Voorbeelden hiervan zijn de metabolische coëfficiënt en de respiratie. Podmirseg et al. (2019) vergeleken RDM met digestaat van RDM door incubatie van beide meststoffen en vonden geen verschil in samenstelling van schimmel en bacterie gemeenschappen, maar de basale respiratie van RDM was wel hoger dan die van het digestaat.

Bodemrespiratie is een proces dat door de meeste micro-organismen uitgevoerd wordt en geeft informatie over de activiteit van de totale microbiologische populatie. $\mathrm{NH}_{4}$-oxidatie wordt uitgevoerd door een kleine groep bacteriën die bovendien gevoelig zijn voor verstoring, en de mate waarin dit proces verloopt kan daarom informatie geven over de aanwezigheid van bijvoorbeeld toxische stoffen in de meststof. Digestaat zorgt in de regel voor een hogere $\mathrm{NH}_{4}-$ oxidatie, terwijl varkens- en rundermest aanzienlijk meer bodemrespiratieactiviteit vertonen (Risberg et al., 2006 en Nynberg et al., 2014). De effecten van digestaat zijn echter afhankelijk van de gegeven dosering en het omgekeerde kan ook voorkomen. (Nyberg et al., 2014). Vanwege de hogere gehalten aan $\mathrm{NH}_{4}$ en lagere organische stof gehalten vindt Risberg et al. (2016) digestaat beter geschikt als meststof voor zware grondsoorten zoals klei en bodems met een hoog C-gehalte en varkens- en rundermest voor lichtere zanderige gronden met weinig organische stof.

In vergelijking met onvergiste mest vergroot digestaat in de meeste gevallen waarschijnlijk de microbiologische activiteit en biomassa, dit komt naar voren in de review van Insam et al. (2015). De effecten verschillen echter per functionaliteit en/of per fylogenetische groep van bodem micro-organismen.

\subsection{Samenvatting}

De samenstelling van mest verandert door vergisting. Typische veranderingen zijn een hogere $\mathrm{pH}$ en een verlaagde droge stof- en organische stofgehalte. De N-totaal van digestaat ten opzichte van onvergiste mest bestaat meer uit minerale stikstof dan uit organische stikstof. De samenstelling van digestaat is echter sterk afhankelijk van de uitgangsmest en de co-materialen, en blijkt daarom sterk te variëren.

Tabel 2 geeft een samenvatting van de emissies van broeikasgassen en ammoniak van verschillende mestprodukten op basis van RDM. De literatuur is niet altijd eenduidig met betrekking tot de emissies van $\mathrm{NH}_{3}$ na aanwending. Verschillende factoren zijn hierop van invloed, zoals de toedieningsmethode, de weersomstandigheden tijdens en na toediening, en de viscositeit van de mest en het digestaat. Algemeen wordt aangenomen dat de $\mathrm{NH}_{3}$ emissie van digestaat hoger is dan van onvergiste mest vanwege het hoger aandeel $\mathrm{NH}_{4}-\mathrm{N}$ in digestaat dan in onvergiste mest. De emissies van $\mathrm{CH}_{4}$ tijdens vergisting lopen uiteen, van $0.2 \%$ tot $15 \%$, in de modelberekeningen in hoofdstuk 3 wordt aangenomen dat het verlies gemiddeld $4 \%$ bedraagt. De emissie van $\mathrm{NH}_{3}$ tijdens vergisting wordt 
verwaarloosbaar geacht. Ook de literatuur over $\mathrm{N}_{2} \mathrm{O}$ emissie na aanwending is niet eenduidig en vermeldt resultaten van onderzoeken waarbij de $\mathrm{N}_{2} \mathrm{O}$ emissie toeneemt maar ook afneemt bij aanwending van digestaat ten opzichte van onvergiste mest. De samenstelling van het digestaat, de bodemcondities en de klimatologische omstandigheden zijn factoren die veel invloed hebben op de emissie.

Tabel 2 Totale $\mathrm{NH}_{3}, \mathrm{CH}_{4}, \mathrm{~N}_{2} \mathrm{O}$ en $\mathrm{CO}_{2}$ emissies gedurende opslag en veldtoediening van een aantal mestprodukten op basis van runderdrijfmest (naar Amon et al. (2006).

\begin{tabular}{|c|c|c|c|c|}
\hline Mestsoort & Emissie & Opslag & Veldtoediening & Totaal \\
\hline $\begin{array}{c}\text { Onbewerkte mest } \\
\text { Gescheiden mest } \\
\text { Digestaat }\end{array}$ & $\begin{array}{c}\text { Ammoniak } \\
\left(\mathrm{g} \mathrm{NH}_{3} \text { per } \mathrm{m}^{3}\right)\end{array}$ & $\begin{array}{c}41,00 \\
39,3+287,8 \\
9,90\end{array}$ & $\begin{array}{c}185,80 \\
75,80 \\
220,0\end{array}$ & $\begin{array}{l}226,8 \\
402,9 \\
229,9\end{array}$ \\
\hline $\begin{array}{c}\text { Onbewerkte mest } \\
\text { Gescheiden mest }{ }^{1} \\
\text { Digestaat }\end{array}$ & $\begin{array}{c}\text { Methaan } \\
\left(\mathrm{g} \mathrm{CH}_{4} \text { per } \mathrm{m}^{3}\right)\end{array}$ & $\begin{array}{c}4.045,70 \\
1.833+510,6 \\
1.342,60\end{array}$ & $\begin{array}{c}1,30 \\
19,70 \\
2,00\end{array}$ & $\begin{array}{l}4.047,0 \\
2.363,3 \\
1.344,6\end{array}$ \\
\hline $\begin{array}{c}\text { Onbewerkte mest } \\
\text { Gescheiden mest } \\
\text { Digestaat }\end{array}$ & $\begin{array}{c}\text { Lachgas } \\
\left(\mathrm{g} \mathrm{N}_{2} \mathrm{O} \text { per } \mathrm{m}^{3}\right)\end{array}$ & $\begin{array}{c}20,20 \\
9+13,2 \\
28,50\end{array}$ & $\begin{array}{l}3,80 \\
6,40 \\
2,70\end{array}$ & $\begin{array}{l}24,0 \\
28,6 \\
31,2\end{array}$ \\
\hline $\begin{array}{c}\text { Onbewerkte mest } \\
\text { Gescheiden mest } \\
\text { Digestaat }\end{array}$ & $\begin{array}{l}\text { Koolstofdioxide (g } \\
\mathrm{CO}_{2} \text { per } \mathrm{m}^{3} \text { ) }\end{array}$ & $\begin{array}{c}91,21 \\
41,29+14,81 \\
37,03\end{array}$ & $\begin{array}{l}1,19 \\
2,40 \\
0,86\end{array}$ & $\begin{array}{l}92,4 \\
58,5 \\
37,89\end{array}$ \\
\hline
\end{tabular}

${ }^{1}$ Het eerste getal bij gescheiden mest is emissie van de dunne fractie, het tweede getal is de emissie van de vaste fractie.

De bemestende waarde van digestaat kan vooral op de korte termijn verschillen ten opzichte van onbewerkte mest. De eerstejaars $\mathrm{N}$-werking van digestaat blijkt veelal hoger dan van onvergiste mest. Echter de literatuur is niet eenduidig over verschillen in de mineralisatie van stikstof van mestprodukten. Dit komt voor een groot deel door de wisselende samenstellingen van de producten waarmee de verschillende onderzoeken zijn uitgevoerd. Aangenomen wordt dat op de lang termijn eventuele verschillen verwaarloosbaar zijn, aannemende dat alle stikstof beschikbaar komt.

Over de relatie tussen organische stof en vochtvasthoudend vermogen is nog maar weinig bekend. Dit geldt eens te meer voor de organische stof in digestaat. Er is nog onvoldoende onderzoek gedaan naar digestaat en vochtvasthoudend vermogen. Evenzo is er weinig literatuur beschikbaar over het effect van digestaat op bodemorganismen. In het algemeen geldt dat effecten van organische stof moeilijk onderling te ontwarren zijn, zeker in veldsituaties waarbij ook nog eens over een lange termijn moet worden gemeten.

De bevindingen uit de literatuur bieden zeker aanknopingspunten, en geven een indicatief antwoord op de drie kernvragen uit de doelstelling van deze studie. Als aanvulling op de literatuur zijn modelberekeningen gemaakt van het vergistingsproces (hoofdstuk 3 ) en van de opbouw van organische stof (hoofdstuk 4). 


\section{Modelberekeningen vergisting}

\subsection{Algemeen}

Om de effecten van mono-vergisten in beeld te brengen zijn verschillende varianten/scenario's van mono-vergisten doorgerekend met behulp van een model. In het model wordt de mest- en koolstofstromen in een stroomschema verwerkt waarbij rekening gehouden wordt met de omzetting van een deel van de koolstof naar $\mathrm{CO}_{2}$ en $\mathrm{CH}_{4}$. Met behulp van het stroomschema worden vervolgens de productie en emissie van $\mathrm{CH}_{4}$, de emissie van stikstofverbindingen $\left(\mathrm{NH}_{3}, \mathrm{~N}_{2} \mathrm{O}\right.$, $\left.\mathrm{N}_{2}\right)$ en de samenstelling van de mest en het digestaat berekend. Het model is eerder beschreven in Evers et al. (2019). In het model wordt het gehalte $\mathrm{N}$-totaal, $\mathrm{N}$-organisch, $\mathrm{N}-\mathrm{NH}_{4}{ }^{+}, \mathrm{P}_{2} \mathrm{O}_{5}$, droge stof en organische stof berekend. De $\mathrm{CH}_{4}$ productie en emissies van $\mathrm{CH}_{4}$ zijn berekend voor zover het de mest- en digestaatstromen betreft.

Het geproduceerde methaan wordt met een WKK (warmte-kracht-koppeling) omgezet in warmte en elektriciteit. De elektriciteit wordt benut als 'groene energie' ter vervanging van fossiel opgewekte elektriciteit en de warmte wordt niet benut.

Het model wordt doorgerekend voor zowel rundveedrijfmest als voor varkensdrijfmest.

\section{Rundvee}

Bij de modelberekening voor mono-vergisting van rundveedrijfmest wordt uitgegaan van een melkveebedrijf met 150 melkkoeien en bijbehorend jongvee. Er wordt weidegang toegepast, zodat ca. $21 \%$ van de mest niet in de stal terecht komt maar in de weide (melkkoeien: weidegang 156 dagen $\mathrm{x}$ 7 uur/dag; droge koeien: weidegang 9 dagen x 24 uur/dag; pinken: weidegang 155 dagen $\times 24$ uur/dag; kalveren: 114 dagen x 24 uur/dag). De drijfmestproductie bedraagt op jaarbasis ca. 5400 ton waarvan na weidegang ca. 4300 ton resteert die beschikbaar is voor vergisting. Ook de $\mathrm{CH}_{4}$ emissie als gevolg van enterische fermentatie ('herkauwers') wordt berekend.

\section{Varkens}

Tevens worden modelberekeningen uitgevoerd voor een vleesvarkensbedrijf. Uitgegaan wordt van een bedrijf met 3600 vleesvarkensplaatsen. De hoeveelheid drijfmest die geproduceerd wordt en beschikbaar is voor vergisting bedraagt ook in dit geval ca. 4300 ton/jaar bedraagt. De $\mathrm{CH}_{4}$-emissie als gevolg van enterische fermentatie wordt bij varkens buiten beschouwing gelaten (verwaarloosd).

De gehalten van de verschillende typen drijfmest worden in Tabel 5 en Tabel 7 gegeven.

\subsection{Scenario's}

Onderstaand worden de verschillende scenario's van het mestvergistingsproces nader omschreven.

Scenario 1 = referentiescenario: Opslag van mest in de put onder de stal

In het referentiesscenario wordt geen vergistingsinstallatie gebruikt maar wordt de drijfmest opgeslagen onder de stal, totdat deze wordt uitgereden. Desalniettemin zal tijdens de opslag wel enige vergisting optreden, met productie en emissie van $\mathrm{CH}_{4}\left(\right.$ en $\left.\mathrm{CO}_{2}\right)$ als gevolg. Uitgegaan wordt van een opslagcapaciteit van 6 maanden.

Scenario 2: Mono-vergisting van 'oude' mest

Bij vergisting van 'oude' mest wordt uitgegaan van opslag van drijfmest onder de stal, als in scenario 1. Na opslag wordt de mest echter niet meteen uitgereden, maar wordt de mest eerst vergist. $\mathrm{Na}$ vergisting wordt de mest alsnog uitgereden. Net als in scenario 1 wordt uitgegaan van een opslagcapaciteit onder de stal van 6 maanden. 
Scenario 3: Mono-vergisting van verse mest

Bij vergisting van verse mest wordt de drijfmest niet opgeslagen onder de stal, maar wordt de mest snel uit de stal afgevoerd. Dit kan bijvoorbeeld door een mestschuif toe te passen die enige malen per dag de mest van de stalvloer verwijdert. In de stal wordt de mest opgevangen in een kleine opvangput en van daar direct doorgeleid naar de vergistertank. Aangenomen wordt dat de verblijftijd van de mest in de stal ca. 1 week bedraagt, waardoor de methaanemissie uit de stal zelf beperkt is. $\mathrm{Na}$ vergisting van deze mest gaat het digestaat door naar een externe digestaatopslag. In deze opslag vindt enige restproductie van biogas plaats dat ontwijkt naar de atmosfeer.

\section{Scenario 4: Mono-vergisting van verse mest met bijvoeging van $5 \%$ co-substraat}

Dit scenario is grotendeels hetzelfde als scenario 3, maar het verschil is dat in dit scenario een kleine hoeveelheid co-substraat aan de te vergisten mest wordt toegevoegd. Dit co-substraat betreft organisch materiaal (bijvoorbeeld gewasresten) dat vanwege het hoge droge stofgehalte een significante verhoging van de biogasproductie tot gevolg zal kunnen hebben. Het te vergisten mengsel bestaat dan uit 95 massa\% drijfmest en 5 massa\% co-substraat.

Scenario 5: Mono-vergisting van verse mest met bijvoeging van 10\% co-substraat Dit scenario is gelijk aan scenario 4, maar in dit geval wordt niet 5 maar 10 massa\% co-substraat aan de te vergisten mest toegevoegd.

\subsection{Uitgangspunten model}

In Tabel 3 worden de belangrijkste uitgangspunten gegeven zoals die in het model gehanteerd worden voor de $\mathrm{CH}_{4}$ productie en emissie. Het model is eerder beschreven in Groenestein et al. (2020) en Evers et al. (2019).

Tabel 3 Uitgangspunten modelberekeningen productie en emissie van $\mathrm{CH}_{4}$

\begin{tabular}{|c|c|}
\hline Alle scenario's: & \\
\hline Mestopslag in stal & $\begin{array}{l}\text { - } \mathrm{CH}_{4} \text { productie is evenredig met opslagduur in stal, waarbij voor rundveemest en } \\
\text { varkensmest een } \mathrm{MCF} \text { van } 17 \% \text { resp. } 36 \%(1,2) \text { wordt aangenomen voor een } \\
\text { opslagcapaciteit van } 6 \text { maanden } \\
\text { - Alle geproduceerde } \mathrm{CH}_{4} \text { emitteert }\end{array}$ \\
\hline $\begin{array}{l}\text { Weidegang i.g.v. van } \\
\text { melkveehouderij }\end{array}$ & $\begin{array}{l}\text { - } 21 \% \text { van de geproduceerde mest komt niet in de stal terecht maar in de weide } \\
\text { - MCF in weide }=1 \%\left({ }^{3}\right) \\
\text { - Alle geproduceerde } \mathrm{CH}_{4} \text { tijdens weidegang wordt geëmitteerd }\end{array}$ \\
\hline Scenario $2 t / m$ 5: & \\
\hline Mest & - BMP bedraagt 0,22 resp. $0,31 \mathrm{~m}^{3} \mathrm{CH}_{4} / \mathrm{kg}$ OS voor rundveemest en varkensmest $\left({ }^{4}\right)$ \\
\hline Vergister & $\begin{array}{l}\text { - Aanname dat } 60 \% \text { (rundvee) resp. } 27 \% \text { (varkens) van organische stof in mest uit EOS } \\
\text { bestaat }\left({ }^{6}\right) \text {; dit betreft relatief moeilijk biologisch afbreekbaar materiaal. Aangenomen } \\
\text { wordt dat tijdens mono-vergisting voor rundveemest ca. } 30 \% \text { en voor varkensmest ca. } \\
10 \% \text { van de EOS wordt afgebroken. De overige OS, die relatief gemakkelijk afbreekbaar } \\
\text { is, wordt tijdens mono-vergisting voor ca. } 80 \% \text { afgebroken en omgezet in biogas, een } \\
\text { mengsel van } \mathrm{CH}_{4} \text { en } \mathrm{CO}_{2} \text {. } \\
\text { - } \mathrm{CH}_{4} \text { productie tot realisatie van } 96 \% \text { van de BMP van verse mest, volumeverhouding } \\
\mathrm{CH}_{4}: \mathrm{CO}_{2}=\mathrm{ca} .60: 40 \text { voor mest en ca. } 55: 45 \text { voor co-substraat } \\
\text { - Lekkage van } \mathrm{CH}_{4} \text { bedraagt } 3 \% \text { van productie }\left(^{5}\right) \\
\text { - Lekkage WKK (slip) bedraagt } 1 \% \text { van productie }\left(^{5}\right)\end{array}$ \\
\hline Digestaatopslag & $\begin{array}{l}\text { - } \mathrm{CH}_{4} \text { productie tot realisatie van } 98 \% \text { van de } \mathrm{BMP} \text { van verse mest } \\
\text { - Lekkage bedraagt } 100 \% \text { (geen gasafvang) }\end{array}$ \\
\hline
\end{tabular}

$\left({ }^{1}\right)$ Groenestein et al., 2016; $\left({ }^{2}\right)$ MCF = methane conversion factor; $\left({ }^{3}\right)$ Lagerwerf et al., 2019; $\left({ }^{4}\right)$ BMP = biomethane potential, ook wel "Bo" genoemd; $\left({ }^{5}\right)$ Totale emissie van $3 \%+1 \%=4 \%$ is gebaseerd op Hjort-Gregersen $(2014) ;\left({ }^{6}\right)$ Geel et al., 2019.

Voor de emissiereductie van $\mathrm{CO}_{2}$ die gepaard gaat met het opwekken van 'groene elektriciteit' in de WKK installatie in plaats van productie uit fossiele brandstof, wordt een factor van $721 \mathrm{~g} \mathrm{CO}_{2} / \mathrm{kWhe}$ aangenomen. Dat is de zogenaamde full scope carbon footprint waarde van grijze elektriciteit in Nederland conform de PEF datasets. Voor de productie van opgewerkt 'groen gas' ter vervanging van 
aardgas wordt een vermeden emissie van $75 \mathrm{~g} \mathrm{CO}_{2}$-eq/MJ gehanteerd. Deze $75 \mathrm{~g} \mathrm{CO}$-eq/MJ is een optelsom van $18,7 \mathrm{~g} \mathrm{CO}_{2}$-eq/MJ als carbon footprint voor de productie van aardgas en $56,50 \mathrm{~g} \mathrm{CO} / \mathrm{MJ}$ als $\mathrm{CO}_{2}$ dat vrijkomt bij de verbranding. Opgemerkt dient te worden dat de productie van biogas in een vergistingsinstallatie ook een carbon footprint kent, welke afgetrokken moet worden van de berekende emissiereductie om de netto emissiereductie te berekenen. De $\mathrm{CO}_{2}$ productie uit de $\mathrm{O}$

De belangrijkste uitgangspunten met betrekking tot de emissies van $\mathrm{NH}_{3}, \mathrm{~N}_{2} \mathrm{O}$, $\mathrm{NO}$ en $\mathrm{N}_{2}$ worden in Tabel 4 gegeven.

Tabel 4 Uitgangspunten modelberekeningen productie en emissie van $\mathrm{NH}_{3}, \mathrm{~N}_{2} \mathrm{O}$, $\mathrm{NO}$ en $\mathrm{N}_{2}$

\begin{tabular}{|c|c|}
\hline $\begin{array}{l}\text { Mestopslag in stal } \\
\text { (omzetting en emissie bij opslagcapaciteit van } 6 \\
\text { maanden, bij kortere opslag evenredig minder) }\end{array}$ & $\begin{array}{l}\text { - Omzetting } \mathrm{N} \text {-org in } \mathrm{N}-\mathrm{NH}_{4} \text { : } 10 \% \text { (Bruggen et al., 2018) } \\
\text { - Emissie } \mathrm{NH}_{3}-\mathrm{N}: 14,2 \% \text { van TAN (Bruggen et al., 2018) } \\
\text { - Emissie } \mathrm{N}_{2} \mathrm{O}-\mathrm{N}: 0,2 \% \text { van } \mathrm{N} \text {-totaal (Bruggen et al., 2018) } \\
\text { - Emissie } \mathrm{NO}-\mathrm{N}: 0,2 \% \text { van } \mathrm{N} \text {-totaal (Bruggen et al., 2018) } \\
\text { - Emissie van } \mathrm{N}_{2}: 2 \% \text { van } \mathrm{N} \text {-totaal (Vonk et al., 2018) }\end{array}$ \\
\hline Toediening dierlijke mest op grasland $\left({ }^{1}\right)$ & $\begin{array}{l}\text { - Emissie } \mathrm{NH}_{3}-\mathrm{N}: 19 \% \text { van TAN (Bruggen et al., 2018) } \\
\text { - Emissie } \mathrm{N}_{2} \mathrm{O}-\mathrm{N}: 0,9 \% \text { van } \mathrm{N} \text {-totaal (Bruggen et al., 2018) } \\
\text { - Emissie NO-N: 1,2\% van } \mathrm{N} \text {-totaal (Bruggen et al., 2018) } \\
\text { - Emissie van } \mathrm{N}_{2}: 9 \% \text { van } \mathrm{N} \text {-totaal (Vonk et al., 2018) }\end{array}$ \\
\hline $\begin{array}{l}\text { Toediening kunstmest op grasland }\left({ }^{1} \text { ) }\right. \\
\text { (aanname: kalkammonsalpeter, KAS) }\end{array}$ & $\begin{array}{l}\text { - Emissie } \mathrm{NH}_{3}-\mathrm{N}: 2,5 \% \text { van TAN (Bruggen et al., 2018) } \\
\text { - Emissie } \mathrm{N}_{2} \mathrm{O}-\mathrm{N}: 1,3 \% \text { van } \mathrm{N} \text {-totaal (Bruggen et al., 2018) } \\
\text { - Emissie NO-N: } 1,2 \% \text { van } \mathrm{N} \text {-totaal (Bruggen et al., 2018) } \\
\text { - Emissie van } \mathrm{N}_{2}: 13 \% \text { van } \mathrm{N} \text {-totaal (Vonk et al., 2018) }\end{array}$ \\
\hline
\end{tabular}

${ }^{(1)}$ Aangenomen wordt dat emissies gelijk zijn voor zowel aanwending op zandgrond, kleigrond als veengrond. De emissie van $\mathrm{N}_{2} \mathrm{O}$ op veengrond is echter ongeveer 5 keer zo hoog (Van Dijk et al., 2020) en is niet apart meegenomen in de berekeningen in dit rapport.

Zoals reeds opgemerkt wordt in het model de samenstelling van de mest en het digestaat berekend, waaronder het gehalte organische stof. Het gehalte organische stof wordt in het model opgesplitst in twee fracties: de 'moeilijk afbreekbare' organische stof' en de 'gemakkelijk afbreekbare' organische stof. Vooralsnog wordt aangenomen dat de productie van $\mathrm{CH}_{4}$ en $\mathrm{CO}_{2}$ volledig afkomstig is van gemakkelijk afbreekbare OS en niet van de moeilijk afbreekbare fractie.

\subsection{Resultaten van scenarioberekeningen}

\section{Rundvee}

In Tabel 5 worden de resultaten van de scenarioberekeningen weergegeven. De tabel laat zien wat de hoeveelheden en gehalten zijn voor mest en digestaat zoals deze na optredende aanwendingsverliezen beschikbaar zijn voor de bodem.

Uit Tabel 5 volgt dat het EOS-gehalte van het digestaat in de vergistingsscenario's lager is dan het EOS gehalte van het referentiescenario (scenario 1) waarbij geen vergisting plaatsvindt. In de scenario's waarbij co-producten worden toegevoegd (scenario 4 en 5) neemt het EOS gehalte toe als gevolg van de EOS-aanvoer die zich in de co-producten bevindt. Het gehalte van gemakkelijk afbreekbare organische stof (OS minus EOS) neemt in de vergistingsscenario's sterk af omdat deze fractie voor het grootste deel wordt omgezet in biogas.

Het gehalte minerale stikstof ( $\mathrm{N}-\mathrm{min})$ van het digestaat is aanzienlijk hoger dan van de niet vergiste mest, aangezien tijdens de vergisting een deel van de organische stof wordt afgebroken zodat de organisch gebonden stikstof ( $\mathrm{N}$-org) deels vrijkomt. Verder laat de tabel zien dat het totaal gehalte stikstof (N-tot) van het digestaat voor de scenario's waarin verse mest wordt vergist aanzienlijk hoger is dan de scenario's waarbij de mest lang in de stal blijft (scenario 1 en 2). De reden hiervoor is dat tijdens de langdurige opslag in de stal een relatief groot deel van de $\mathrm{N}$-min vervluchtigt en op die manier verloren gaat.

Tenslotte laat de tabel zien dat het fosfaatgehalte van het digestaat in principe gelijk is aan dat van de mest of iets toeneemt wanneer co-producten worden toegevoegd. Ook voor het as-gehalte geldt dat dit in principe gelijk blijft. 
Tabel 5 Resultaten modelberekeningen voor rundveedrijfmest en (co-)vergisting: massastromen en gehaltes.

\begin{tabular}{|c|c|c|c|c|c|c|}
\hline & & Scenario 1 & Scenario 2 & S cenario 3 & Scena rio 4 & Scenario 5 \\
\hline & & Referentie & Mono-vergisting & Mono-vergisting & Co-vergisting & Co-vergisting \\
\hline & & (geen vergisting) & oude mest & verse mest & $5 \% 6$ co-substraat & $10 \%$ co-substraat \\
\hline & & Mest & Digestaat & Digestaat & Digestaat & Digestaat \\
\hline \multicolumn{7}{|c|}{ Massastromen: } \\
\hline Totaal: & ton/jaar & 4319 & 4319 & 4319 & 4601 & 4914 \\
\hline os & ton/jaar & 324 & 226 & 225 & 249 & 276 \\
\hline EOS & ton/jaar & 200 & 167 & 160 & 176 & 194 \\
\hline \multicolumn{7}{|c|}{ Gehalten: } \\
\hline $\mathrm{N}-\mathrm{min}$ & $\mathrm{kg} /$ ton & 1.8 & 2.3 & 2.6 & 2.5 & 2.3 \\
\hline DS & $\mathrm{kg} /$ ton & 107.2 & 84.5 & 84.3 & 86.2 & 88.1 \\
\hline Os & $\mathrm{kg} /$ ton & 75.0 & 52.3 & 52.1 & 54.2 & 56.2 \\
\hline $\operatorname{EOS}^{*}$ & $\mathrm{~kg} /$ ton & 46.3 & 38.6 & 37.0 & 38.3 & 39.5 \\
\hline C & $\mathrm{kg} /$ ton & 35.2 & 24.6 & 24.5 & 25.5 & 26.4 \\
\hline AS & $\mathrm{kg} /$ ton & 32.2 & 32.2 & 32.2 & 32.0 & 31.9 \\
\hline
\end{tabular}

*EOS = Effectieve Organische Stof: de hoeveelheid organische stof die één jaar na toediening nog onderscheidenlijk in de bodem aanwezig is. Het model gaat uit van een verandering in de hoeveelheid EOS maar geeft geen indicatie over de stabiliteit van de organische stof.

In Tabel 6 worden de met het model berekende gasvormige emissies uit mest en digestaat weergegeven. Dit is de optelsom van de emissies die optreden in de stal, tijdens de vergisting, tijdens de opslag van het digestaat en bij aanwending van mest en digestaat. Tevens wordt vermeld welke hoeveelheid methaan wordt geproduceerd als gevolg van enterische fermentatie. Tenslotte wordt voor de vergistingsscenario's aangegeven wat de vermeden broeikasgasemissie is als gevolg van de opwekking van 'groene elektriciteit'.

Tabel 6 Resultaten modelberekeningen voor rundveedrijfmest en (co-)vergisting: emissies (BKG = broeikasgassen)

\begin{tabular}{|c|c|c|c|c|c|c|}
\hline & & Scenario 1 & Scenario 2 & Scenario 3 & Scenario 4 & Scenario 5 \\
\hline & & Referentie & Mono-vergisting & Mono-vergisting & Co-vergisting & Co-vergisting \\
\hline & & (geen vergisting) & oude mest & verse mest & $5 \%$ co-substraat & $10 \%$ co-substraat \\
\hline & & & & & $95 \%$ verse mest & $90 \%$ verse mest \\
\hline & & Mest & Digestaat & Digestaat & Digestaat & Digestaat \\
\hline $\mathrm{NH} 3$ & ton/jaar & 6.1 & 6.8 & 4.7 & 4.8 & 4.9 \\
\hline $\mathrm{CH} 4$ (enterisch) & ton/jaar & 24 & 24 & 24 & 24 & 24 \\
\hline $\mathrm{CH} 4$ (uit mest) & ton/jaar & 8.8 & 11.4 & 3.5 & 3.7 & 4.0 \\
\hline $\mathrm{N} 2 \mathrm{O}$ & ton/jaar & 0.9 & 0.8 & 0.8 & 0.8 & 0.8 \\
\hline \multirow[t]{3}{*}{ BKG totaal } & ton CO2-eq./jaar & 1067 & 1124 & 905 & 915 & 925 \\
\hline & deel enterisch & $55 \%$ & $52 \%$ & $65 \%$ & $64 \%$ & $64 \%$ \\
\hline & deel mest & $45 \%$ & $48 \%$ & $35 \%$ & $36 \%$ & $36 \%$ \\
\hline$B K G$ vermeden & ton CO2-eq./jaar & 0 & 122 & 147 & 185 & 228 \\
\hline
\end{tabular}

Uit Tabel 6 blijkt dat de $\mathrm{NH}_{3}$ en $\mathrm{CH}_{4}$-emissie afneemt wanneer de mest snel uit de stal wordt afgevoerd (scenario $3 \mathrm{t} / \mathrm{m} \mathrm{5}$ ). Wanneer oude mest wordt vergist neemt de emissie van $\mathrm{CH}_{4}$ enigszins toe omdat er enige lekkage optreedt van het de vergister geproduceerde biogas. Ditzelfde geldt voor de scenario's waarbij co-substraten worden toegevoegd (scenario 4 en 5). In deze gevallen wordt meer biogas geproduceerd waardoor ook meer $\mathrm{CH}_{4}$ door lekkage ontwijkt in vergelijking met scenario 3 . Netto wordt er in alle vergistingsscenario's wel een reductie van emissie van broeikasgassen gerealiseerd omdat er 'groene elektriciteit' wordt opgewekt. De $\mathrm{N}_{2} \mathrm{O}$ emissie is voor de verschillende scenario's (praktisch) gelijk.

\section{Varkens}

In Tabel 7 en Tabel 8 worden op vergelijkbare wijze de resultaten van de scenarioberekeningen weergegeven voor varkensdrijfmest. Ook hier (Tabel 7) zien we dat het EOS gehalte van het digestaat 
in de vergistingsscenario's lager is dan het EOS gehalte van het referentiescenario (scenario 1) waarbij geen vergisting plaatsvindt. Wel is het EOS gehalte van varkensmest aanzienlijk lager is dan bij rundvee, zowel voor de drijfmest als voor het digestaat. Ook is weer te zien dat in de scenario's waarbij co-producten worden toegevoegd (scenario 4 en 5) het EOS gehalte toeneemt als gevolg van de EOS die zich in de co-producten bevindt. Het gehalte van de gemakkelijk afbreekbare stof (OS minus EOS) neemt in de vergistingsscenario's sterk af omdat deze fractie voor het grootste deel wordt omgezet in biogas.

Tabel 7 Resultaten modelberekeningen voor vleesvarkensdrijfmest en (co-)vergisting: massastromen en gehalten

\begin{tabular}{|c|c|c|c|c|c|c|}
\hline & & Scenario 1 & Scenario 2 & Scenario 3 & Scenario 4 & Scenario 5 \\
\hline & & Referentie & Mono-vergisting & Mono-vergisting & Co-vergisting & Co-vergisting \\
\hline & & (geen vergisting) & oude mest & verse mest & 596 co-substraat & $10 \%$ co-substraat \\
\hline & & & & & $95 \%$ verse mest & $90 \%$ verse mest \\
\hline & & Mest & Digestaat & Digestaat & Digestaat & Digestaat \\
\hline \multicolumn{7}{|c|}{ Massastromen: } \\
\hline Totaal: & ton $/ \mathrm{jaar}$ & 4319 & 4319 & 4319 & 4601 & 4914 \\
\hline DS & ton $/$ jaar & 390 & 261 & 259 & 291 & 328 \\
\hline os & ton/jaar & 304 & 175 & 172 & 197 & 224 \\
\hline EOS & ton/jaar & 101 & 89 & 82 & 98 & 116 \\
\hline \multicolumn{7}{|c|}{ Gehalten: } \\
\hline $\mathrm{N}-\mathrm{min}$ & $\mathrm{kg} /$ ton & 2.0 & 2.6 & 3.0 & 2.8 & 2.7 \\
\hline $\mathrm{N}$-org & $\mathrm{kg} /$ ton & 3.0 & 2.1 & 2.3 & 2.3 & 2.4 \\
\hline $\mathrm{N}$-tot & $\mathrm{kg} /$ ton & 4.9 & 4.7 & 5.3 & 5.1 & 5.0 \\
\hline P2O5 & $\mathrm{kg} /$ ton & 3.9 & 3.9 & 3.9 & 3.8 & 3.7 \\
\hline DS & $\mathrm{kg} /$ ton & 90.3 & 60.5 & 59.9 & 63.4 & 66.7 \\
\hline os & $\mathrm{kg} /$ ton & 70.3 & 40.5 & 39.9 & 42.7 & 45.5 \\
\hline $\operatorname{EOS}^{*}$ & $\mathrm{~kg} /$ ton & 23.5 & 20.6 & 18.9 & 21.3 & 23.6 \\
\hline c & $\mathrm{kg} /$ ton & 33.1 & 19.1 & 18.8 & 20.1 & 21.4 \\
\hline AS & $\mathrm{kg} /$ ton & 20.0 & 20.0 & 20.0 & 20.6 & 21.2 \\
\hline
\end{tabular}

In Tabel 8 worden weer de met het model berekende gasvormige emissies uit mest en digestaat weergegeven. Ook hier blijkt weer dat de $\mathrm{NH}_{3}$ en $\mathrm{CH}_{4}$ emissie afneemt wanneer de mest snel uit de stal wordt afgevoerd (scenario $3 \mathrm{t} / \mathrm{m} \mathrm{5}$ ). Vergelijking van Tabel 6 en Tabel 8 leert dat de methaanproductie per ton vleesvarkensmest een stuk hoger is dan voor rundveedrijfmest. De reden hiervoor is dat de afbreekbaarheid van de OS (het deel van de OS die in biogas wordt omgezet) voor vleesvarkensmest hoger is dan voor rundveedrijfmest en dat in het model voor varkensmest een hoger OS gehalte wordt aangenomen dan voor rundveemest. Ook hier geldt weer dat er in alle vergistingsscenario's een reductie van emissie van broeikasgassen gerealiseerd omdat er 'groene elektriciteit' wordt opgewekt.

Tabel 8 Resultaten modelberekeningen voor vleesvarkensdrijfmest en (co-)vergisting: emissies (BKG = broeikasgassen)

\begin{tabular}{|c|c|c|c|c|c|c|}
\hline & & Scenario 1 & Scenario 2 & Scenario 3 & Scenario 4 & Scenario 5 \\
\hline & & Referentie & Mono-vergisting & Mono-vergisting & Co-vergisting & Co-vergisting \\
\hline & & (geen vergisting) & oude mest & verse mest & $5 \%$ co-substraat & $10 \%$ co-substraat \\
\hline & & & & & $95 \%$ verse mest & $90 \%$ verse mest \\
\hline & & Mest & Digestaat & Digestaat & Digestaat & Digestaat \\
\hline $\mathrm{NH3}$ & ton/jaar & 6.5 & 7.6 & 5.2 & 5.3 & 5.4 \\
\hline $\mathrm{CH} 4$ (uit mest) & ton/jaar & 28.1 & 31.5 & 5.7 & 5.9 & 6.2 \\
\hline $\mathrm{N} 2 \mathrm{O}$ & ton/jaar & 0.6 & 0.6 & 0.5 & 0.5 & 0.5 \\
\hline BKG totaal & ton CO2-eq./jaar & 892 & 963 & 293 & 303 & 313 \\
\hline BKG vermeden & ton CO2-eq./jaar & 0 & 142 & 223 & 261 & 304 \\
\hline
\end{tabular}

\subsection{Samenvatting}

In het model wordt aangenomen dat - naast de gemakkelijk afbreekbare organische stof - EOS tijdens vergisting voor ca. $20 \%$ wordt afgebroken. Wanneer mono-vergisting wordt toegepast is het EOS-gehalte van het digestaat dan ook lager dan het EOS-gehalte van onvergiste mest. Wanneer co- 
producten worden toegevoegd neemt in het model het OS-gehalte van het digestaat toe als gevolg van de OS die zich in de co-producten bevindt. Het model is niet geschikt om een uitspraak te doen over de afbreekbaarheid van de eindproducten van de vergisting (digestaat en/of co-digestaten). Op basis van de gekozen uitgangspunten laten de berekeningen in het model zien dat het gehalte minerale stikstof ( $\mathrm{N}$-min) van het digestaat aanzienlijk hoger is dan van onvergiste mest.

Wanneer de mest snel uit de stal wordt afgevoerd (om naar de vergister gepompt te worden) neemt de emissie van $\mathrm{NH}_{3}$ en $\mathrm{CH}_{4}$ sterk af. Daarnaast treedt er een reductie van de emissie van broeikasgassen op omdat er 'groene elektriciteit' wordt opgewekt. De $\mathrm{N}_{2} \mathrm{O}$-emissie is voor de verschillende scenario's (praktisch) gelijk. 


\section{Modelberekening opbouw bodem organische stof}

\subsection{Algemeen}

Organische meststoffen zijn bij uitstek geschikt om, bij regelmatig gebruik, te zorgen voor evenwicht op de organische stofbalans en in voorkomende gevallen het gehalte te verhogen. Eén van de kernvragen van deze studie is of digestaat kan leiden tot meer, of snellere opbouw van bodem organischestof dan onbewerkte mest, en of - er wat dit aangaat - sprake is van relevante verschillen tussen digestaten (mest van verschillende diersoorten; mono- en co-vergisting). Inzicht in de opbouw en afbraak van organische stof in de bodem kan worden verkregen met organische stof modellen. Hierbij kan onderscheid worden gemaakt in korte en lange termijn modellen. Voor deze studie is voor het RothC model gekozen dat heel geschikt is voor de middellange periode waarover inzicht is gewenst, namelijk een termijn van 100 jaar, waarin de effecten van het agrarisch handelen op de bodemorganische stof meetbaar worden maar waarschijnlijk nog niet onomkeerbaar zijn.

\subsection{Beschrijving RothC model}

RothC-26.3 is een compartimenten-model voor de omzetting van organische koolstof in niet met water verzadigde bodems. Het model maakt gebruik van gewone differentiaalvergelijkingen, rekent in tijdstappen van één maand en geeft als output de totale voorraad organisch koolstof (ton ha-1), de microbiële biomassa koolstof (ton ha-1) en $\Delta$ 14C (voor de berekening van de radioactieve leeftijd), over een periode van één jaar tot honderden jaren. De volgende factoren zijn in het model van invloed: kleigehalte, gemiddelde temperatuur, gemiddeld bodemvochttekort en het al dan niet bedekt zijn van de bodem. Organische stof wordt met 1e orde snelheid afgebroken. Standaard wordt met een bodemlaag van $23 \mathrm{~cm}$ gerekend, maar dit kan worden aangepast.

Het model heeft vijf compartimenten (C-pools) waarvan twee voor de aanvoer van koolstof uit gewasresten en organische meststoffen, en drie voor de bodem C-pools:

DPM = Decomposable plant material (Afbreekbaar)

RPM = Resistant plant material (Traag afbreekbaar)

BIO = Biomassa (Snel afbreekbaar)

HUM = Gehumificeerd organisch materiaal (Moeilijk afbreekbaar)

IOM = Inert organisch materiaal

Het model gaat uit van elkaar opvolgende omzettingen. In elke volgende stap wordt de dan aanwezige organische stof, bijvoorbeeld RPM, omgezet in drie fracties met verschillende afbreekbaarheid $\left(\mathrm{CO}_{2}\right.$, BIO en HUM). 


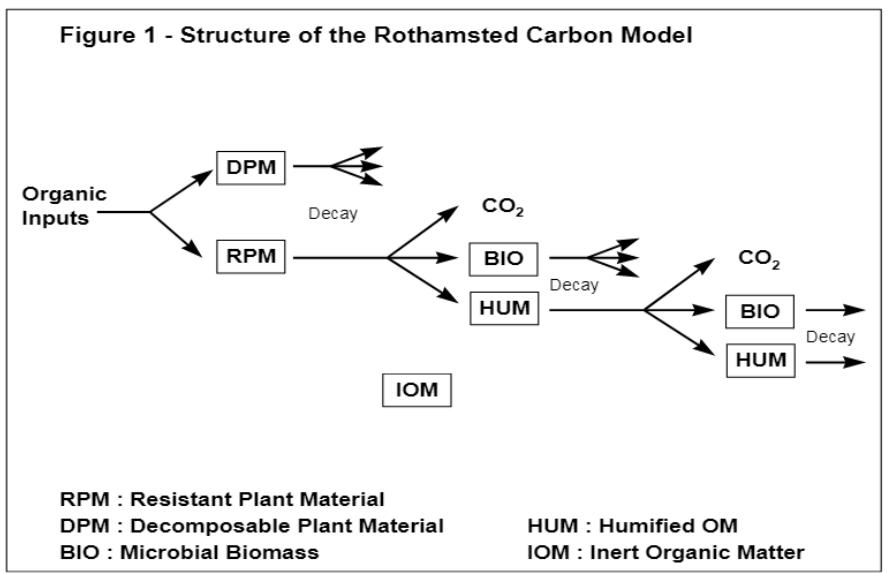

Figuur 1 Structuur van het RothC model (Coleman \& Jenkinson, 2014)

Het model houdt verschillende waarden voor de DPM/RPM ratio aan in relatie tot landgebruik, bijvoorbeeld 1,44 voor verbeterd grasland en 0,67 voor matige graslanden en savannes. Voor de aanvoer van organische meststoffen zoals compost is de DPM/RPM-ratio te berekenen met een empirische formule van de Universiteit van Gent (Anoniem, 2008) op basis van de humificatiecoëfficiënt $(H C)$.

DPM/RPM-ratio $=-2,174 \times \mathrm{HC}+2,02$

$(\mathrm{HC}<0,92 ;$ indien $\mathrm{HC}>0$, geldt DPM/RPM $=0)$

Het RothC-model is ontwikkeld en gevalideerd aan bodems van de lang-termijn experimenten van Rothamsted in Zuidoost Engeland. Het bredere gebruik is getoetst aan de hand van de GMP-criteria en akkoord bevonden (Zwart, 2001) voor begraasde ecosystemen in verschillende klimaatzones, akkerbouw ecosystemen in verschillende klimaatzones en natuurlijk en bosbouwecosystemen in koele gematigde klimaten.

\subsection{Uitgangspunten voor de berekening}

Doel van de berekeningen is om de koolstofvastlegging door toediening van digestaat te kunnen vergelijken met die door andere mestprodukten. Startpunt is de keuze van invoergegevens voor de scenarioberekeningen. Om onderscheid tussen digestaat, mest en co-vergist product te kunnen maken is een dataset nodig met kwaliteitskenmerken van de verschillende producten. Naast de hoeveelheid aan te voeren product, zijn het $\mathrm{C}$-gehalte, de humificatie-coëfficiënt en het $\mathrm{N}$-gehalte belangrijke variabelen. Bij co-vergisting spelen ook de hoeveelheid en kenmerken van de toegevoegde materialen een rol. Het vergistingsmodel maakt beperkt onderscheid in de stabiliteit van de eindprodukten op basis van produktkarakteristieken. Daarom is ervoor gekozen om bij de RothC-berekeningen gebruik te maken van gegevens van Van Geel et al. (2019). De scenario's zijn voor het overige vergelijkbaar met de scenario's die zijn doorgerekend met het mestvergistingsmodel: onderscheid is gemaakt in onbewerkte mest, mono-vergistte mest en co-vergistte mest, uitgaande van zowel runder- als varkensmest, dus 6 scenario's in totaal.

Bij de berekeningen is uitgegaan van de huidige bemestingspraktijk, dat wil zeggen een jaarlijkse toediening van deze meststoffen op basis van $170 \mathrm{~kg} \mathrm{~N}$-totaal per ha. Opgemerkt zij dat, voor derogatiebedrijven, vaak $250 \mathrm{~kg} \mathrm{~N}$-totaal per ha wordt toegediend. Het maakt voor de uiteindelijke prioritering van de mestprodukten niet uit van welke hoeveelheid wordt uitgegaan, mits deze hoeveelheid voor de mestprodukten gelijk is. De voor het RothC-model benodigde C-aanvoer in ton per ha is berekend uit 170 / N-totaal gehalte * C-totaal gehalte / 1000. Gegevens over de humificatiecoëfficiënten zijn met de formule van het onderzoek uit Gent (zie vorige paragraaf) omgerekend naar DPM/RPM-ratio. Voor de N-gehalten, humificatie-coëfficiënten en overige kenmerken van de meststoffen is gebruik gemaakt van de gegevens uit Van Geel et al. (2019). De berekeningen zijn gemaakt over een periode van 100 jaar. In het RothC model zijn de overige condities constant 
gehouden (bijvoorbeeld temperatuur: jaargemiddelde $=9^{\circ} \mathrm{C}$ en vocht: $\mathrm{pF}=2,0$ ). Een overzicht van de kenmerken van de zes meststoffen is opgenomen in Tabel 9.

Tabel 9 Invoergegevens voor de modelberekeningen met RothC

\begin{tabular}{|c|c|c|c|c|c|c|c|}
\hline 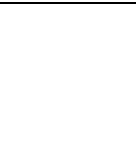 & 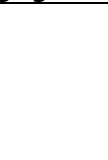 & $\begin{array}{c}\text { Scenario } 1 \\
\text { RDM } \\
\text { Mest }\end{array}$ & $\begin{array}{c}\text { Scenario } 2 \\
\text { RDM mono- }^{2} \text { vergist }^{1} \\
\text { Digestaat }\end{array}$ & $\begin{array}{c}\text { Scenario } 3 \\
\text { RDM co- } \\
\text { vergist } \\
\text { Digestaat }\end{array}$ & $\begin{array}{c}\text { Scenario } 4 \\
\text { VDM } \\
\text { Mest }\end{array}$ & $\begin{array}{c}\text { Scenario } 5 \\
\text { VDM mono- } \\
{\text { vergist }{ }^{1}}^{\text {Digestaat }}\end{array}$ & $\begin{array}{c}\text { Scenario } 6 \\
\text { VDM co- } \\
\text { vergist } \\
\text { Digestaat }\end{array}$ \\
\hline \multicolumn{8}{|l|}{ Gehalten: } \\
\hline DS & $\mathrm{kg} /$ ton & 92 & 57 & 67 & 107 & 68 & 65 \\
\hline OS & $\mathrm{kg} /$ ton & 71 & 36 & 50 & 79 & 40 & 41 \\
\hline C-tot & kg/ton & 36 & 18 & 25 & 40 & 20 & 21 \\
\hline & & 0,70 & 0,90 & 0,75 & 0,33 & 0,58 & 0,36 \\
\hline $\begin{array}{l}\mathrm{DPIM} / \mathrm{RPI} \text { } \\
\text { ratio }\end{array}$ & & 0,50 & 0,06 & 0,39 & 1,30 & 0,76 & 1,24 \\
\hline $\mathrm{N}$-tot & $\mathrm{kg} /$ ton & 4,0 & 4,0 & 4,0 & 7,0 & 7,0 & 6,1 \\
\hline $\mathrm{N}$-org & $\mathrm{kg} /$ ton & 2,1 & 1,0 & 1,9 & 3,3 & 1,6 & 1,7 \\
\hline $\mathrm{C} / \mathrm{N}$-org & & 16,9 & 18,0 & 13,2 & 12,0 & 12,5 & 12,1 \\
\hline \multicolumn{8}{|l|}{ Aanvoer: } \\
\hline produkt & ton/ha & 42,5 & 42,5 & 42,5 & 24,3 & 24,3 & 27,9 \\
\hline C-tot & ton/ha & 1,5 & 0,8 & 1,1 & 1,0 & 0,5 & 0,6 \\
\hline
\end{tabular}

${ }^{1}$ ) variant $50 \% \mathrm{~N}$-mineralisatie

Tabel 9 laat zien dat voor de zes meststoffen de HC uiteen loopt van 0,33 (VDM) tot 0,90 (RDM monovergist) en het $\mathrm{N}$-totaal gehalte van 4,0 (RDM en beide RDM digestaten) tot 7,0 (VDM en monovergist VDM). De tabel geeft ook informatie over het $\mathrm{N}_{\text {org }}$ gehalte van de meststoffen en de $\mathrm{C} / \mathrm{N}$-org ratio. Deze twee kengetallen worden niet gebruikt voor de RothC-berekeningen. Ze zijn toch opgenomen in de tabel omdat ze inzicht kunnen geven in de gevonden verschillen tussen producten.

\subsection{Resultaten opbouw organische stof}

\section{Rundvee}

Figuur 2 geeft de resultaten van de modelberekeningen met de RDM produkten De berekende Copbouw voor de RDM producten liep uiteen van 21 ton $C$ per ha voor co-vergist digestaat tot 77 ton $C$ per ha voor mono-vergist digestaat.

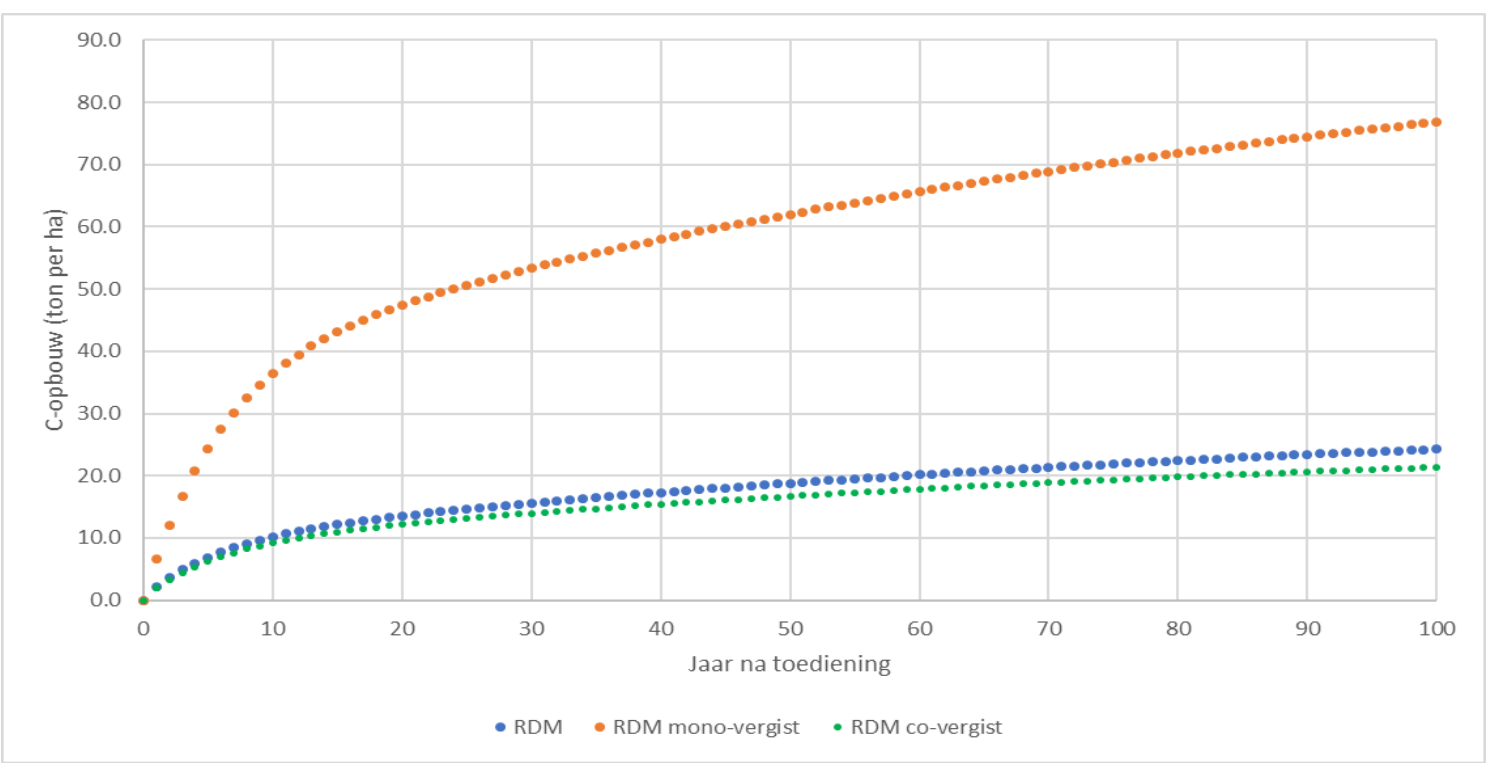

Figuur 2 Vergelijking van de C-opbouw van digestaat (mono-en co-vergist) met niet-vergistte mest, uitgaande van rundermest. 
De berekende toediening was in tonnage product voor de drie producten gelijk, door de berekeningswijze op basis van $170 \mathrm{~kg} \mathrm{~N}$ per ha en een gelijk N-gehalte (42,5 ton per ha, Tabel 9). Vanwege verschillen in het C-gehalte liep de C-aanvoer uiteen van 0,8 ton per ha voor mono-digestaat tot 1,5 voor onbewerkte mest. De hoge C-opbouw van mono-digestaat moet dan ook geheel worden toegeschreven aan de hogere humificatie-coëfficiënt $(0,90)$ van dit product in vergelijking met die van co-vergist digestaat en onbewerkte mest $(0,75$ respectievelijk 0,70$)$.

Opvallend in Figuur 2 is het sterk stijgende verloop van de curve voor mono-vergist RDM in vergelijking met zowel RDM en co-vergist RDM. De cijfers uit tabel 9 geven de verklaring. Vanuit de humificatie-coëfficiënt volgt de DPM/RPM ratio, deze is bij $\operatorname{RDM}(0,50)$ hoger dan die van RDM covergist $(0,39)$. Eenzelfde jaarlijkse C-aanvoer bij zowel RDM als RDM co-vergist zou RDM co-vergist een hogere C-opbouw te zien geven. Echter, RDM co-vergist heeft een lager C-gehalte waardoor bij gelijke jaarlijkse toepassing ( $\mathrm{N}$-totaal gehalte is gelijk voor RDM en RDM co-vergist) de C-opbouw uiteindelijk nagenoeg gelijk is. Het volgende voorbeeld kan dit verduidelijken:

- Voor RDM en mono-vergist RDM is het $\mathrm{N}$-totaal gehalte 4,0 kg per ton. Uitgaande van $170 \mathrm{~kg}$ Ntot per ha, is de aanvoer van beide producten gelijk, namelijk 42,5 ton per ha.

- Het C-gehalte van mono-vergist RDM is de helft van RDM (36 kg per ton voor RDM en $18 \mathrm{~kg}$ per ton voor mono-vergist RDM), reden waarom de C-aanvoer van mono-vergist RDM slechts de helft is van die van RDM.

- De HC van mono-vergist RDM is echter met 0,90 aanzienlijk hoger dan de 0,70 van RDM, leidend tot een veel lagere DPM/RPM ratio $(0,06$ resp. 0,50).

De hogere $\mathrm{HC}$, dus de grotere stabiliteit van mono-vergist RDM, is de reden dat de C-opbouw veel sneller verloopt dan van beide andere producten, zelfs als is de C-aanvoer lager.

\section{Varkens}

Figuur 3 geeft de resultaten van de modelberekeningen met de varkensmestprodukten. Merk op dat de schaling van de $\mathrm{Y}$-as lager is dan in bovenstaande figuur 2. In tegenstelling tot de RDM-producten, wordt de hoogste C-opbouw voor de varkensmestproducten niet bereikt met een digestaat, maar met onbewerkte mest. De berekende C-opbouw voor de varkensmestproducten liep uiteen van 5,5 ton C per ha voor co-vergist digestaat tot 9,0 ton $C$ per ha voor onbewerkte mest.

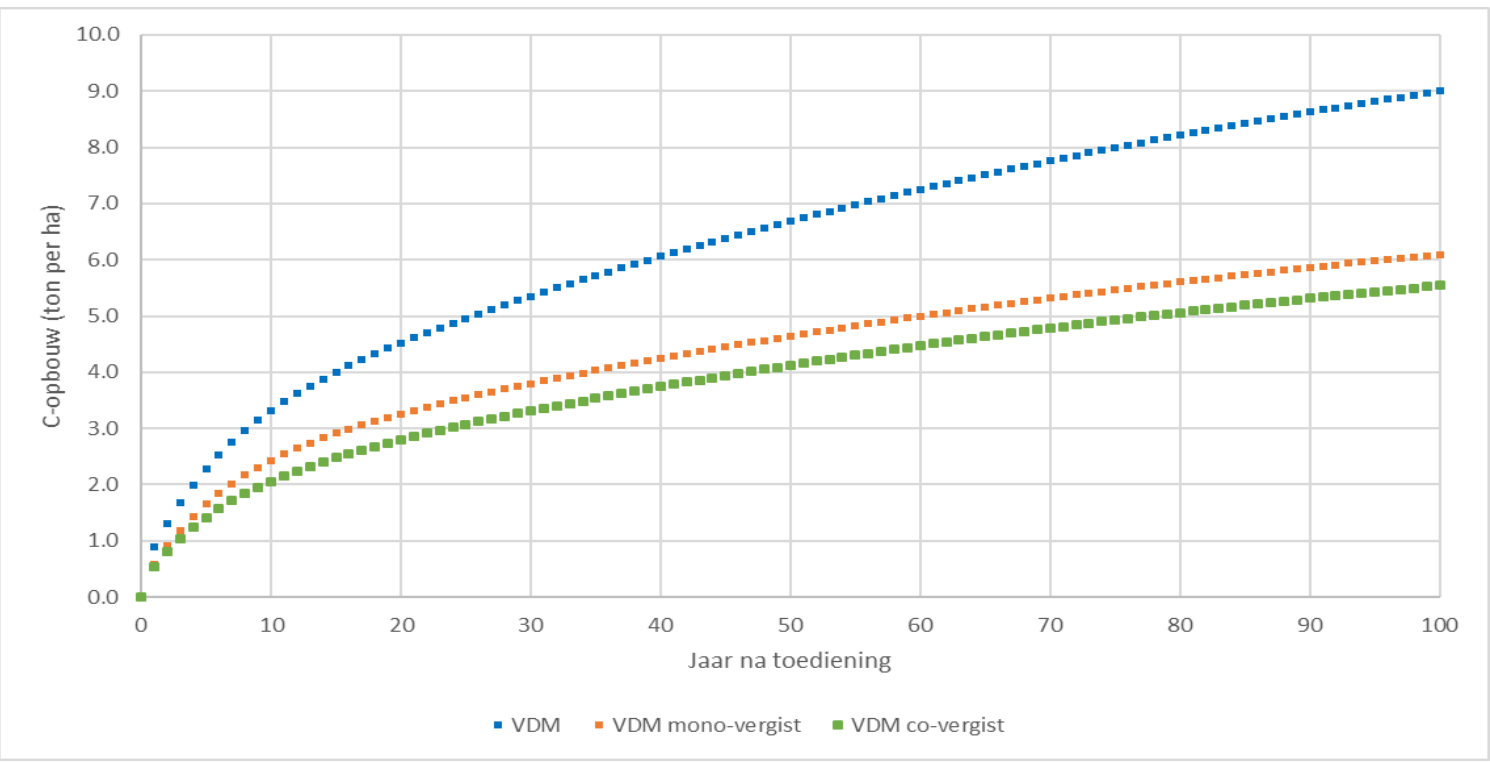

Figuur 3 Vergelijking van de C-opbouw van digestaat (mono-en co-vergist) met niet-vergistte mest, uitgaande van varkensmest

Figuur 3 laat voorts zien dat het verschil in de C-opbouw tussen mono- en co-vergist digestaat van varkensmest relatief gering is, waarbij co-vergist digestaat de iets lagere C-opbouw laat zien (5,5 ton $\mathrm{C}$ per ha). Dit is in overeenstemming met de lagere humificatie-coëfficiënt van VDM co-vergist 
digestaat $(0,36$ om 0,58$)$. De C-opbouw van co-vergist VDM digestaat is pakweg een kwart van die voor co-vergistte RDM.

De DPM/RPM ratio van VDM mono-vergist $(0,76)$ is een stuk lager dan van VDM co-vergist $(1,24)$. Bij gelijke $\mathrm{N}$-totaal toepassing per ha vindt bij VDM co-vergist iets meer $\mathrm{C}$ per ha toepassing per ha plaats. Uiteindelijk levert dit een C-opbouw op waarbij het effect van de DPM/RPM ratio van VDM mono-vergist ervoor zorgt dat de C-opbouw net iets boven die van VDM co-vergist ligt.

De DPM/RPM ratio van VDM ligt met 1,30 boven die van zowel VDM mono-vergist $(0,76)$ als VDM covergist $(1,24)$. Het verschil tussen de DPM/RPM ratio van VDM en VDM co-vergist is het kleinst maar bij gelijke $\mathrm{N}$-totaal per ha toepassing per jaar vindt een veel grotere hoeveelheid $\mathrm{C}$ per ha toegepast plaats, waardoor de C-opbouw veel hoger ligt.

Opmerkelijk zijn de verschillen tussen Figuur 2 en Figuur 3 wat betreft de berekende C-opbouw. Verreweg de hoogste opbouw is berekend voor RDM mono-vergist digestaat. Dit resultaat komt voort uit een combinatie van de factoren $\mathrm{N}$-totaal gehalte, C-totaal gehalte en $\mathrm{HC}$ en het nemen van de $\mathrm{N}$ aanvoer als uitgangspunt. De modelberekeningen laten dus zien dat, hoewel er tijdens het vergistingsproces organische stof verdwijnt, het in principe mogelijk is om een product te verkrijgen dat meer dan onbewerkte mest het organische stofgehalte van de bodem verhoogt.

De berekende uitkomsten laten zien dat de $\mathrm{HC}$ en dus de DPM/RPM-ratio van het toegediende product een belangrijke rol spelen bij koolstofvastlegging. Hoe lager de DPM/RPM-ratio, hoe hoger de koolstofvastlegging. De DPM/RPM-ratio is berekend uit de humificatie-coëfficiënt. De relatie tussen deze twee variabelen is dusdanig dat, in het traject tot $\mathrm{HC}=0,92$, een klein verschil in humificatiecoëfficiënt een groot effect heeft op de DPM/RPM-ratio. Deze relatie is afgeleid van een beperkt aantal meetgegevens. Een betrouwbare bepaling van de $\mathrm{HC}$ is in ieder geval een vereiste voor het maken van een goede vergelijking tussen mestproducten. Gegevens uit diverse onderzoeken laten een grote spreiding zien in HC waarden van mest en mestproducten. Van Geel et al. (2019) noemen als voorbeeld de bandbreedte voor de HC van RDM, die 0,4 - 0,9 bedraagt. Ook voor producten van covergisting is er sprake van onduidelijkheid in de $\mathrm{HC}$ van het product. Met name bij co-vergisting van mest kan de stabiliteit van de organischestof en de samenstelling van het digestaat fluctueren tussen verschillende partijen, afhankelijk van de aard en de hoeveelheid van de toegevoegde co-materialen en van de vergistingsduur. De variatie in $\mathrm{HC}$ is daardoor mogelijk groter dan bij niet-vergiste mest.Onder meer in het KB-project Mest, deelproject Evaluatiekader (KB-34-001-003), wordt nader onderzoek gedaan naar een methode om, gestandaardiseerd en snel, de humificatie-coëfficiënt van organische meststoffen te kunnen schatten.

\subsection{Samenvatting}

Met het RothC model is de C-opbouw van mest, mono- en co-vergist digestaat van RDM en VDM berekend op basis van een gelijke $\mathrm{N}_{\mathrm{t}}$-aanvoer van de producten. De resultaten laten zien dat de hoogste C-opbouw werd bereikt door mono-vergist RDM, op afstand gevolgd door co-vergist en onbewerkt RDM. Een veel lagere C-opbouw werd berekend voor VDM en afgeleide mono- en covergistte digestaten. De verhouding in berekende C-opbouw van de producten is RDM : mono-vergist RDM : co-vergist RDM : VDM : mono-vergist VDM : co-vergist VDM = $4: 14: 4: 2: 1: 1$.

Op basis van de gekozen uitgangspunten en de beschikbare gegevens kan uit de berekende resultaten worden geconcludeerd dat, op hectareschaal, mono-vergist RDM substantieel meer bijdraagt aan de C-opbouw in de bodem dan de andere mestprodukten. 


\section{Economische analyse van mono- vergisten met toevoeging van extra $\mathrm{C}$}

In het rapport van Evers et al. (2019) is een vergelijking gemaakt waarbij o.a. de effecten van oude mest vergisten en verse mest vergisten op de arbeidsopbrengst in beeld zijn gebracht ten opzichte van geen mest vergisten. In deze studie berekenen we welke invloed het toevoegen van $5 \%$ bermgras en $10 \%$ bermgras bij verse mest vergisten heeft op de arbeidsopbrengst. Dit wordt zowel gedaan voor een melkveebedrijf als een vleesvarkensbedrijf. Centraal staan de vragen:

A. Wat zijn de technische en economische voor- en nadelen van mono-vergisten met meer toegevoegde $\mathrm{C}$ in een vergister en welke aanbevelingen voor vervolg en beleid volgen hieruit?

B. Wat is het effect van mono-vergisten op de hoeveelheid organische stof die overblijft in het digestaat?

In onderstaande berekeningen is uitgegaan van nieuwbouw, waardoor ook besparingen op investeringen mogelijk zijn, zoals een kleinere put onder de stal. Aangenomen is dat er voor bermgras niet betaald hoeft te worden, maar er ook niet betaald wordt voor de afvoer. Er is wel rekening gehouden met extra kosten (loonwerk, aanpassing vergister) om bermgras toe te kunnen voegen. Aangezien bermgras geen schoon product is, moet rekening gehouden worden met 'schoningskosten'. Omdat hier geen inzicht in is, wordt geen indicatie gegeven van deze kosten, waar dus wel rekening mee gehouden dient te worden. 


\subsection{Melkveebedrijf}

De scenario's uit tabel 6 zijn economisch doorgerekend, zie Tabel 10 voor de resultaten.

Tabel 10 Economische resultaten mono-vergisten melkveebedrijf (bedragen in $€$ als verschil ten opzichte van basis zonder vergisten)

\begin{tabular}{|c|c|c|c|c|}
\hline & \multicolumn{4}{|c|}{ Mono-vergisten t.o.v. niet vergisten } \\
\hline & Oude mest & Verse mest & $\begin{array}{r}\text { Verse mest }+5 \% \\
\text { bermgras toevoegen }\end{array}$ & $\begin{array}{r}\text { Verse mest }+10 \% \\
\text { bermgras toevoegen }\end{array}$ \\
\hline Opbrengsten (A) & +30300 & +36500 & +46000 & +56500 \\
\hline - Melk & +0 & +0 & +0 & +0 \\
\hline - Omzet en aanwas & +0 & +0 & +0 & +0 \\
\hline - Overig melkvee & +0 & +0 & +0 & +0 \\
\hline - Opbrengst vergisten & +30300 & +36500 & +46000 & +56500 \\
\hline * waarvan subsidie elektriciteit & +9800 & +11800 & +14900 & +18300 \\
\hline * waarvan subsidie warmte & +9800 & +11800 & +14900 & +18300 \\
\hline Toegerekende kosten (B) & +100 & -2000 & -2000 & -2000 \\
\hline - Voer & +0 & +0 & +0 & +0 \\
\hline - Vee & +0 & +0 & +0 & +0 \\
\hline - Gewas & +100 & -2000 & -2000 & -2000 \\
\hline * waarvan kunstmest & +100 & -2000 & -2000 & -2000 \\
\hline - Loonwerk & +0 & +200 & +4100 & +8300 \\
\hline * waarvan kosten mest uitrijden & +0 & +200 & +200 & +200 \\
\hline * waarvan maaien en inkuilen bermgras & +0 & +0 & +3800 & +8100 \\
\hline - Werktuigen en installaties & +33500 & +33500 & +53000 & +54600 \\
\hline * waarvan vergistingsinstallatie basis & +33500 & +33500 & +35200 & +36900 \\
\hline * waarvan bermgras aanpassing vergister & +0 & +0 & +16800 & +16800 \\
\hline * waarvan voorlader & +0 & +0 & +1000 & +1000 \\
\hline - Grond en gebouwen & -7800 & -10000 & -8400 & -14200 \\
\hline * waarvan externe mestopslag & +2500 & +5000 & +5600 & +6400 \\
\hline * waarvan kosten stal & -14100 & -18800 & -18800 & -18800 \\
\hline * waarvan opslag bermgras & +0 & +0 & +1000 & +2000 \\
\hline - Water & +0 & +0 & +0 & +0 \\
\hline - Energie & +0 & +0 & +0 & +0 \\
\hline - Mestafvoer & +100 & -1100 & +1400 & +4200 \\
\hline - Algemeen & +0 & +0 & +0 & +0 \\
\hline Arbeidsopbrengst (A - B - C) & +4300 & +16100 & -2000 & -2100 \\
\hline AO zonder subsidie warmte & -5500 & +4200 & -16900 & -20400 \\
\hline
\end{tabular}

Tabel 10 laat zien dat oude mest vergisten een $€ 8.200$ hogere arbeidsopbrengst oplevert wanneer het bedrijf zowel subsidie krijgt voor de geleverde stroom als voor de geproduceerde warmte. Wanneer de warmte niet wordt gesubsidieerd, dan is de arbeidsopbrengst $€ 1.600$ lager ten opzichte van de basissituatie zonder vergisten. In deze studie wordt de benutting van warmte niet meegenomen en kan de warmtesubsidie dus achterwege gelaten worden. De volgende zaken vallen op bij deze variant:

- De vergoeding van de opgewekte stroom en warmte met de vergistingsinstallatie is ingeschat op totaal $€ 30.300$ bij deze variant. Hiervan is ongeveer $€ 19.600$ subsidie. - De opbrengst is in de tabel apart weergegeven, in de praktijk zal een deel van de stroom op het bedrijf zelf worden gebruikt en zullen de energiekosten lager zijn bij vergisten. In de basissituatie verbruikt het bedrijf $78.500 \mathrm{kWh}$ aan stroom en betaalt hiervoor jaarlijks bijna $€ 12.400$, inclusief vastrecht -

- Omdat bij oude mest vergisten ongeveer $100 \mathrm{~kg}$ (a $€ 1$ per kilo) meer N-kunstmest nodig is, zijn de kunstmestkosten iets hoger. 
- De jaarkosten van de vergistingsinstallatie met een inhoud van 465 ton zijn op $€ 33.500$ ingeschat. Het investeringsbedrag is ingeschat op $€ 200.000$. Uitgangspunt is dat de installatie wordt afgeschreven in 10 jaar en dat de jaarlijkse onderhoudskosten $5 \%$ bedragen. De rente over die periode is op $3,5 \%$ ingeschat (KWIN).

- Omdat 690 ton minder mestopslag onder de stal nodig is (690 ton meer opslag buiten de stal) zijn de kosten voor grond en gebouwen $€ 7.000$ lager. Uitgangspunt hierbij is dat externe mestopslag bij deze variant $€ 60$ /ton aan investering kost. In de basis is voor de externe mestopslag een investering van $€ 81$ /ton gerekend (duurder bij kleinere omvang). Voor de mestopslag onder de stal is een investeringsbedrag van $€ 140$ /ton ingerekend (inschatting op basis van KWIN-V 20182019). Uitgangspunt bij bouwwerken zoals mestopslag onder de stal is dat deze in 20 jaar wordt afgeschreven, de externe mestopslag wordt in 15 jaar afgeschreven. Onderhoud is in beide gevallen ongeveer $2 \%$.

- $\quad$ De kosten voor mestafvoer wijken in deze variant nauwelijks af van de basissituatie.

Mono-vergisting toepassen met verse mest leidt tot een $€ 19.900$ hogere arbeidsopbrengst wanneer het bedrijf zowel subsidie krijgt voor de geleverde stroom als voor de geproduceerde warmte. Wanneer de warmte niet wordt gesubsidieerd, dan is de arbeidsopbrengst $€ 8.000$ hoger ten opzichte van de situatie zonder vergisten. De volgende zaken vallen op bij deze variant:

- De vergoeding van de opgewekte stroom en warmte met de vergistingsinstallatie is ingeschat op totaal $€ 36.500$ bij deze variant. Hiervan is $€ 23.600$ subsidie.

- Omdat de stikstofverliezen in deze variant lager zijn dan in de basis, zijn de kunstmestkosten $€$ 2000 lager dan in de basissituatie.

- Omdat er in deze variant minder mestafvoer is, blijft er meer mest op het bedrijf en zijn de loonwerkkosten voor mest toedienen $€ 200$ hoger.

- Net als bij oude mest vergisten zijn de kosten van de vergistingsinstallatie ingeschat op $€ 33.500$ op jaarbasis bij een inhoud van de vergistertank van 465 ton. Dit is bij een afschrijvingstermijn van 10 jaar.

- Doordat nauwelijks mestopslag onder de stal nodig is, is de externe opslagcapaciteit bijna 1300 groter,. De gebouwenkosten zijn $€ 10.000$ lager door de kleinere opslag onder de stal en goedkopere externe opslag (investering van deze grote opslag is $€ 55 /$ ton). De kosten van de vloer zijn bij toepassen van een dichte vloer met mestschuif (RAV A 1.8) wel $€ 15$ per koeplaats hoger.

- Omdat de afgevoerde digestaat een hoger stikstofgehalte heeft dan de afgevoerde mest in de basissituatie zijn de kosten voor mestafvoer $€ 1100$ lager.

Mono-vergisting toepassen met verse mest en toevoegen van $5 \%$ bermgras (ongeveer 70 ton ds) leidt tot een $€ 1.800$ hogere arbeidsopbrengst wanneer het bedrijf zowel subsidie krijgt voor de geleverde stroom als voor de geproduceerde warmte. Wanneer de warmte niet wordt gesubsidieerd, dan is de arbeidsopbrengst $€ 13.100$ lager ten opzichte van de situatie zonder vergisten. De volgende zaken vallen op bij deze variant wanneer we kijken naar de verschillen met alleen verse mest vergisten zonder toevoeging:

- Door ongeveer $18.000 \mathrm{~m}^{3}$ meer biogas produceren neemt de opbrengst van vergisten met ongeveer $€ 9.500$ toe ten opzichte van verse mest vergisten.

- Het maaien, hakselen en inkuilen van bermgras door de loonwerker leidt tot ongeveer $€ 3.800$ meer loonwerkkosten voor het bermgras wat gebruikt wordt om toe te voegen aan de vergister.

- Bij toevoegen van $5 \%$ bermgras stijgt de benodigde capaciteit van de vergisten van 465 ton naar ruim 490 ton. Deze uitbreiding leidt tot $€ 1.700$ extra jaarkosten.

- Om mest en bermgras samen te kunnen vergisten is een toevoermechanisme nodig en moeten de leidingen en slangen ruimer gedimensioneerd zijn. De extra investering voor deze aanpassing is ingeschat op $€ 100.000$. Bij 10 jaar afschrijving, 5\% onderhoud en 3,5\% rente stijgen de jaarkosten door deze aanpassing met $€ 16.800$.

- Om het bermgras van de kuil in het toevoermechanisme van de vergister te brengen is een voorlader op de trekker nodig. De extra kosten hiervoor zijn op $€ 1.000$ ingeschat.

- Door toevoeging van bermgras aan de mest is $120 \mathrm{~m}^{3}$ extra externe mestopslag nodig, dit kost $€$ 600 per jaar extra bij een investering van $€ 55 /$ ton opslag.

- Voor opslag van bermgras is een extra kuilplaat nodig en afdekking met 2 lagen landbouwplastic. Jaarkosten hiervoor zijn op $€ 1.000$ ingeschat. 
- Omdat bij toevoegen van bermgras meer mineralen als co-product in de mest terechtkomen is 228 ton extra mestafvoer nodig. De jaarkosten voor mestafvoer stijgen hierdoor met $€ 2.500$ ten opzichte van verse mest vergisten.

Mono-vergisting toepassen met verse mest en toevoegen van $10 \%$ bermgras (ongeveer 149 ton ds) leidt tot een $€ 1.700$ hogere arbeidsopbrengst wanneer het bedrijf zowel subsidie krijgt voor de geleverde stroom als voor de geproduceerde warmte. Wanneer de warmte niet wordt gesubsidieerd, dan is de arbeidsopbrengst $€ 16.600$ lager ten opzichte van de situatie zonder vergisten. De volgende zaken vallen op bij deze variant wanneer we kijken naar de verschillen met alleen verse mest vergisten zonder toevoeging:

- Door ongeveer $38.000 \mathrm{~m}^{3}$ meer biogas produceren neemt de opbrengst van vergisten met ongeveer $€ 20.000$ toe ten opzichte van verse mest vergisten.

- Het maaien, hakselen en inkuilen van bermgras door de loonwerker leidt tot ongeveer $€ 3.800$ meer loonwerkkosten voor het bermgras wat gebruikt wordt om toe te voegen aan de vergister.

- Bij toevoegen van $10 \%$ bermgras stijgt de benodigde capaciteit van de vergisten van 465 ton naar bijna 510 ton. Deze uitbreiding leidt tot $€ 3.400$ extra jaarkosten.

- Om mest en bermgras samen te kunnen vergisten is een toevoermechanisme nodig en moeten de leidingen en slangen ruimer gedimensioneerd zijn. De extra investering voor deze aanpassing is ingeschat op $€ 100.000$. Bij 10 jaar afschrijving, 5\% onderhoud en 3,5\% rente stijgen de jaarkosten door deze aanpassing met $€ 16.800$.

- Om het bermgras van de kuil in het toevoermechanisme van de vergister te brengen is een voorlader op de trekker nodig. De extra kosten hiervoor zijn op $€ 1.000$ ingeschat.

- Door toevoeging van bermgras aan de mest is $250 \mathrm{~m}^{3}$ extra externe mestopslag nodig, dit kost $€$ 1400 per jaar extra bij een investering van $€ 55 /$ ton opslag.

- Voor opslag van bermgras is een extra kuilplaat nodig en afdekking met 2 lagen landbouwplastic. Jaarkosten hiervoor zijn op $€ 2.000$ ingeschat.

- Omdat bij toevoegen van bermgras meer mineralen als co-product in de mest terechtkomen is 487 ton extra mestafvoer nodig. De jaarkosten voor mestafvoer stijgen hierdoor met ruim $€ 5.300$ ten opzichte van verse mest vergisten.

\subsection{Conclusie melkveebedrijf}

Tabel 11 laat zien dat toevoegen van bermgras leidt tot een forse daling van de arbeidsopbrengst ten opzichte van verse mest vergisten. Vooral de extra kosten van het aanpassen van de vergister leiden tot fors hogere kosten. Deze wegen niet op tegen de extra opbrengsten.

Als in plaats van nieuwbouw uitgegaan wordt van bestaande bouw, komen een aantal besparingen te vervallen. Dit betekent een daling van het resultaat met respectievelijk $€ 7.000$ en $€ 10.000$ bij het vergisten van oude en verse mest.

In de berekening van de arbeidsopbrengst zijn de extra kosten van arbeid niet meegenomen. Wanneer bij de opties "oude mest vergisten" en "verse mest vergisten" een half uur extra per dag nodig is, dan daalt het resultaat ten opzichte van niet vergisten met $€ 5.000$. Het resultaat van oude mest vergisten komt dan ongeveer $€ 3.200$ hoger uit dan bij geen mest vergisten en bij verse mest vergisten is het resultaat $€ 14.900$ hoger dan bij geen mest vergisten. Bij de opties met bermgras toevoegen is meer arbeid nodig. Bij een uur per dag extra ten opzichte van niet vergisten daalt het resultaat met ongeveer $€ 10.000$ en leidt verse mest vergisten met $5 \%$ of $10 \%$ bermgras toevoegen tot een daling van de arbeidsopbrengst van ruim $€ 8.000$ ten opzichte van geen mest vergisten. 


\subsection{Vleesvarkensbedrijf}

In Tabel 11 staan de resultaten van de berekening met vleesvarkensmest waarbij gebruik is gemaakt van de uitgangspunten uit Evers at al. (2019). De resultaten van oude mest vergisten en verse mest vergisten zijn ten opzichte van dit rapport wel wat aangepast aan de nieuwste inzichten (iets hogere gasopbrengst en meest recente SDE-subsidiebedragen).

Tabel 11 Economische resultaten mono-vergisten vleesvarkensbedrijf

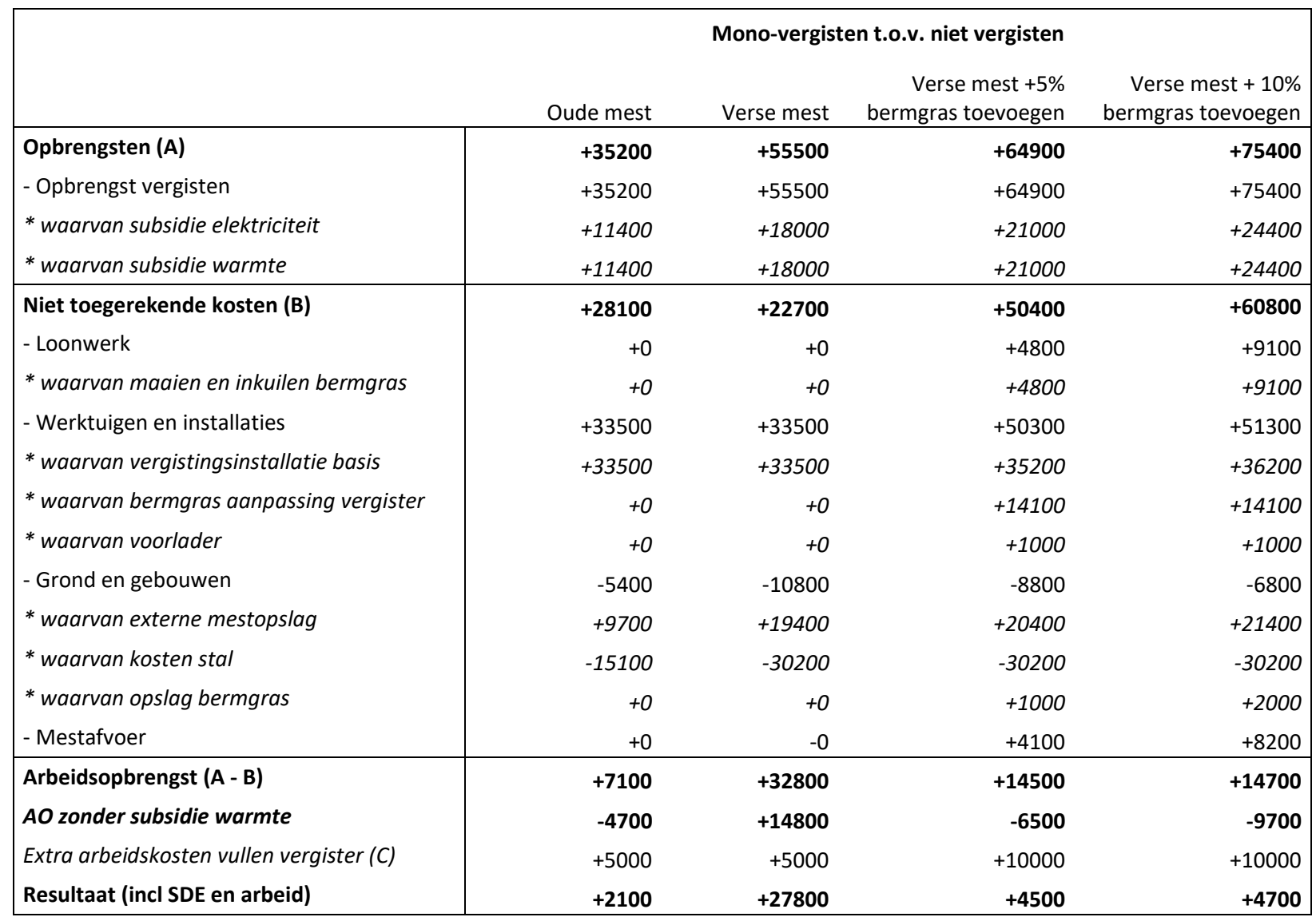

Tabel 11 laat zien dat oude mest vergisten een arbeidsopbrengst van $€ 7.100$ oplevert wanneer het bedrijf zowel subsidie krijgt voor de geleverde stroom als voor de geproduceerde warmte. Wanneer de warmte niet wordt gesubsidieerd (wat in deze studie het geval is omdat de warmte niet mee wordt genomen), dan isde arbeidsopbrengst $€ 4.700$ lager ten opzichte van de basissituatie zonder vergisten. De volgende zaken vallen op bij deze variant:

- De vergoeding van de opgewekte stroom en warmte met de vergistingsinstallatie is ingeschat op totaal $€ 35.200$ bij deze variant. Hiervan is ongeveer $€ 22.800$ subsidie. - De opbrengst is in de tabel apart weergegeven, in de praktijk zal een deel van de stroom op het bedrijf zelf worden gebruikt en zullen de energiekosten lager zijn bij vergisten.

- De jaarkosten van de vergistingsinstallatie met een inhoud van 465 ton zijn op $€ 33.500$ ingeschat. Het investeringsbedrag is ingeschat op $€ 200.000$. Uitgangspunt is dat de installatie wordt afgeschreven in 10 jaar en dat de jaarlijkse onderhoudskosten $5 \%$ bedragen. De rente over die periode is op 3,5\% ingeschat (KWIN-V).

- Omdat er zo'n 1100 ton minder mestopslag onder de stal nodig is, zijn de kosten voor grond en gebouwen $€ 5.400$ lager. Uitgangspunt hierbij is dat externe mestopslag $€ 60$ /ton aan investering kost en mestopslag onder de stal $€ 140$ /ton aan investering kost (inschatting op basis van KWINV 2018-2019). Uitgangspunt bij bouwwerken zoals mestopslag onder de stal is dat deze in 20 jaar wordt afgeschreven, de externe mestopslag wordt in ongeveer 15 jaar afgeschreven. Onderhoud is in beide gevallen ongeveer $2 \%$.

- De kosten voor mestafvoer wijken in deze variant nauwelijks af van de basissituatie. 
Mono-vergisting toepassen met verse mest leidt tot een toename in arbeidsopbrengst van $€ 32.800$ wanneer het bedrijf zowel subsidie krijgt voor de geleverde stroom als voor de geproduceerde warmte. Wanneer de warmte niet wordt gesubsidieerd, dan is de arbeidsopbrengst $€ 14.800$ ten opzichte van de situatie zonder vergisten. De volgende zaken vallen op bij deze variant:

- De vergoeding van de opgewekte stroom en warmte met de vergistingsinstallatie is ingeschat op totaal $€ 55.500$ bij deze variant. Hiervan is $€ 36.000$ subsidie.

- Net als bij oude mest vergisten zijn de kosten van de vergistingsinstallatie ingeschat op $€ 33.500$ op jaarbasis bij een inhoud van de vergistertank van 465 ton. Dit is bij een afschrijvingstermijn van 10 jaar.

- Doordat nauwelijks mestopslag onder de stal nodig is, is de externe opslagcapaciteit bijna 1300 groter, naast de 465 ton opslag van de vergistertank. De gebouwenkosten zijn $€ 10.800$ lager door de kleinere opslag onder de stal en goedkopere externe opslag.

Mono-vergisting toepassen met verse mest en toevoegen van 5\% bermgras (ongeveer 70 ton ds) leidt tot een hogere arbeidsopbrengst van $€ 14.500$ wanneer het bedrijf zowel subsidie krijgt voor de geleverde stroom als voor de geproduceerde warmte. Wanneer de warmte niet wordt gesubsidieerd, dan is de arbeidsopbrengst $€-6.500$ ten opzichte van de situatie zonder vergisten. De volgende zaken vallen op bij deze variant wanneer we kijken naar de verschillen met alleen verse mest vergisten zonder toevoeging:

- Door ongeveer $18.500 \mathrm{~m}^{3}$ meer biogas produceren neemt de opbrengst van vergisten met ongeveer $€ 9.400$ toe ten opzichte van verse mest vergisten.

- Het maaien, hakselen en inkuilen van bermgras door de loonwerker leidt tot ongeveer $€ 4.800$ meer loonwerkkosten voor het bermgras wat gebruikt wordt om toe te voegen aan de vergister.

- Bij toevoegen van $5 \%$ bermgras stijgt de benodigde capaciteit van de vergisten van 465 ton naar ruim 490 ton. Deze uitbreiding leidt tot $€ 1.700$ extra jaarkosten.

- Om mest en bermgras samen te kunnen vergisten is een toevoermechanisme nodig en moeten de leidingen en slangen ruimer gedimensioneerd zijn. De extra investering voor deze aanpassing is ingeschat op $€ 100.000$. Bij 10 jaar afschrijving, 5\% onderhoud en 3,5\% rente stijgen de jaarkosten door deze aanpassing met $€ 16.800$.

- Om het bermgras van de kuil in het toevoermechanisme van de vergister te brengen is een voorlader op de trekker nodig. De extra kosten hiervoor zijn op $€ 1.000$ ingeschat.

- Door toevoeging van bermgras aan de mest is $120 \mathrm{~m}^{3}$ extra externe mestopslag nodig, dit kost $€$ 1000 per jaar extra.

- Voor opslag van bermgras is een extra kuilplaat nodig en afdekking met 2 lagen landbouwplastic. Jaarkosten hiervoor zijn op $€ 1.000$ ingeschat.

- Omdat bij toevoegen van bermgras meer mineralen als co-product in de mest terechtkomen is extra mestafvoer nodig. De jaarkosten voor mestafvoer stijgen hierdoor met $€ 4.100$ ten opzichte van verse mest vergisten.

Mono-vergisting toepassen met verse mest en toevoegen van $10 \%$ bermgras (ongeveer 149 ton ds) leidt tot een hogere arbeidsopbrengst van $€ 14.700$ wanneer het bedrijf zowel subsidie krijgt voor de geleverde stroom als voor de geproduceerde warmte. Wanneer de warmte niet wordt gesubsidieerd, dan is de arbeidsopbrengst $€-9.700$ ten opzichte van de situatie zonder vergisten. De volgende zaken vallen op bij deze variant wanneer we kijken naar de verschillen met alleen verse mest vergisten zonder toevoeging:

- Door ongeveer $39.000 \mathrm{~m}^{3}$ meer biogas produceren neemt de opbrengst van vergisten met ongeveer $€ 20.000$ toe ten opzichte van verse mest vergisten.

- Het maaien, hakselen en inkuilen van bermgras door de loonwerker leidt tot ongeveer $€ 9.100$ meer loonwerkkosten voor het bermgras wat gebruikt wordt om toe te voegen aan de vergister.

- Bij toevoegen van $10 \%$ bermgras stijgt de benodigde capaciteit van de vergisten van 465 ton naar bijna 510 ton. Deze uitbreiding leidt tot $€ 3.700$ extra jaarkosten.

- Om mest en bermgras samen te kunnen vergisten is een toevoermechanisme nodig en moeten de leidingen en slangen ruimer gedimensioneerd zijn. De extra investering voor deze aanpassing is ingeschat op $€ 100.000$. Bij 10 jaar afschrijving, 5\% onderhoud en 3,5\% rente stijgen de jaarkosten door deze aanpassing met $€ 17.800$.

- Om het bermgras van de kuil in het toevoermechanisme van de vergister te brengen is een voorlader op de trekker nodig. De extra kosten hiervoor zijn op $€ 1.000$ ingeschat. 
- Door toevoeging van bermgras aan de mest is $250 \mathrm{~m}^{3}$ extra externe mestopslag nodig, dit kost ruim $€ 2.000$ per jaar extra.

- Voor opslag van bermgras is een extra kuilplaat nodig en afdekking met 2 lagen landbouwplastic. Jaarkosten hiervoor zijn op $€ 2.000$ ingeschat.

- Omdat bij toevoegen van bermgras meer mineralen als co-product in de mest terechtkomen is extra mestafvoer nodig. De jaarkosten voor mestafvoer stijgen hierdoor met $€ 8.200$ ten opzichte van verse mest vergisten.

\subsection{Conclusie vleesvarkensbedrijf}

Tabel 11 laat zien dat toevoegen van bermgras leidt tot een forse daling van de arbeidsopbrengst ten opzichte van verse mest vergisten. Vooral de extra kosten van het aanpassen van de vergister voor verwerken van bermgras leiden tot fors hogere kosten. Deze wegen niet op tegen de extra opbrengsten.

Als in plaats van nieuwbouw uitgegaan wordt van bestaande bouw, komen een aantal besparingen te vervallen. Dit betekent een daling van het resultaat met respectievelijk $€ 5.400$ en $€ 10.800$ bij het vergisten van oude en verse mest.

In de berekening van de arbeidsopbrengst zijn de extra kosten van arbeid niet meegenomen. Wanneer bij de opties "oude mest vergisten" en "verse mest vergisten" een half uur extra per dag nodig is, dan daalt het resultaat ten opzichte van niet vergisten met $€ 5.000$. Het resultaat van oude mest vergisten komt dan ongeveer op $€ 2.100$ uit en van verse mest vergisten ongeveer $€ 27.800$ hoger dan bij geen mest vergisten. Bij de opties met bermgras toevoegen is meer arbeid nodig. Bij een uur per dag daalt het resultaat met ongeveer $€ 10.000$ en leidt verse mest vergisten tot een daling van de arbeidsopbrengst van ongeveer $€ 4.500$ ten opzichte van geen mest vergisten. 


\title{
6 Beantwoording kennisvragen
}

\author{
1. In hoeverre draagt mono-vergisten bij aan de klimaatdoelstellingen en reductie \\ van emissies vanaf de bodem?
}

Alle onderzochte vergistingsscenario's leveren een reductie van emissie van broeikasgassen op omdat er 'groene elektriciteit' opgewekt wordt. Op basis van de uitgangspunten laat het vergistingsmodel zien dat met het vergisten van oude RDM $122 \mathrm{CO}_{2}$ equivalent per jaar vermeden wordt, meteen naar de vergister getransporteerde RDM vermijdt $147 \mathrm{CO}_{2}$ equivalent per jaar. Het produceren van biogas zorgt bij vergisting van oude RDM voor een netto winst, wanneer de vermeden broeikasgassen buiten beschouwing wordt gelaten levert het vergisten van oude RDM een kleine toename (5\%) aan broeikasgas emissie op.

Dezelfde trent is te zien bij VDM, met het vergisten van oude VDM wordt $142 \mathrm{CO}_{2}$ equivalent per jaar vermeden, meteen naar de vergister getransporteerde VDM vermijdt $223 \mathrm{CO}_{2}$ equivalent per jaar. Wanneer de vermeden broeikasgassen bij VDM buiten beschouwing wordt gelaten levert het vergisten van oude VDM een kleine toename ( $8 \%$ ) aan broeikasgas emissie op.

Uit de modelberekeningen komt naar voren dat de $\mathrm{NH}_{3}$-emissie van digestaat van oude mest ongeveer $10-20 \%$ hoger is dan van onbewerkte mest. Echter, bij onbewerkte mest ten opzichte van meteen naar de vergister getransporteerde mest, neemt de $\mathrm{NH}_{3}$ emissie juist met een 20 tot $30 \%$ af (voor respectievelijk RDM en VDM).

De emissie van $\mathrm{NH}_{3}$ uit de vergister wordt verwaarloosbaar geacht ten opzichte van de emissie die optreedt tijdens opslag van drijfmest in de stal en opslag van het digestaat. Vanuit de stal treedt er minder emissie op, juist omdat mest vanuit de stal rechtstreeks naar de vergister gaat.

De literatuur is niet altijd eenduidig met betrekking tot de emissies van $\mathrm{NH}_{3}$ uit digestaat:

aanwending, (weers)omstandigheden en toedieningstechnieken spelen hierin een groter rol. Wanneer viscositeit buiten beschouwing wordt gelaten, wordt aangenomen dat de $\mathrm{NH}_{3}$ emissie bij aanwending van digestaat hoger is dan van onvergiste mest vanwege het hogere aandeel $\mathrm{NH}_{4}-\mathrm{N}$ in de mest.

In de modelberekeningen wordt aangenomen dat het $\mathrm{CH}_{4}$ verlies uit de vergister gemiddeld $4 \%$ bedraagt. Er wordt aangenomen dat de aanwending geen invloed heeft op de productie van methaan. $\mathrm{Er}$ zit weinig verschil in $\mathrm{N}_{2} \mathrm{O}$ emissie volgens de modelberekeningen waarbij veengrond (met een hogere $\mathrm{N}_{2} \mathrm{O}$ emissie) niet is meegenomen. De literatuur laat zowel gevallen zien waarbij de $\mathrm{N}_{2} \mathrm{O}$ toeneemt als waarbij de emissie van $\mathrm{N}_{2} \mathrm{O}$ afneemt bij aanwending van digestaat in vergelijking met onvergiste mest. De samenstelling van het digestaat in combinatie met bodemcondities en klimatologische omstandigheden bepaalt of er bij aanwending sprake is van een afname of toename.

\section{Draagt een hogere $\mathrm{C} / \mathrm{N}_{\text {org }}$ verhouding in de mest bij aan een verbetering van de effecten op van de klimaatdoelstellingen en emissiereducties?}

Uit de modelberekeningen blijkt dat bij het toevoegen van co-vergistingsmaterialen de emissie van $\mathrm{NH}_{3}$ met $2 \%$ toeneemt wanneer er $5 \%$ covergistingsmateriaal aan de RDM en VDM wordt toegevoegd, en er is een toename $4 \%$ wanneer er $10 \%$ co-vergistingsmateriaal aan RDM en VDM wordt toegevoegd. Ook de emissie van $\mathrm{CH}_{4}$ neemt met $5 \%$ en $14 \%$ toe voor respectievelijk $5 \%$ en $10 \%$ covergist RDM en VDM. Het toevoegen van co-vergistingsmaterialen heeft praktisch geen invloed op de $\mathrm{N}_{2} \mathrm{O}$ emissie. Er wordt echter meer biogas geproduceerd wanneer er co-vergistingsmaterialen worden toegevoegd, het heeft daarmee netto een positief effect op de reductie van (broeikasgas) emissies. Het vergisten van RDM met co-substraat vermijdt meer emissie dan mono-vergisten. In vergelijking met onvergiste RDM wordt er 185 en $228 \mathrm{CO}_{2}$ equivalent per jaar voor respectievelijk $5 \%$ en $10 \%$ co-substraat aan broeikasgasemissies vermeden. Ook het vergisten van VDM met cosubstraat schroeft de emissie ten opzichte van onvergiste VDM op met 261 en $304 \mathrm{CO}_{2}$ equivalent per jaar voor respectievelijk $5 \%$ en $10 \%$ co-substraat. Een hogere $\mathrm{C} / \mathrm{N}_{\text {org }}$ verhouding draagt dus bij aan de verbetering van de effecten op klimaatdoelstellingen en emissiereducties. 


\section{Wat is het effect van digestaat op de bodemkwaliteit?}

Uit de literatuur en Nederlands veldonderzoek komt naar voren dat de bemestende waarde van digestaat vooral op korte termijn kan verschillen met die van onbewerkte mest, de eerstejaars $\mathrm{N}$ werking van digestaat lijkt hoger. Wisselende samenstellingen van de gebruikte mestproducten zorgen ervoor dat de literatuur niet eenduidig is over verschillen in de mineralisatie van mestproducten. Ook uit de beperkte hoeveelheid literatuur over effecten van digestaat en onbewerkte mest op bodemleven komt een wisselend beeld naar voren. Organische stof kan op verschillende manieren bijdragen aan de bodemkwaliteit en gewasproduktie. Verschillen tussen digestaat en niet-vergistte mest zijn moeilijk te kwantificeren en vereist langjarig systeemonderzoek.

\section{Wat zijn de kwantitatieve effecten van digestaat op de organische stof opbouw van de bodem in vergelijking met onbewerkte mest?}

Uit de modelberekeningen blijkt dat het verschil in OS-opbouw tussen onbewerkt RDM en co-vergist RDM digestaat gering is. Met mono-vergist RDM is zelfs een forse stijging van het OS-gehalte in de bodem te realiseren, wanneer de aanvoer van N-totaal als uitgangspunt wordt genomen. Voor VDM geldt echter dat de digestaten (mono en co-vergist) tot een lagere OS-opbouw leiden dan de onbewerkte mest. De vraag, of het gebruik van digestaat leidt tot een verminderde opbouw van organische stof in de bodem is dan ook niet met een eenvoudig ja of nee te beantwoorden. Een eerste onderscheid is te maken tussen RDM en VDM, maar het effect hangt uiteindelijk af van de samenstelling van het uitgangsmateriaal (-materialen) waaruit het digestaat is gemaakt. In de huidige modellen zijn het OS-gehalte en de humificatie-coëfficiënt de belangrijkste parameters van de producten. De $\mathrm{C} / \mathrm{N}$-ratio speelt ook een rol, maar de relatie met de humificatie-coëfficiënt dient nader te worden onderzocht. Opgemerkt zij dat een eventueel lagere OS-opbouw door digestaat niet per sé leidt tot een lagere bodemkwaliteit. Dit hangt enerzijds af van de benodigde aanvoer op de organische stofbalans, anderzijds van de kwaliteit van de reeds aanwezige organische stof in de bodem, als ook van overige aspecten van bodemkwaliteit.

\section{Wat zijn de technische en economische voor- en nadelen van een hogere $\mathbf{C}$ vracht in de vergister?}

Het toevoegen van bermgras leidt tot een forse daling van de arbeidsopbrengsten ten opzichte van verse mest vergisten. Dit komt voornamelijk door de extra kosten die het aanpassen van de vergister met zich meebrengt. Het vergisten van oude mest levert bij VDM economische winst op ten opzichte van onvergiste mest; bij RDM levert het verlies op. Bij beide mestsoorten levert het vergisten van verse mest de meeste winst op. De technische voor- en nadelen van bermgras vergisten zijn niet onderzocht in dit onderzoek, maar RVO (2015) geeft wel degelijk een aantal aandachtspunten: het voorkomen van zand/grond, het voldoende voorbewerken van de input, de aanwezigheid van plastic en metaal in de bermen en de kans op sterke waardevermindering van het materiaal bij langduroge opslag. 


\section{Conclusies en aanbevelingen}

\section{Conclusies}

Opslag van mest, toedieningstechniek, (weers)omstandigheden, viscositeit van de mest en bodemcondities hebben een grote invloed op de emissie die vervolgens vrijkomt. De literatuur is niet eenduidig over de emissies die optreden wanneer onbewerkte mest of digestaat wordt toegediend aan de bodem. Er is nog weinig (veld) onderzoek gedaan naar het verschil in bemestende waarde, bodemleven en organische stof afbraak van digestaat van RDM en VDM.

Op basis van de gekozen uitgangspunten en aannames kan worden geconcludeerd dat het wel of niet meteen transporteren van mest naar de vergister het meest bepalend is of digestaat bijdraagt aan de reductie van emissies of niet. Vanwege de extra productie van biogas heeft het toevoegen van covergistingsmaterialen netto een positief effect op de reductie van (broeikasgas)emissies.

Op basis van de gekozen uitgangspunten en de beschikbare gegevens voor het ROTHC-model kan uit de berekende resultaten worden geconcludeerd dat mono-vergist RDM substantieel meer bijdraagt aan de C-opbouw in de bodem dan de andere mestprodukten in deze scenario-analyse.

Het toevoegen van bermgras in de vergister levert geen economisch voordeel op.

\section{Kennislacunes, aanbevelingen voor vervolg onderzoek en beleid}

Uit het literatuuronderzoek en de modelberekeningen komen de volgende punten naar voren voor nader onderzoek:

- De berekende meerwaarde van mono-vergist RDM voor de organische stofopbouw is vastgesteld met een conservatieve inschatting van de benodigde parameters. Niettemin is de uitkomst opvallend. Aanbevolen wordt om de scenario-analyse uit te breiden met een foutenanalyse en/of de uitkomsten te valideren in de praktijk;

- Experimenteel werk aan de humificatie-coëfficiënt en mineralisatie parameters van organische meststoffen is nodig, zowel wat betreft de productkarakteristieken (R\&D) als de effecten op de bodem bij landbouwkundige gebruik (langlopende veldproeven);

- Het is nog onduidelijk welke processen in de bodem het verschil tussen berekende en gemeten $\mathrm{N}$-werking tussen digestaat en mest kunnen verklaren. Het is daarom aan te bevelen om veld- en labmetingen uit te voeren waarin RDM en VDM met het bijbehorende digestaat toegediend worden aan de bodem en de resultaten van de metingen te vergelijken met modelberekeningen;

- Meta-analyse van beschikbare onderzoeken naar het relatieve belang van de factoren die bijdragen aan de emissieprocessen van mest en digestaat na toediening;

- Meten van de ammoniakemissie bij toepassing van digestaat t.o.v. onvergiste mest bij verschillende oppervlakkige of ondiepe toedieningsmethoden;

Verschil tussen (permanent) grasland en bouwland voor opbouw van organische stof;

- Verschil tussen de grondsoorten en tussen percelen met hoog en laag OS-gehalte bij de opbouw van organische stof;

- Korte en lange termijn effecten van digestaat op fysische bodemeigenschappen zoals watervasthoudend vermogen en indringingsweerstand;

- Effecten van de $\mathrm{C} / \mathrm{N}_{\text {org }}$ ratio van organische meststoffen op de C- en $\mathrm{N}$-mineralisatie, en

- Effecten van de toepassing van digestaat op bacteriën en schimmels en humane/dierlijk ziektekiemen;

- Technische en economische analyse van de verschillende scenario's met andere C-producten. 
De wisselende samenstelling van digestaat en overige dierlijke mestprodukten is van groot effect op de emissies van broeikasgassen tijdens de vergisting en de organische stofopbouw in de bodem na toediening. Aanbeveling voor het beleid is om, waar mogelijk, rekening te houden met deze bandbreedte in de samenstellingen. 


\section{Literatuur}

Abubaker, J., M. Odlare \& M. Pell (2013). Nitrous oxide production from soils amended with biogas residues and cattle slurry. Journal of Environmental Quality: 42 (4) 1046-1058

Adamu, G. K. \& A K Aliyu (2012). Determination of the Influence of Texture and Organic Matter on Soil Water Holding Capacity in and Around Tomas Irrigation Scheme. Dambatta Local Government Kano State Research Journal of Environmental and Earth Sciences: 4 (12) 1038-1044

Aguirre-Villegas, H.A., R.A. Larson \& D.J. Reinemann (2014). From waste-to-worth: energy, emissions, and nutrient implications of manure processing pathways. Biofuels, Bioprod. Bioref. 8:770793. DOI: $10.1002 / \mathrm{bbb} .1496$

Alburquerque, J.A., Fuente, C.D., Campoy, M., Carrasco, L., Nájera, I., Baixauli, C., Caravaca, F., Roldán, A.J., Cegarra, J., \& Bernal, M.P. (2012). Agricultural use of digestate for horticultural crop production and improvement of soil properties. European Journal of Agriculture: 43 119-128

Amon, B., V. Kryvoruchko, T. Amon \& S. Zechmeister-Boltenstern (2006). Methane, nitrous oxide and ammonia emissions during storage and after application of dairy cattle slurry and influence of slurry treatment. Agriculture Ecosystems \& Environment 112 (2-3), 153-162.

Auweele, van den, W. (2012). Kwaliteitscontrole bij de productie van organische meststoffen/ bodemverbeterende middelen (digestaat, compost) en hun karakterisatie. Vlaco vzw voor VCM studiedag 31 jan.2012.

Beni, C., P. Servadio, S. Marconi, U. Neri, R. Aromolo \& G. Diana (2012). Anaerobic Digestate Administration: Effect on Soil Physical and Mechanical Behavior. Communications in Soil Science and Plant Analysis: 43 (5) 821-834. DOI: 10.1080/00103624.2012.648359

Bermejo Domínguez, G. (2012). Agro-ecological aspects when applying the remaining products from agricultural biogas processes as fertilizer in crop production.

Boer, H.C de (2004). Stikstoflevering uit onvergiste en vergiste runderdrijfmest nazodebemesting van grasland op zware zeeklei. Animal Sciences Group / Praktijkonderzoek, Lelystad, Praktijkrapport Rundvee $51,40 \mathrm{p}$

Boer, H.C de \& M. Timmerman (2006). Stikstofopname door gras uit vijf co-vergiste varkensdrijfmesten in een geconditioneerde potproef. Rapport 19, Animal Sciences Group, Wageningen UR, $14 \mathrm{p}$.

Bruggen, van, C., A. Bannink, C.M. Groenestein, J.F.M. Huijsmans, H.H. Luesink, S.M. van der Sluis, G.L. Velthof \& J. Vonk (2018). Emissies naar lucht uit de landbouw in 2016. Berekeningen met het model NEMA. WOt-technical report 119. Wageningen UR. https://doi.org/10.18174/452369

Büeler, E. (2011). CH4-Emissionen bei EPDM-Gasspeichern und deren wirtschaftlichen und ökologischen Folgen. Report for Swiss Bundesamt für Energie (BFE), Switzerland.

Burgt, G.J.H.M. van der, P.H.M. Dekker, W.C.A. van Geel, J.G. Bokhorst \& W. van den Berg (2011). Duurzaamheid organische stof in mest. Analysemethoden om de stabiliteit van de organische stof van verschillende organische meststoffen inclusief digestaat te beoordelen. Eindrapportage 2010. Biokennis. PPO nr. 448. PPO-AGV, Lelystad, 72 p

Chantigny, M. H., D. A. Angers, P. Rochette, G. Bélanger, D. Massé, \& D. Côté (2007). Gaseous Nitrogen Emissions and Forage Nitrogen Uptake on Soils Fertilized with Raw and Treated Swine Manure. J. Environ. Qual. 36:1864-1872. doi:10.2134/jeq2007.0083 
CDM (Commissie Deskundigen Meststoffenwet) (2013). Protocol beoordeling stoffen Meststoffenwet. Versie 3.1. Wageningen, Wettelijke Onderzoekstaken Natuur \& Milieu, WOt-werkdocument 335.72 blz. 4. fig.; 2 tab.; 34. ref.; 7 bijl.

Coenen, P.W.H.G., M.C. van Zanten, P.J. Zijlema, E.J.M.M. Arets, K. Baas, A.C.W.M. van den Berghe, E.P. van Huis, G. Geilenkirchen, M. 't Hoen, M. Hoogsteen, R. te Molder, R. Dröge, J.A. Montfoort, C.J. Peek, J. Vonk, S. Dellaert \& W.W.R. Koch (2018). Greenhouse Gas Emissions in the Netherlands, 1990-2016, National Inventory Report 2018, RIVM Report 2018-0006. DOI 10.21945/RIVM-20180006

Coleman, K \& D.S. Jenkinson (2014). RothC - A model for the turnover of carbon in soil. Rothamsted Research

Crolla, A., C. Kinsley \& E. Pattey (2013). Land application of digestate. The Biogas handbook: $302-325$ DOI: $10.1533 / 9780857097415.2 .302$

Cuijpers W. \& L. Janmaat (2015). Digestaat. Benutting Organische Kingloopstikstof, 2015-029 LbP , $20 \mathrm{p}$.

Cuijpers, W., \& M. van de Water (2014). Toepassing gefilterd digestaat in de biologische fruitteelt, Resultaten demo 2014

Daniel-Gromke, J., J. Liebetrau, V. Denysenko \& C. Krebs (2015). Digestion of bio-waste - GHG emissions and mitigation potential. Energy, Sustainability and Society 5, 1-12.

Dekker, P.H.M., J.G.M. Paauw \& W. van den Berg (2008). Biogas Flevoland. Verslag van het veldonderzoek in 2007 naar de landbouwkundige waarde van co-vergiste mest. PPO-AGV, projectnr. $3251046400,97 \mathrm{p}$.

Dijk W. van, J.J. Schröder, L.B.J Šebek, J. Oemema, J.G. Conijn, Th.V. Vellinga, J. de Boer, M.H.A. de Haan \& J. Verloop (2020) Rekenregels van de kringloopwijzer 2019; achtergronden van BEX, BEA, BEN, BEP en BEC: actualisatie van se 2018-versie. Wageningen Research, rapport WPR-956.

Ehlert, P.A.I., J. Nelemans \& G.L. Velthof (2012). Stikstofwerking van mineralenconcentraten. Stikstofwerkingscoëfficiënten en verliezen door denitrificatie en stikstofimmobilisatie bepaald onder gecontroleerde omstandigheden. Alterra-rapport 2314, ISSN 1566-7197; https://edepot.wur.nl/235503

Evers, A. (2013a). Factsheet Broeikasgassen:methaan, http://edepot.wur.nl/247496

Evers, A. (2013b). Factsheet Broeikasgassen:lachgas, http://edepot.wur.nl/247494

Evers, A., F. de Buisonjé, R. Melse, N. Verdoes \& M. de Haan (2019). Scenariostudie mono-vergisten op melkveebedrijf met veengrond. Wageningen Livestock Research, rapport 1175.

http://edepot.wur.nl/494569

Ernst, G., A. Müller, H. Göhler \& C. Emmerling (2008). C and N turnover of fermented residues from biogas plants in soil in the presence of three different earthworm species (Lumbricus terrestris, Aporrectodea longa, Aporrectodea caliginosa). Soil Biology and Biochemistry: 40, 1413-1420.

Fangueiro, D., M. Senbayran, H. Trindade \& D. Chadwick (2008). Cattle slurry treatment by screw press separation and chemically enhanced settling: effect on greenhouse gas emissions alter land spreading and grass yield. Bioresource Technology: 99 7132-7142.

Flesch, T.K., R.L. Desjardins \& D. Worth, D (2011). Fugitive methane emissions from an agricultural biodigester. Biomass and Bioenergy 35, 3927-3935. 
Fuente, C. de la, J.A. Alburquerque,, R. Clemente \& M.P. Bernal (2013). Soil C and N mineralisation and agricultural value of the products of an anaerobic digestion system. Biology and fertility of soils, 49, 313-322. DOI: 10.1007/s00374-012-0719-9

Garg R.N., H. Pathak, D.K. Das \& R.K. Tomar (2005). Use of fly ash and biogasslurry for improving wheat yield and physical properties of the soil. Environmental Monitoring \& Assessment: 107 1-9

Geel, W. van \& W. van Dijk (2013). Toepassing van digestaat in de landbouw: bemestende waarde en risico's, Deskstudie in het kader van Energierijk, PPO nr. 565

Geel, W. van, J. de Haan \& H. Verstegen (2010). Gebruik van varkensdrijfmestdigestaat in de akkerbouw. Verslag van een vierjarige demo, uitgevoerd binnen het project Nutriënten Waterproof op Vredepeel. Project 32530133 10, PPO-AGV, Lelystad, 26 p

Geel, W. van, J. de Haan, M. Hanegraaf \& R. Postma (2019). Doorontwikkeling classificatieschema organische-stofrijke meststoffen. Deskstudie in het kader van de PPS Beter Bodembeheer / Effecten van organische stof. Wageningen Research | Open Teelten, Lelystad. Rapport WPR-project 3750384500, $58 \mathrm{pp}$.

Goberna, M., S. Podmirseg, S. Waldhuber, B. Knapp, C. GarcÃa \& H. Insam (2011). Pathogenic bacteria and mineral $\mathrm{N}$ in soils following the land spreading of biogas digestates and fresh manure. Applied soil ecology, 49, 18-25. doi: 10.1016/j.apsoil.2011.07.007

Groenestein, C.M., J. Mosquera \& R.W. Melse (2016). Methaanemissie uit mest : schatters voor biochemisch methaan potentieel (BMP) en methaanconversiefactor (MCF). Wageningen : Wageningen Livestock Research, (Livestock Research rapport 961).

Groenestein, C.M., R.W. Melse, J. Mosquera \& M. Timmerman (2020). Effect mestvergisting op de emissies van broeikasgassen uit mest van melkvee / een literatuur- en scenariostudie. Wageningen Livestock Research. Rapport 1235.

Groth, A., C. Maurer, M. Reiser \& M. Kranert (2015). Determination of methane emission rates on a biogas plant using data from laser absorption spectrometry. Bioresource Technology 178, 359-361.

Haan, J.J. de (2007). Digestaat. Voor u en het milieu het beste resultaat, http://edepot.wur.nl/28917

Handboek Bodem en Bemesting:

https://www.handboekbodemenbemesting. $\mathrm{nl} / \mathrm{nl} /$ handboekbodemenbemesting/Handeling/Organischestofbeheer/Effecten-organische-stofbeheer-op-bodemleven-en-structuur.htm

Hanegraaf, M.C., H.G.M. van den Elsen, J.J. de Haan \& S.M. Visser (2019).

Bodemkwaliteitsbeoordeling van landbouwgronden in Nederland - indicatorset en systematiek, versie 1.0. Wageningen Research, Rapport WPR-795. DOI: https://doi.org/10.18174/498307

Haveman E. (2014). Afstudeerverslag. Monomestvergisting: een stap naar een duurzame toekomst

Hrad, M., M. Piringer \& M. Huber-Humer (2017). Quantification of methane emissions from anaerobic digestion plants using laser absorption spectroscopy and inverse dispersion modelling. Proceedings Sardinia 2017 / Sixteenth International Waste Management and Landfill Symposium/ 2 - 6 October 2017, S. Margherita di Pula, Cagliari, Italy.

Hilhorst, G.J. \& A.J. Bos (2016). Stikstofwerking Organische Stof. Resultaten Bemestingsproeven Praktijknetwerk Microvergisting, https://www.verantwoordeveehouderij.nl/nl/VerantwoordeVeehouderij-2/rundvee/Digestaat-kent-hogere-stikstof-werkingscoefficient.htm

Hjort-Gregersen, K. (2014). Methane emission from Danish biogas plants. Economic Impact of Identified Methane Leakages. Project: ForskEl 2013-1-12093. 
Hoek, K.W. van der, M.W. van Schijndel, \& P.J. Kuikman (2007). Direct and indirect nitrous oxide emissions from agricultural soils, 1990-2003. Background document on the calculation method for the Dutch NIR. RIVM report 680125003; MNP report 500080003. Bilthoven.

Hoeksma, P., F.E. de Buisonjé, P.A.I. Ehlert \& J.H. Horrevorts (2011). Mineralenconcentraten uit dierlijke mest. Monitoring in het kader van de pilot mineralenconcentraten. Wageningen UR Livestock Research, Rapport 481, 74 p.

Holmgren, M.A. (2012). Sammanställning av mätningar inom frivilligt åtagande 2007- 2012 (Compilation of measurement results within the voluntary agreement 2007-2012). Avfall Sverige U2012:15, Malmö, 2012.

Houwelingen, K.M. van \& T.J.A. Gies, (2017). Bemestingsproef digestaat op veen; Het vaststellen van de $\mathrm{N}$-werking van onvergiste en vergiste mest en varianten van de vergiste mest via een veldproef op veengrond bij Kennis Transfer Centrum (KTC) te Zegveld. Wageningen, Wageningen Environmental Research, Rapport 2804. 18 blz.; 2 fig.; 8 tab.; 2 ref.

Insam, H., M. Gómez-Brandón \& J. Ascher (2015). Manure-based biogas fermentation residues Friend or foe of soil fertility?. Soil Biology \& Biochemistry: 84 1-14. DOI:

10.1016/j.soilbio.2015.02.006

IPPC (2006). IPCC Guidelines for National Greenhouse Gas Inventories, Prepared by the National Greenhouse Gas Inventories Programme. H.S. Eggleston, L. Buendia, K. Miwa, T. Ngara \& K. Tanabe (Eds.). Published: IGES, Japan.

Janssen, B.H. (1984). A simple method for calculating decomposition and accumulation of "young" soil organic matter. Plant \& Soil 76, p. 297-304.

Johansen, A., M.S. Carter E.S. Jensen H. Hauggard-Nielsen \& P. Ambus (2013). Effects of digestate from anaerobically digested cattle slurry and plant materials on soil microbial community and emission of CO2 and N2O. Applied Soil Ecology: 63 36-44. DOI: 10.1016/j.apsoil.2012.09.003

Kasper, G.J. \& A. Kemperman (2015). Mestvergisting Fermtech systems en Ecobag; Wageningen, Wageningen UR (University \& Research centre) Livestock Research, Livestock Research Rapport 874.

Koopmans, N., M. van Agtmaal \& N. van Eekeren (2018). Quick scan mest en bodemkwaliteit: invloed van mest en compost op de bodemkwaliteit, gewasproductie en emissies. Louis Bolk Instituut. Publicatienummer 2018-008 LbD

Kuikman, P.J., J.J.H. van den Akker \& F. de Vries (2005). Emissions of N2O and CO2 from organic agricultural soils. Alterra report 1035-2. Alterra, Wageningen

Lagerwerf, L.A., A. Bannink, C. van Bruggen, C.M. Groenestein, J.F.M. Huijsmans, J.W.H. van der Kolk, H.H. Luesink, S.M. van der Sluis, G.J. Velthof \& J. Vonk (2019). Methodology for estimating emissions from agriculture in the Netherlands: Calculations of $\mathrm{CH} 4, \mathrm{NH} 3, \mathrm{~N} 2 \mathrm{O}, \mathrm{NOx}, \mathrm{NMVOC}, \mathrm{PM} 10$, PM2.5 and CO2 with the National Emission Model for Agriculture (NEMA), Update 2019. Source Wageningen: Statutory Research Tasks Unit for Nature \& the Environment (WOt technical report 148).

Liebetrau, J., T. Reinelt, J. Clemens, C. Hafermann, J. Friehe \& P. Weiland (2013). Analysis of greenhouse gas emissions from 10 biogas plants within the agricultural sector. Water Sci. Technol., vol. 67, pp. 1370-1379.

Loria, E. R., J.E. Sawyer (2005). Extractable soil phosphorus and inorganic nitrogen following application of raw and anaero- bically digested swine manure. Agron. J. 97, 879-885.

Lukehurst, C.T., P. Frost \& T. Al Seadi (2010). Utilisation of digestate from biogas plants as biofertilizer. IEA Bioenergy 
Maldaner, L., C. Wagner-riddle, A.C. Vanderzaag, R. Gordon \& C. Duke (2018). Methane emissions from storage of digestate at a dairy manure biogas facility. Agricultural and Forest Meteoroly: $25896-$ 107. DOI: $10.1016 /$ j.agrformet.2017.12.184

Martin J.H. (2008). Methane to markets: international guidance for quantifying and reporting the performance of anaerobic digestion systems for livestock Manures. EPA, Contract No. EP-W-07-067.

Möller, K. \& T. Müller (2012). Effects of anaerobic digestion on digestate nutrient availability and crop growth: A review, Eng. Life Sci. 2012, 12, No. 3, 242-257

Mosquera, J., R. Schils, K. Groenestein P. Hoeksma, G. Velthof \& E. Hummelink (2010). Emissies van lachgas, methaan en ammoniak uit mest na scheiding. Wageningen UR Livestock Research, Rapport 427, Wageningen, $38 \mathrm{p}$.

NIR (2016). Austria's National Inventory Report 2016 Submission under the United Nations Framework Convention on Climate Change and under the Kyoto Protocol.

Nkoa, R. (2014). Agricultural benefits and environmental risks of soil fertilization with anaerobic digestates: a review. Agronomy for sustainable Development: 34 473-492. DOI:10.1007/s13593-0130196-z

Ovinge J. (2008). Biogas Flevoland 2005-2008 Eindrapport. Agro Milieu Coöperatie voor Boer \& Bodem, Lelystad, $53 \mathrm{p}$.

Parham J.A., S.P. Deng, H.N. Da, H.Y. Sun \& W.R. Raun (2002). Long-term cattle manure application in soil II. Effect on soil microbial populations and community structure. Biology and fertility of Soils: 38(4):209-215.

PPO, (Praktijkonderzoek Plant \& Omgeving B.V) (2007). Digestaat, voor u en het milieu het beste resultaat, ppt presentatie, 8 pagina's, http://edepot.wur.nl/28917.

Podmirseg, S.M., S. Waldhuber, B.A. Knapp, H. Insam \& M. Goberna (2019). Biology and Fertility of Soils: 55 (6) 565-576. DOI: 10.1007/s00374-019-01371-w

Reinelt, T., T. Clauß \& J. Liebetrau (2017). Monitoring of methane emissions from biogas plants. Gas for energy Issue 2/2017.

Rietra, R.P.J.J. \& T.J.A. Gies (2015). Toepasbaarheid en effecten van bemesting met digestaat; Sluiten van mineralenkringloop in Groene Cirkels. Wageningen, Alterra Wageningen UR (University \& Research centre), Alterra-rapport 2664. 34 blz.; 4 fig.; 8 tab.; 70 ref.

Risberg, K., H. Cederlund, M. Pell, V. Arthurson \& A. Schnürer (2017). Comparative characterization of digestate versus pig slurry and cow manure - Chemical composition and effects on soil microbial activity. Waste Management: 61 529-538. DOI: 10.1016/j.wasman.2016.12.016

RVO (2015). Gras benutten als substraat voor vergisting; https://www.rvo.nl/sites/default/files/RVOPubl-Grasvergisting-webdoc-mei15_1_def.pdf

RVO (2019). Website Covergisting: https://www.rvo.nl/onderwerpen/agrarischondernemen/mestbeleid/mest/mest-bewerken-en-behandelen/covergisting. Last access 05-09-2019.

Schijndel van, M. \& S. Van der Sluis (2011). Emissiefactoren voor de berekening van directe lachgasemissies uit landbouwbodems en als gevolg van beweiding. Achtergrondnotitie bij de National Inventory Report 2011.

Schröder, J.J., D. Uenk \& G.J. Hilhorst (2007). Bemestingswaarde en milieu-effecten als functie van de verhouding van minerale en organische N-verbindingen in mest. Mestkwaliteitsproef De Markt 20022006. Rapport 159. Plant Research International, Wageningen, 134 p. 
Schröder, J.J., J.C. van Middelkoop, W. van Dijk \& G.L. Velthof (2008). Quick scan Stikstofwerking van dierlijke mest; actualisering van kennis en de mogelijke gevolgen van aangepaste forfaits. WOt-rapport 85, Wettelijke Onderzoekstaken Natuur \& Milieu, Wageningen.

Schröder, J.J. (2016). Notitie bemestingswaarde van digestaten, LTO-Commissie Bemesting Grasland en Voedergewassen, Wageningen, 2016

Šimon, T. E. Kunzová \& M. Friedlová (2016). The effect of digestate, cattle slurry and mineral fertilization on the winter wheat yield and soil quality parameters. Crop Research Institute, PragueRuzyně, Czech Republic. Plant, Soil and Environment: 61 (11) 522-527

Thomsen, I.K., A.R. Pedersen, T. Nyord,\& S.O. Petersen (2010). Effects of slurry pre-treatment and application technique on short-term N2O emissions as determined by a new non-linear approach. Agriculture, Ecosystems and Environment 136 227-235

Timmerman, M., H.J.C. van Dooren \& G. Biewenga (2005). Mestvergisting op boerderijschaal. ASG, divisie Veehouderij, Praktijkrapport Varkens 42, $34 \mathrm{p}$

Timmerman, M., P. Claessen\& G. Andre (2006). Praktijkproef covergisting van dierlijke mest met organische additieven op boerderijschaal. Praktijkonderzoek Veehouderij, Lelystad, projectnr. 139.0820.000, $17 \mathrm{p}$.

Veeken, A.H.M., V. de Wilde, G. Szanto \& H.V.M. Hamelers (2002). Passively Aerated Composting of Straw-Rich Organic Pig Manure. In: Microbiology of Composting / H. Insam, N. Riddech, S. Klammer (ed.). - Berlin, Germany : Springer-Verlag, 2002 - p. 607 - 621.

Velthof G.J., J. Mosquera, J. Huis in 't Veld \& E. Hummelink (2010). Effect of manure application technique on nitrous oxide emission from agricultural soils. Alterra report 1992, Wageningen, $74 \mathrm{p}$

Velghe, F. en I. Wierinck (2013). Evaluatie van de vergisters in Nederland, Fase II, 136 p.

Velthof, G.L. \& J. Mosquera, (2011). Calculation of nitrous oxide emission from agriculture in the Netherlands. Update of emission factors and leaching fraction. Alterra report 2151. Alterra, Wageningen.

VERORDENING (EU) 2019/1009 VAN HET EUROPEES PARLEMENT EN DE RAAD van 5 juni 2019 tot vaststelling van voorschriften inzake het op de markt aanbieden van EU-bemestingsproducten en tot wijziging van de Verordeningen (EG) nr. 1069/2009 en (EG) nr. 1107/2009 en tot intrekking van Verordening (EG) nr. 2003/2003), Publicatieblad van de Europese Unie L 170/1

VLACO (2012). Ecologische en economische voordelen digestaat, Vlaamse Compostorganisatie vzw (VLACO), Mechelen

Voelkner, A. , Holthusen, D. \& Horn, R. (2015). Influence of homogenized residues of anaerobic digestate on the physicochemical properties of differently textured soils. Journal of Plant Nutrition and Soil Science: 178 (2) 261-269. doi:10.1002/jpln.201400138

Vonk, J., S.M. van der Sluis, A. Bannink, C. van Bruggen, C.M. Groenestein, J.F.M. Huijsmans, J.W.H. van der Kolk, L.A. Lagerwerf, H.H. Luesink, S.V. Oude Voshaar \& G.L. Velthof (2018). Methodology for estimating emissions from agriculture in the Netherlands - update 2018. Calculations of $\mathrm{CH}_{4}, \mathrm{NH}_{3}$, $\mathrm{N}_{2} \mathrm{O}, \mathrm{NO}_{x}, \mathrm{PM} 10, \mathrm{PM} 2.5$ and $\mathrm{CO}_{2}$ with the National Emission Model for Agriculture (NEMA). WOttechnical report 115. Wageningen UR. https://doi.org/10.18174/443801

Wellinger, A., J.D. Murphy \& D. Baxter (Eds.) (2013). The Biogas Handbook- Science, Production and Applications, Woodhead Publishing Limited DOI: 10.1533/9780857097415.2.302 
Westerkamp, T., T. Reinelt, K. Oehmichen, J. Ponitka \& K. Naumann (2014). KlimaCH4 - Klimaeffekte von Biomethan (Climate effects of biomethane production). DBFZ Rep. 20. Available at: https://www.dbfz.de/fileadmin/user_upload/Referenzen/DBFZ_Reports/DBFZ_Report_20.pdf

Wright, P. (2011). Overview of Anaerobic Digestion Systems for Dairy Farms," Natural Resource, Agriculture and Engineering Service (NRAES-143), March 2001.

Wolf, U. (2014). Emission of NH3, N2O and CO2 following the application of differently treated digestates from biogas production. Technische Universiteit Braunschweig, Duitsland

Wolf, D. \& A. Scherello (2013). Messung der Methanemission an der Biogasanlage Einbeck mittels CHARM $®$ (Methane Emission Measurement at Biogas Plant Einbeck using CHARM $®$ ), in: Gwf Gas|Erdgas. München: Deutscher Industrieverlag $\mathrm{GmbH}, 2013$, p. 1-7

Xiao J, J. Zhu, S. Chen, R. Weibin \& C. Miller (2007). A novel use of anaerobically digested swine manure to potentially control soybean cyst nematode. J.Env. Sci. \& Health 42(6):749-757.

Zdanevitch, I., G. Masselot, S. Collet \& O. Bour (2009). "Étude de la composition du biogaz de méthanisation agricole et des émissions en sortie de moteur de valorisation," Ineris, Verneuil-enHalatte. 


\section{Bijlage 1. Samenstelling mestsoorten}

Tabel 12 Samenstelling digestaat en verschillen ten opzichte van onvergiste dierlijke mest op basis van diverse onderzoeken (uit Rietra et al., 2015, naar Möller \& Müller, 2012)

\begin{tabular}{|c|c|c|}
\hline Parameter & Gehalten & Verandering (absoluut) \\
\hline Drogestofgehalte (\%) & $1,5-13.2$ & $-1,5$ tot $-5,5$ \\
\hline Organische stofgehalte (\%dm) & $63,8-75,0$ & -5 tot -15 \\
\hline Stikstofgehalte (\% dm) & $3,1-14,0$ & 0 \\
\hline Stikstofgehalte $\left(\mathrm{g} \mathrm{N} \mathrm{kg}^{-1} \mathrm{fw}\right)$ & $1,20-9,10$ & \\
\hline Aandeel $\mathrm{NH}_{4}$ van $\mathrm{N}(\%)$ & 44-81 & +10 tot +33 \\
\hline Koolstofgehalte (\% dm) & $36,0-45,0$ & -2 tot -3 \\
\hline $\mathrm{C} / \mathrm{N}$ quotiënt & $3,0-8,5$ & -3 tot -5 \\
\hline Fosforgehalte (\% dm) & $0,6-1,7$ & \\
\hline Fosforgehalte $\left(\mathrm{g} \mathrm{kg}^{-1} \mathrm{fw}\right)$ & $0,4-2,6$ & 0 \\
\hline Aandeel water oplosbaar van totaal fosfor (\%) & $25-45$ & -20 tot 47 \\
\hline Kaliumgehalte $\left(\mathrm{g} \mathrm{kg}^{-1} \mathrm{fw}\right)$ & $1,9-4,3$ & \\
\hline Kaliumgehalte $\left(\mathrm{g} \mathrm{kg}^{-1} \mathrm{fw}\right)$ & $1,2-11,5$ & 0 \\
\hline Magnesiumgehalte $\left(\mathrm{g} \mathrm{kg}^{-1} \mathrm{fw}\right)$ & $0,3-0,7$ & 0 \\
\hline Calciumgehalte $\left(\mathrm{g} \mathrm{kg}^{-1} \mathrm{fw}\right)$ & $1,0-2,3$ & 0 \\
\hline Zwavelgehalte $\left(\mathrm{g} \mathrm{kg}^{-1} \mathrm{fw}\right)$ & $0,2-0,4$ & \\
\hline $\mathrm{pH}$ & $7,3-9,0$ & $+0,5$ tot +2 eenheden \\
\hline
\end{tabular}




\section{Bijlage 2 Ammoniak emissie tijdens mesttoediening}

Tabel 13 Cumulatieve $\mathrm{NH}_{3}-\mathrm{N}$ emissie tijdens mesttoediening in voor- en najaar van RDM, VDM, mais en de bijbehorende digestaten en de vaste en vloeibare fractie die verkregen wordt na mechanische scheiding. Mest werd handmatig toegediend op bouwland, op dezelfde manier als een sleufkouter, en na 21 uur ingewerkt. De periode van emissiemonitoring van $\mathrm{NH}_{3}$ was 6 dagen in het voor-en 5 dagen in het najaar. De waarden tussen haakjes zijn de standaarddeviatie zoals ingeschat op basis van een Monte Carlo simulatie (uit Wolf, 2014)

\begin{tabular}{|c|c|c|c|c|}
\hline & $\mathrm{N}$-toediening & $\mathrm{NH}_{3}$-verlies & $\begin{array}{l}\text { Verlies als \% } \\
\text { van } \mathrm{NH}_{3}-\mathrm{N} \\
\text { toegediend }\end{array}$ & $\begin{array}{l}\text { Verlies als \% } \\
\text { van } \mathrm{N} \text {-tot } \\
\text { toegediend }\end{array}$ \\
\hline Voorjaarsaanwending & $\mathrm{kg} / \mathrm{ha}$ & $\mathrm{kg} / \mathrm{ha}$ & & \\
\hline RDM & 250.4 & $12.3(1.7)$ & $9.5(1.3)$ & $4.9(0.7)$ \\
\hline RDM DUF & 255.6 & $10.4(1.5)$ & $7.6(1.1)$ & $4.1(0.6)$ \\
\hline DIG RDM & 257.1 & $17.2(1.5)$ & $13.3(1.1)$ & $6.7(0.6)$ \\
\hline DIG RDM DUF & 2503 & $14.9(1.3)$ & $10.9(1.0)$ & $5.9(0.5)$ \\
\hline VDM & 259.0 & $11.5(1.1)$ & $5.8(0.5)$ & $4.5(0.4)$ \\
\hline DIG VDM & 295.9 & $17.0(2.8)$ & $8.8(1.4)$ & $5.8(0.9)$ \\
\hline DIG M & 256.4 & $18.6(1.8)$ & $13.2(1.3)$ & $7.3(0.7)$ \\
\hline DIG M DUF & 243.9 & $17.9(2.5)$ & $11.1(1.6)$ & $7.4(1.0)$ \\
\hline Controle & - & $2.1(0.6)$ & - & - \\
\hline \multicolumn{5}{|l|}{ Najaarsaanwending } \\
\hline RDM & 94.2 & $0.8(0.5)$ & $2.1(1.2)$ & $0.9(0.5)$ \\
\hline RDM DIF & 74.0 & $1.5(0.3)$ & $32.8(7.5)$ & $2.0(0.5)$ \\
\hline DIG RDM & 93.8 & $3.4(0.5)$ & $7.3(1.2)$ & $3.6(0.6)$ \\
\hline DIG RDM DIF & 83.2 & $4.1(0.4)$ & $21.5(2.3)$ & $4.9(0.5)$ \\
\hline VDM & 94.3 & $1.1(0.2)$ & $1.7(0.3)$ & $1.2(0.2)$ \\
\hline DIG VDM & 97.3 & $1.6(0.2)$ & $1.8(0.2)$ & $1.6(0.2)$ \\
\hline DIG M & 99.7 & $5.8(0.8)$ & $9.1(1.2)$ & $5.8(0.8)$ \\
\hline DIG M DIF & 85.8 & $3.6(0.5)$ & $15.3(2.0)$ & $4.1(0.5)$ \\
\hline Controle & - & $0.3(0.2)$ & - & - \\
\hline
\end{tabular}

RDM: rundveedrijfmest, VDM: varkensdrijfmest, M: mais ; DIG: digestaat d; DUF: dunne fractie; DIF: dikke fractie 



\section{Bijlage 3 Overzicht veldexperimenten in Nederland met digestaat van rundveedrijfmest en varkensdrijfmest}

Tabel 14 Veldexperimenten

\begin{tabular}{|c|c|c|c|c|c|c|c|c|c|}
\hline$M / C$ & Beschrijving & Locatie & Bron mest & $\begin{array}{c}\text { Gras/ } \\
\text { bouwland }\end{array}$ & Grondsoort & Duur & Toevoeging & Verschil & Referentie \\
\hline$M$ & $\begin{array}{l}\text { Praktijkonderzoek van de } \\
\text { Animal Sciences Group voor } \\
\text { LNV }\end{array}$ & Leeuwarden & $\begin{array}{c}\text { Vij Bosma Zathe in } \\
\text { Goutum (RDM) }\end{array}$ & Gras & $\begin{array}{c}\text { Zware jonge } \\
\text { zeeklei }\end{array}$ & $x^{2}$ & $\begin{array}{l}15 \text { en } 30 \text { ton/ha onvergist } \\
\text { en } 15+30 \text { ton/ha vergist. } \\
\text { Met stikstofniveau } 40-\text { of } \\
80 \mathrm{~kg} \text { stikstof uit } \\
\text { kunstmest of drijfmest. }\end{array}$ & $\begin{array}{c}16-18 \text { ton/ha geen } \\
\text { significant verschil tussen } \\
\text { stikstoflevering van } \\
\text { onvergist dan wel vergiste } \\
\text { mest. Bij } 30-33 \text { ton } \\
\text { significant hogere } \\
\text { stikstofopbrengst bij de } \\
\text { eerste snede. }\end{array}$ & $\begin{array}{l}\text { De Boer } \\
\text { (2004) }\end{array}$ \\
\hline C & $\begin{array}{c}\text { Veldproef } \\
\text { bedrijfssystemenonderzoek } \\
\text { Nutriënten Waterproof (NWP) }\end{array}$ & Vredepeel & $\begin{array}{c}\text { Proefboerderij } \\
\text { Vredepeel (VDM) }\end{array}$ & $\begin{array}{l}\text { Akkerbouw } \\
\text { (aardappel, } \\
\text { suikerbieten en } \\
\text { snijmais) }\end{array}$ & zand & $\begin{array}{c}2006- \\
2009\end{array}$ & Digestaat VDM & $\begin{array}{c}1^{\text {ste }} \text { jaarsstikstof in VDM is } \\
\text { hoger in digestaat dan in } \\
\text { ruw VDM. } \\
\text { Aardappel }+4 \text { ton/ha } \\
\text { Suikerbiet: nadelig effect } \\
\text { op hoge } N \text { gift jaar } 1 . \\
\text { Snijmais: }+1.2 \text { ton ds/ha }\end{array}$ & $\begin{array}{c}\text { Geel et al. } \\
\text { (2010) }\end{array}$ \\
\hline
\end{tabular}




\begin{tabular}{|c|c|c|c|c|c|c|c|c|c|}
\hline$M / C$ & Beschrijving & Locatie & Bron mest & $\begin{array}{c}\text { Gras/ } \\
\text { bouwland }\end{array}$ & Grondsoort & Duur & Toevoeging & Verschil & Referentie \\
\hline$M$ & Mestkwaliteitsproef & Hengelo & De Marke & Gras & zand & $\begin{array}{l}2002- \\
2006\end{array}$ & $\mid \begin{array}{c}0-300 \mathrm{~kg} \mathrm{~N} \text { tot/ha/j. P en } \mathrm{K} \\
\text { verschillen werden } \\
\text { gecompenseerd. }\end{array}$ & $\begin{array}{l}\text { Vergiste mest toedienen } \\
\text { geeft een hogere } \mathrm{N}- \\
\text { werking van } 64 \% \text { in jaar } \\
1 \text { en } 73 \% \text { na } 4 \text { jaar. } \\
\text { Opbrengstverschillen } \\
\text { nivelleerden na meerdere } \\
\text { jaren toediening }\end{array}$ & $\begin{array}{c}\text { Schröder et } \\
\text { al. (2007) }\end{array}$ \\
\hline C & Biogas Flevoland & $\begin{array}{l}\text { Lelystad en } \\
\text { Dronten }\end{array}$ & $\begin{array}{l}\text { RDM van: Van } \\
\text { Nieuwenhuyzen, } \\
\text { Nij Bosma Zathe } \\
\text { en Siebenga }\end{array}$ & $\begin{array}{c}\text { Akkerbouw (poot- } \\
\text { en } \\
\text { consumptieaardap } \\
\text { pelen, zaaiuien en } \\
\text { snijmais) }\end{array}$ & klei & $\begin{array}{l}2006- \\
2007\end{array}$ & 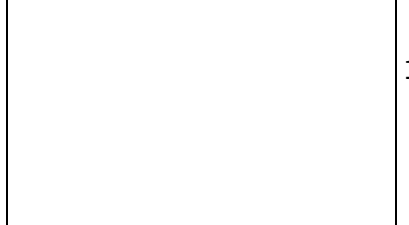 & $\begin{array}{c}\text { stikstofwerking digestaat } \\
10 \text { tot } 15 \% \text { hoger dan die } \\
\text { van gewone RDM }\end{array}$ & $\begin{array}{l}\text { Ovinge } \\
(2008)\end{array}$ \\
\hline M & Groene cirkels & Zegveld & $x^{2}$ & Gras & Veen & 2016 & $\begin{array}{c}\text { Veldproef als opvolging van } \\
\text { literatuurstudie Rietra et al } \\
\text { (2015). Er is niet gekeken } \\
\text { naar } \\
\text { bodemvruchtbaarheid. } \\
\text { Er is kunstmest ( } 27 \& 45 \\
\mathrm{kgN} / \mathrm{ha} \text { ), drijfmest ( } 15 \text { en } \\
25 \mathrm{~m}^{3} / \mathrm{ha} \text { ) en digestaat ( } 15 \\
\& 25 \mathrm{~m}^{3} / \mathrm{ha} \text { en } 1: 1 \text { verdund } \\
\text { (30 \& } 50 \mathrm{~m}^{3} / \mathrm{ha} \text { ) } \\
\text { opgebracht. }\end{array}$ & $\begin{array}{c}0.3 \text { ton hogere DS bij } \\
\text { digestaat met water. } \\
1-20 \% \text { meer } \\
\text { stikstofopname bij } \\
\text { digestaat, met water } \\
\text { verdund zelfs } 29-37 \%\end{array}$ & \begin{tabular}{|c|} 
(opvolging \\
voor Rietra \\
et al. \\
(2015)). \\
Houwelingen \\
en Gies \\
(2017)
\end{tabular} \\
\hline M & $\begin{array}{c}\text { Praktijknetwerk } \\
\text { 'Microvergisting in de praktijk' }\end{array}$ & $\begin{array}{l}\text { Hengelo en } \\
\text { Well }\end{array}$ & $\begin{array}{c}\text { De Marke en Den } \\
\text { Eelder }\end{array}$ & Gras & $\begin{array}{c}\text { Zand (De } \\
\text { Marke) en klei } \\
\text { (Den Eelder) }\end{array}$ & $\begin{array}{l}2015- \\
2016\end{array}$ & $\begin{array}{l}\text { Onvergist en digestaat } 30 \\
\text { kuub digestaat, en } \\
\text { verdunde digestaat }(+15 \\
\text { kuub water }\end{array}$ & $\begin{array}{c}23 \% \text { toename } \\
\text { stikstofwerking bij } \\
\text { digestaat (verdund zelfs } \\
40 \%)\end{array}$ & $\begin{array}{l}\text { Hillhorst en } \\
\text { Borst (2016) }\end{array}$ \\
\hline
\end{tabular}



Correspondentie adres voor dit rapport: Postbus 430

8200 AA Lelystad

T 0320291111

www.wur.nl/plant-research

Rapport WPR-840
De missie van Wageningen University \& Research is 'To explore the potential of nature to improve the quality of life'. Binnen Wageningen University \& Research bundelen Wageningen University en gespecialiseerde

onderzoeksinstituten van Stichting Wageningen Research hun krachten om bij te dragen aan de oplossing van belangrijke vragen in het domein van gezonde voeding en leefomgeving. Met ongeveer 30 vestigingen, 5.000 medewerkers en 10.000 studenten behoort Wageningen University \& Research wereldwijd tot de aansprekende kennisinstellingen binnen haar domein. De integrale benadering van de vraagstukken en de samenwerking tussen verschillende disciplines vormen het hart van de unieke Wageningen aanpak. 